\title{
LA DECADENCIA DE LAS REALES SOCIEDADES DE AMIGOS DEL PAIS
}

\author{
A la memoria de Alvaro del Valle Lersundi, hombre de \\ bien y espejo de amigos, Director de la Sociedad Económica \\ Bascongada, quien con tanta ilusión fomentó las investigacio- \\ nes y estudios sobre los Amigos del País.
}

Enterado el Rey por fuentes que no se revelaron, de que muchas Sociedades arrastraban una vida lánguida, de que otras habían cesado del todo de celebrar juntas, de que no pocas de ellas se debatían en medio de grandes apuros económicos, encargó al Consejo de Castilla, por R. O. de 28 de junio de 1786 , le propusiese los medios prudentes y efectivos para animar aquellos Cuerpos Patrióticos.

Con el fin de establecer un diagnóstico seguro antes de sugerir soluciones, organizó el Consejo una encuesta general, enviando sistemáticamente a cada una de las 45 Sociedades entonces existentes, una circular fechada en 14 de julio de 1786. En ella, no aludía a la crisis financiera que padecían casi todas, pero insistía en cambio en la falta de interés de los socios que dejaban de concurrir a las juntas y en la tibieza que manifestaban en el desempeño de las tareas del Instituto. Preguntaba en segundo lugar qué 
medidas serian conducentes para despertar la afición de los buenos ciudadanos y si la perpetuidad del empleo de Director sería una de ellas.

Pero no basta este breve resumen. Dada la importancia de la indagación y de las respuestas que originó, creemos que merece citarse in extenso el texto de la Circular, por cierto, no muy largo:

Señor Direclor de la Sociedad Económica de...

"Propenso siempre el únimo del Rey a promover las artes y oficios y fomentar la agricultura por las grandes utilidades que de su aumento resultan a sus vasallos y al Estado en gencral, ha mirado como uno de los medios más propios a este fin, el establecimiento de las Sociedades Económicas erigidas en varios pueblos y provincias del Reyno, y por esto ha dispensado a todos su Real protección.

Correspondiendo estos Cuerpos Patrióticos a los fines de su instituto, se dedicaron desde lucgo a promover las artes, oficios, la agricultura y la industria, dando pruebas narla equivocas de su utilidad en beneficio común y particular de los pueblos.

De aquí provino que, entexado S. M. de escos importantes progresos, mandase recomendar, como se hizo en su Real nombre, a los Prelados, Comandantes Generales y Justicias del Reyno que promoviesen los expresados Cuerpos Económicos, ofreciendo al mismo tiempo, atender a los individuos que más se distinguiesen en sus tareas en beneficio público.

Con efecto, recibió S. M. por algún tiempo gustosas noticias de los favorables efectos que producían dichas Sociedarles y quedó persuadido su Real únimo de la importancia de estos establecimientos. Pero ahora sabe, a pesar de sus deseos y de los estímulos con que quiso excitar la aplicación de los Socios, que se van desvaneciendo las fundadas esperanzas que prometian en beneficio de los pueblos y aun del Estado en general, porque se nota alguna decadencia originada sin duda de los partidos que se han formado, destructivos de la buena harmonía y correspondencia que debe haber entre unos mismos compatriotas, y que al mismo tiempo embarazan el curso a las buenas ideas y adelantamientos.

De aqui es que, entre tantos pueblos como se han erigido, se hallan muy pocos miembros que ejerciten sus talentos en utilidad común: y deseoso S. M. de animar semejantes establecimientos; para que sus operaciones produzcan a la causa pública las indicadas utilidades, ha encargado al Consejo en Real orden de 28 de junio próximo, que le proponga los medios prudentes y efectivos a licho fin.

Para desempeñar el Consejo esta confianza de S. M., ha resuelto que todas las Sociedades Económicas establecidas en estos Reynos informen de las causas y motivos de la decarlencia que se haya notado o note en cada una de ellas, así en la concurrencia de individuos a las Juntas, como en su tibieza al desempeño de las tareas de su instituto, proponiendo los me- 
dios que estimen pruchentes y efeetivos para aficionar a las jersonas celosas y arraigadas a estos establecimientos tan titiles a ln Monarquia, expresando si para ello será del caso la perpetuidad de los empleas de Directores, con lo demás que se les ofrociero y patccierc conducente a la debida instrueción de este asunto.

Y de erden del Consejo lo praticipo a V. S. a a fin de que, haeíndolo presente en esa Sociedad Económica, disponga su cumplimiento en la parte que le conrigroncle; y cn el interin me dará aviso del recibo de ésta a cfecto de ponerlo en su superior noticia.

Dios guarde a V. S. ${ }^{*}$ muchos años. Madrid, 14 de julio de $1786^{1}$.

Al ser recibida en las Sociedades, la circular - al parecer nada esperada- origina un gran revuelo. Los Amigos del Pais, asi de la Corte como de provincias, no ocultan su asombro, su disgusto y su disconformidad. $\mathrm{Al}$ gunos incluso se rebelan. Tal vez sea en ha matritense donde mejor se pueden captar las reacciones que provocó la iniciativa del Consejo. Ia primera de ellas fue una convocatoria a junta extraordinaria que se eursó a todos los socios de la Corle para el viernes 28 de julio the 1786. Los coneurrentes examinan prolijamente el texto del Consejo y coinciden en que se reduce a cuatro puntos cardinales:

- ¿Si ha habido decadencia, o si la hay?

- ¿Cuáles son las causas de la misma?

- ¿Con qué medios se puede subsanar?

- ¿Sería uno de ellos la perpetuidad del Director?

Ante todo, los Socios subrayan la importancia del problema planteado: se trata de un asunto por naturaleza largo, pero "no deben dar por perdido el tiempo que empleen en tomar todos los conocimientos necesarios y acordar con prudencia, madurez y detenida reflexión la respuesta y los términos en que debe concebirsen. En efecto, recalca el Censor que esto escribe, use trata, Señores, de la existencia o de la disolución de esta Sociedad y de todas las establecidas, pues aun cuando no se decrete formalmente la aboli-

1 Circular impresa, A. H. N., Consejos, leg. 3658/11, Expediente sobre la decadencia de las Sociedades Fconómicas de Amiggos del País. En adelante, cuando extractemos alguna cita sin dar mát referencia que un numbre de poblición se entenderả que procede do este legajo y que el nombre de ciudad a villa designa a la Sociedad Económicn alli instituida. Por cjemplo: Zamora significa: Sociedad de Zamora, A. H. N., leg. 3568/11. carpeta Zamora.

Gonzalos Anes en su estudio titulado "Coyuntura económica e Ilustraciön: Las Sociedades de Amigos del País», publicado en Econonía e Ilustración, Ediciones Ariel, Barce. lona, 1969, págs. 11-41, hace varias referencias a este legajo. 
ción de ellas, si las providencias del Gobierno no corresponden a lo que generalmente representa la Sociedad, no dudo en pronosticar su ruina, porque su existencia será tan lánguida, tan poco concurridas las juntas, tan sin actividad los trabajos que pueden considerarse como no existentes» ${ }^{2}$.

Pero hay más. Para los socios de la matritense que, con tanta abnegación, venían dedicándose al bien público, la circular constituye una flagrante injusticia, un agravio inmerecido. Los términos en que está redactada resultan “muy dolorosos» para el Cuerpo entero. Si hay alguna Sociedad acreedora a la gratitud del Rey y del pueblo español, que con derecho debe librarse de la censura de decadencia originada de partidos escandalosos y perniciosos, es la de Madrid, que ha servido de Norte y modelo para la formación de las demás y ha llevado una vida ejemplar. Hubiera merecido, pues, exceptuarse de la medida general «por su celo, aplicación, incremento, propagación de luces y conocimientos sólidos».

En muchas ciudades o villas de España, se hicieron sin duda semejantes reflexiones, aun cuando no nos queda constancia de ellas. A la primera insinuación del Consejo, contestó sólo la mitad aproximadamente de las Sociedades entonces erigidas, callando las otras, tal vez para manifestar así su descontento y desaprobación. La matritense, por su parte, esperó un año antes de dar su informe definitivo, pero recogió a finales de julio de 1786 los pareceres de sus tres Clases así como los de ciertos socios destacados. Veintidós, pues, fueron las que integraron el primer pelotón. Salvo error, la primera en contestar fue Lugo que lo hizo el 27 de julio, seguida de YEPES en 30 del mismo mes (fechas que no dejan lugar a una posible concertación con la célula madre) y la última del grupo fue GRAN CANARIA, cuyo informe se firmó en 31 de diciembre de 1786. He aquí la lista de las Sociedades que obedecieron la primera orden del Consejo:

$\begin{array}{ll}\text { Lugo } & 27-\text { VII-1786 } \\ \text { Yepes } & 30 \text {-VII-1786 } \\ \text { Requena } & 8 \text {-VIII-1786 } \\ \text { Osuna } & 12 \text {-VIII-1786 } \\ \text { Alaejos } & 22 \text {-VIII-1786 } \\ \text { Puerto Real } & 22 \text {-VIII-1786 } \\ \text { Toledo } & 22 \text {-VIII-1786 }\end{array}$

2 Arehivo de la S. E. M. (Sociedad Económica Matritense), leg. 79/10. Informe a la Real Sociedad sobre la circular que, en virtud de Real Orden remitió el Consejo a todas las Sociedades Económicas del Reyno sobre su decadencia y medios de que prosperen en beneficio público, Madrid, 2 de marzo de 1787, 9 folios. 


$\begin{array}{ll}\text { Sevilla } & \text { 26-VIII-1786 } \\ \text { Zamora } & \text { 26-VIII-1786 } \\ \text { Ciudad Real } & \text { 28-VIII-1786 } \\ \text { Lucena } & \text { 28-VIII-1786 } \\ \text { Jerez de la Frontera } & 13-\text {-X-1786 } \\ \text { Baeza } & 14-\mathrm{IX}-1786 \\ \text { Zaragoza } & 2 \text {-X-1786 } \\ \text { Vera } & 6-X-1786 \\ \text { Cuenca } & 7-X-1786 \\ \text { Vélez Málaga } & 17-X-1786 \\ \text { Oviedo } & 4-X I-1786 \\ \text { Santiago } & 13-X I-1786 \\ \text { Vergara } & 15-X I-1786 \\ \text { Valladolid } & 22-X I-1786 \\ \text { Tudela } & 15-X I I-1786\end{array}$

En vista de los muchos retrasos que advertía, el Consejo que, al parecer, concedía gran importancia a la información solicitada y reparaba en que varias entidades de las más destacadas (murcia, SEgovia, la MatriTENSE) no se habían manifestado todavia, envió a veinte Sociedades negligentes o refractarias un recuerdo ${ }^{4}$ en que repetía los términos de la primera circular, sin señalar fecha tope para la entrega de los informes.

Hecho curioso: la de mAdRid no figura entre las destinatarias de esa llamada al orden. Es de suponer que, por razones de proximidad o por contactos personales con los socios, estaba informado el Consejo de que LA MATRITENSE estaba preparando un abultado y circunstanciado expediente sobre este punto álgido.

Este «recuerdo», revelador del empeño del Consejo, no dejó de surtir efecto. Con inclusión de la de MADrid, que cerró el ciclo, contestaron en las fechas indicadas, 13 Sociedades más, a saber:

$\begin{array}{ll}\text { Gran Canaria } & 31-X I I-1786^{5} \\ \text { Granada } & 23-1 I-1787\end{array}$

3 Por lo visto, el informe de la Aragonesa, fechado en 2 de octubre de 1786, se extravió, pues no figura en la lista de los quo llegaron al Consejo antes del 8 tle enero de 1787. Recibió pues el recuerdo. La volvemos a colocar en el lugar que le corresponde normalmente por la fecha de su contestación.

4 A. H. N., Consejos, leg. 3658/11, carpeta Santander, donde hay ejemplar.

5 Aunque constestó Gran Canaria en 31-XII-1786, se le envió el recuerdo que se cruzó sin duda con su informe. 


$\begin{array}{ll}\text { San Clemente } & 11-\text { III-1787 } \\ \text { Santander } & 15-\text { III-1787 } \\ \text { León } & 16-\text { III-1787 } \\ \text { La Bañeza } & 23-\text { III-1787 } \\ \text { Soria } & 31 \text {-III-1787 } \\ \text { Baza } & 4-\text { V-1787 } \\ \text { Medina de Río Seco } & 23-\text { V-1787 } \\ \text { Sigüenza } & 23-\text { V-1787 } \\ \text { Segovia } & 16-\text { VI-1787 } \\ \text { La Gomera } & 6-\text { VII-1787 } \\ \text { Madrid } & 15-\text { VII-1787 }\end{array}$

Mantuvieron un mutismo absoluto otras siete Sociedades: ALMUÑ́́CAR, astorga, CHinchón, murcia, Sanlúcar de barrameda, talavera y TENERIFE ${ }^{6}$.

Los 35 expedientes recogidos se pasaron a la Junta de Recopilación que había de analizarlos y elevar sus conclusiones a la Superioridad. Estos informes que integran an voluminoso legajo ${ }^{7}$ son muy dispares: por su extensión, que varía de un folio incompleto a unos 15 ó más, en el caso de las Sociedades más arraigadas como LA ARAgonESA o LA MATRTENSE; por su contenido, a veces muy vago, teórico y retórico (JEREZ DE LA ERONTERA), otras veces muy preciso y técnico, ilustrado con cuadros y estadisticas (MADRID); por su tono, ya comedido y prudente, ya franco y directo, rayando en impertinencia (entre las que hablan "con desnudez deseuellan MADRID, SEGOVIA, TUDBLA y VALLADOLID); por la personalidad del redactor

Es de notar una anomalía. Quedaron olvidadas al parceer por completo algunas Sociedades importantes que no figuran para nada en el expediente, ni en los demás docu-

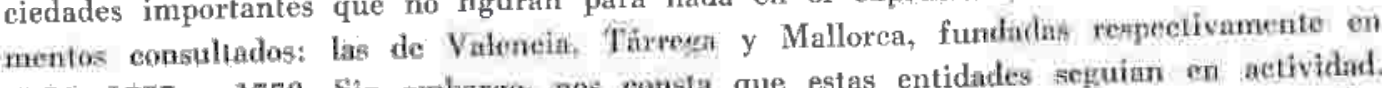
1776, 1777 y 1779. Sin embargo, nos consta que estas entidades seguian en actividad. Tampoeo fueron consultadas otxas Sociedades creadas anteriormente, convo por ejemplo: Plasencía (1780), Priego (1780). Montila (1780), Jaea (1783), Nrbancón (1784) y Bujolance (1785). Ein cunuto a Guadix (1785) y Ponferrada (1786), no hinhan remilido todavía sus estatutos, hecho que basta para explicar su exclasión de ta lista, mientras que las ausencias de Ecija y Benavente (abril y mayo te 1786) se teben a su erceción demasiado reciente.

7 Es el legajo 3658/11 ya citado, en folio, el que reúne esta importante documentación. Completamos la información de esta fuente básica con otros documentos del Archi. vo de la S. E. M. 
varios papeles llevan nombres ilustres: el conde de Villafuertes D. Germán de Salcedo, futuro marqués de Fuerte Hijar, D. Martín de Ulloa, el conde de Fuerteventura, el obispo de Cádiz, el marqués de Castrillo, el marqués de San Adrián, D. Arias Mon y Velarde, el marqués de Montehermoso, D. Josef Guevara Vasconcelos, D. Luis Marcelino Pereira D. Policarpo Sáenz de Tejada Hermoso.

\section{REACCIONES SUSCITADAS POR LA CIRCULAR}

Frente a la circular y a las insinuaciones que encierra, las Sociedades van a reaccionar de dos maneras: unas niegan rotundamente que hayan sufrido decadencia; otras, admitiendo en parte las críticas del Consejo, confiesan una decadencia más o menos acusada, aun cuando muchas veces pudieran alardear de realizaciones muy estimables. A este segundo grupo pertenecen unas Sociedades de creación reciente, no verdaderamente decadentes, pero que, por falta de tiempo u otras causas adversas, no llegaron al desarrollo que se podía esperar cuando se fundaron y también unos Cuerpos inertes y casi fantasmales, que por no haber podido cuajar, parecen incapaces de recobrar un soplo de vida ${ }^{8}$.

Pero, que nieguen o admitan la decadencia, todas las Sociedades incriminadas exponen para justificar su conducta y el nivel alcanzado lo que han hecho en los distintos ramos de su actividad o los obstáculos que encontraron en su carrera. Este haz de informes constituye pues una fuente insustituible para conocer desde dentro la historia de las Sociedades que existieron en el decenio transcurrido después de la erección de LA MATRITENSE, es decir entre 1775 y 1786.

Como se observa, en los distintos informes de las Sociedades una cierta uniformidad de pensamiontos y de renicdios sugeridos, puede uno preguntarse si la Matritenise no comunicó a sus afiliados do provincias las líneas esquemáticas de sus sespacstas, precisando sobre quó punlos habia que insistix particularmente. Un legajo de la S. E. M. (leg, 73/39) titulado atiotamen del Censor sobre las circulares de las Soctiedales Ecomanicas sabre las medios de hacerlas fomentar, desgraciadamente desaparecido hoy, deja tal vez suponer esta consulta previa.

8 Sobre la mayor o menor actividad, éxitos y fracasos y demás circunstancias de las corpontiones mencionadas a continuación, véase nuestro egtudio escrito en colnhoración con Frandisco Aguilar Piñal, Las Socieddules Económicas de Amigos del Pás en el siglo XVIII. Guia del investigador, Sar Scbastiann 1974, distributo por la Fundación Uni. versitaria Española, Alcalá 93, Madrid, 9. 


\section{A) Sociedades qué niegan la decadencia}

Esta es, por supuesto, la actitud que adopta la decana de las Sociedades, La bascongADa. No deja de ser algo condescendiente y tajante a la vez el tono de su contestación, cuando afirma: "Podría considerar que la R. O. no la concierne, pues tiene el estatuto de Academia y no sufre decadencia». Le basta con este aserto y no se rebaja a presentar la lista detallada de sus realizaciones, por estimar éstas harto conocidas. Su postura es no sólo digna, sino rígida, altiva y un tanto despectiva. Por mero patriotismo y para contribuir al bien público, se aviene a dar su dictamen sobre los puntos evocados por el Consejo. Lo hace con elevación de miras, pero sin contemplaciones, cuando critica e incluso acusa a los promotores de nuevas Sociedades y cuando propugna una reforma de las estructuras de las entidades ya existentes.

Si bien LA BASCONGADA escurre el bulto, asentando que el concepto de decadencia no dice con ella, otras dos Sociedades importantes (MADRID y zARAGOza), aunque rechazan de plano la acusación de una posible decadencia, consienten en discutir la especie, y exponen con gran lujo de detalles sus adelantos y sus tareas útiles a la patria. LA matritense, tal viez por ser matriz de todas las demás Sociedades, dejando aparte a LA BASCONGADA, iniciadora del movimiento, cree deber justificarse. Solicitando en juntas generales ordinarias y extracrdinarias el parecer de sus socios, pidiendo estudios y balances a sus tres clases, tarda un año cabal en allegar el material del expediente que quiere presentar a la Superioridad ${ }^{9}$. Como anteriormente señalamos, su informe fue el último que se remitió al Consejo, con fecha 15 de julio de 1787. Se conoce que para el Cuerpo Patriótico de la Corte, este asunto de la supuesta decadencia revistió suma

9 Varios informes sobre lo dechilmeia de las Sociertades ya no se encuentran en $\mathrm{d}$ Arehivo de ha S. F. M. Fultan loy el legajo $73 / 29$ que corresponde a un informe mandado por Zaragoy, sisi como el documento $73 / 40$ redactado por Jovellanos y Pérez Vi.

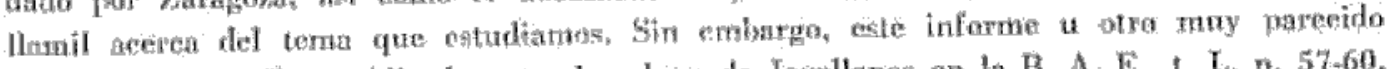
no está perdido. Fue putilicado entre las obreas do Jovellanos en la B. A. E., t. I. D. $57-60$. con el siguiente Lítula: Distamen que dio la clase de agricultars de la Sociedad Ecmómina de Madrid para evarun un informe pedido por cl Consejo Real sobre las causas de Lu decalenciu de pstos Cuerpos. Fechado en 3 de octubre da 1786 , va dirighido al Director

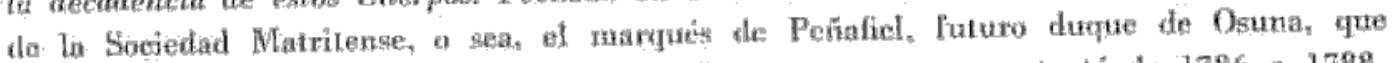

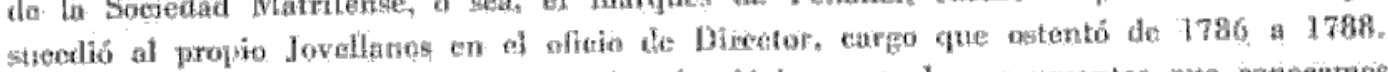
Et diotarnen de Joveltanos presenta, ordenado lógieanente los argumentos que conoevmos y'a y en varias veasiones incluso, al asturiano les conserva la formulaejón don que fue ron presentados por los distintos socios. 
importancia, de forma que puso los cinco sentidos en su contestación encaminada a demostrar al Consejo que respecto a ella, estaba en un error. “No ha habido decadencia en la Sociedad de Madrid, afirma un socio, el marqués de Alcocébar, y para demostrarlo, que se dé una noticia puntual de los trabajos de las clases desde su instituto» ${ }^{10}$. "Si alguna Sociedad ha merecido la censura que indica la R. O., la de Madrid está libre de los defectos que pudieran causarle este desaire... y que se represente a S. M. añadiendo que merece por su aplicación, celo e ilustración la confianza del Gobierno y la gratitud del público", sugiere el Censor. EI informe que redacta empieza por este aserto rotundo: «Lejos de haber decaído, nunca ha sido tan florecientes, idea nuevamente recogida en el párrafo que, no sin altivez, cierra este documento. "Por último, Señor, la Sociedad, atendida su constitución, ha hecho y hace todo el bien que puede al público y todo el que se ha debido esperar de sus facultades. No experimenta la decadencia que se supone, ni alimenta en su seno más partidos que el de la razón y las luces necesarias para la investigación de la verdad».

Antes de enumerar los resultados conseguidos, la matritense, sin falsa modestia, recalca su laboriosidad. No contenta con la junta de los sábados, prevista por los estatutos, ha creado otras tres cada semana para las clases de Agricultura, Artes e Industria. Además ha convocado sesiones extraordinarias en horas y días diversos, y juntas de comisiones que duraron a menudo de cuatro a seis meses continuos y se prolongaron hasta las once de la noche. Frecuentemente los individuos principian las tareas a las tres y las concluyen a medianoche. Por otra parte, la Sociedad no se lanza a ciegas a mejorar la vida económica del país. Reflexiona y medita largamente para fijar los principios de su acción y establecer un sistema y una doctrina coherentes y uniformes.

Así obra la Clase de Agricultura que se propone un objeto des gran trascendencia: descubrir las causas del atraso de su ramo, hallar los remedios apropiados para su restauración, conciliar la libertad «sin la cual nada prospera con las leyes que hacían inevitables los abusos; hacer feliz la suerte del campesino sin atentar a los derechos de la propiedad. Además quiere convertir la cría de ganados hasta entonees tan funesta al culkivo, en una fuente de auténtica riqueza para el país, declarar la guerra a la ignorancia y a las preocupaciones que ésta acarrea, y arrancar de raíz «unos males envejecidos que tenían su origen en la constitución misma, que fortificaban las leyes y que el tiempo había hecho habituales e incurables».

10 Arch. S. E. M., leg. $82 / 26,31$ de julio de 1786. 
Las primeras operaciones realizadas por los socios de aquella clase están reseñadas en el tomo $I$ de las Memorias del primer bienio, ya impresas, y en el segundo que está a punto de publiearse. Pero, desprovista de fondos y recursos para promover práctica y efectivamente la Agricultura, la Clase comprendió pronto que había de eonformarse con difundir las luces y conocimientos útiles por medio de memorias y escritos. Fn ello estaba metida cuando el Consejo le confió la elaboración del expediente sobre la delí cada y espinosa Ley Agraria, asunto que ocupó las juntas extraordinarias del año 77 al 79 , y que entonees sigue sobre el tapete. Paralelamente, no descuidaba las tareas que eran de su incumbeneia, despachando los informes que pedian el Ministerio y el Consejo, proponiendo y repartiendo premios. Acordó emprender la traducción de Moderato Columela, uPríncipe de los Geopónicos latinos", con la ayuda de varios individuos que trabajan con ahínco en ella, prestando un servicio señalado a la Nación y evengándola de la nota de perezas ${ }^{11}$.

Además, la misma Clase en el espacio de once años (1776-1787) dio 132 informes sobre obras remitidas a examen por el Rey y sus Consejos, de los que 26 corresponden al solo año 1786 , sin hablar de 15 cuctámenes referentes a memorias de socios. Por si esto fuera poco, la Clase estudió también todas las memorias aspirantes a los distintos premios de agrieultura que se concedieron a lo largo de los años. Este balance halagador justifica la cláusula con que acaba su exposición la sección de Agricultura: «No tiene pues, necesidad de remedio, porque na experimenta ningún mals.

Otro tanto puede decir la Clase de Industrix. Se expresa acon alguna mayor vehemencia» que su consocia, avisando que hablará ucon aquella noble libertad que debe reinar en todo pais donde ha establecido su imperio la filosofian. Empicza entonces por quejarse de la actitud del Gobierno cuya protección se ha reducido a «meros oficios de atención y urbanidad que momentáneamente estimulan por el placer que causa cualquier expresión dimanada del Trono, pero que hacen caer en un abatimiento e indolencia mucho mayor si se defraudan las esperamzas prudenteso ${ }^{12}$.

Después de este preámbulo, la Clase de Industria enumera sus tareas: cuida de las cuatro Escuelas Patrióticas para la enseñanza e hilado de lino, lana y algodón y de las de encajes, bordados y flores artificiales, que están

11 Ibidem, leg. 79/10, Informe del Censor de la Matritense, D. Joseph de Guevara Vasconcelos (véase nota 2).

12 Ibidem, idem. 
a cargo de socios curadores que las visitan diariamente y llevan las cuentas. Para premiar a 384 niñas acreedoras a una recompensa y equipar los nuevos talleres, ha costeado la compra de 456 tornos de hilar por un importe de 22.872 reales de vellón. Entre las alumnas aventajadas, ha repartido además 16.800 reales $(6.240$ de los cuales fueron donados por el arzolispo de Toledo). Se le deben varias creaciones de gran utilidad: un Montepío instalado en la Real Casa de los Desamparados para dar ocupación a la gente pobre, fundación en la cual se aprovechó el caudal de Temporalidades concedido por el Rey, asi como tres fábricas (de yeso de superior calidad, de velas de sebo, $y$ de jabones y polvos de olor). Ha dirigido y subvencionado experiencias con el carbón de piedra. Ha despachado entre 1776 y 1786, ambos inclusive, 129 expedientes remitidos por el Gobierno u otras autoridades, sin contar otros encargos de muy variada procedencia. Está de momento gestionando la compra de una máquina perfeceionada para hilar algodón, con el fin de construirla en España y difundirla en el Reino.

Su acción se ejerce también en múltiples direcciones: en el campo de la legislación, de la enseñanza técnica, de la beneficencia y hasta de las ideas. Citan los socios revueltamente el arreglo de las ordenanzas gremiales anticuadas, llevado con la colaboración estrecha de los mismos artesanos, la supresión del estanco y monopolio, la enseñanza metódica de aprendices y el establecimiento de clases de dibujo, de aritmética y geometria, la creación de almacenes de repuestos, de Montes Pios para socorrer a huérfanos y artesanos en sus enfermedades, la protección de talleres privados de su jefe. Pero su papel puede ser aún más sutil, más incitador cuando por ejemplo "procura inspirar la idea de que son necesarias las máquinas y descubrimientos que abrevian y abaratan las operaciones de las artes y en fin, combinar todos estos adelantos con la rutina y los contraprincipios políticos de que abundan las ordenanzas hechas en tiempos de ignorancia».

Las responsabilidades que han de asumir los socios en tan variados campos de la actividad humana, les obligan a meditar sobre el origen de las artes y la verdadera libertad estêtica. Así partiendo de realidades muy concretas, se elevan necesariamente, por la misma indole de lo que tienen entre manos, hasta una reflexión propiamente filosófica. Nada pues, en estas muy numerosas y diversificadas realizaciones, permite suponer el menor indicio de decadencia.

La Clase de Artes y Oficios se defiende de la acusación con argumentos parecidos: "No ha florecido nunca mâs que hoy». Huelga, pues, decir que no ha decaído, afirma su representante, D. Manuel Sixto Espinosa. El 
número de sesiones que celebró cada año fue casi continuamente en aumento. Pasó de 27 en 1776 a 55 en $1786^{13}$. La asistencia de socios a Ias juntas varió según los años entre 5 y 8, exceptuando los años 1776 y 1777 en que llegó a 10. En el espacio de seis años, la Clase extendió 130 infor. mes o estudios similares, 55 de los cuales fueron solicitados por el Consejo y tres encargados por R. O. en 1785 y 1786. Los demás se los pidió la Sociedad.

Entre las realizaciones que, en su opinión, destacan por su importancia, la Clase señala la reforma de ordenanzas de varias entidades o corporaciones que han ocupado sucesivamente su atención de 1777 a 1785: los diez Gremios que trabajan la madera, el Colegio de artífices plateros, los sastres de Madrid (cuyos estatutos constituyen un modelo particularmente acertado) y distintos gremios de fuera. Dos años de estudio asiduo la han puesto ya en condiciones de conocer cuál debería ser el régimen de policía conveniente, si se disolvieran enteramente los Gremios y se reuniesen en grandes Colegios aquellos que, siendo análogos por la naturaleza de sus actividades, se perjudican recíprocamente con sus respectivos privilegios.

La Clase de Artes y Oficios tiene en carpeta varios proyectos. Entre ellos el de fabricar en Madrid las herramientas que usan los artesanos españoles y que, hasta la fecha, se traían de Londres, Birmingham y Sheffield. Termina su alegato dando ejemplos concretos de los resultados alentadores que se han logrado en algunas industrias. Ya en los talleres de los artistas más famosos, merced a máquinas nuevas, se construyen hebillas de plata con tanta perfección como con los troqueles "y sin los riesgos del uso del volante), y se abrillantan las piezas de acero mejor de lo que hacen los Ingleses. En sus visitas a los talleres, los socios han adquirido la certeza de que se puede labrar en España el hierro y el acero tan bien o mejor que en Inglaterra. En fin, se estudia con sumo interés el medio de restablecer una industria relojera en España.

La conclusión que sacan los socios es netamente positiva: «Se puede decir de su Clase, que le ha sucedido lo que a los hombres, esto es que su vigor y sus luces se han aumentado con su edad y por consecuencia..., no ha experimentado decadencia» ${ }^{14}$.

13 1776: 27 juntas; 1777: $34 ; 1778: 34 ; 1779: 30 ; 1780: 39 ; 1781: 43 ; 1782: 36$; 1783: $42 ; 1784: 51 ; 1785: 55$.

14 Arch. S. F. M., leg. 82/26, Dictamen de D. Manuel Sixto Espinosa, Madrid, 31 de julio de 1786. 
Como se ve, cada una de las secciones de la matritense, al extender su informe particular, manifiesta cierta independencia respecto de las demás y una notable libertad de opinión y expresión. En su informe general, la Sociedad madrileña recogerá los pareceres de sus tres Clases, pero también añadirá datos y comentarios nuevos.

Saliendo al paso de las críticas que le dirige el vulgo, escribe: “No extraña la Sociedad que el público esté en el error y la haga, cuando no perjudicial, inútil, porçue ignora el secreto influjo que ha tenido en muchas providencias útiles». "Las luces de este Cuerpo han servido de Norte a las resoluciones del Gobierno y los informes solos dados al Consejo forman la más completa apología de la Sociedad» ${ }^{15}$. ¿Quién mejor que el Consejo de donde ha salido aquella flecha envenenada de su supuesta decadencia, conoce la labor agotadora e ímproba que lleva a cabo? Informa sobre todo, estudia más de cien asuntos de consideración al año y su Censor que hace de Fiscal del Cuerpo, lo lee todo, imponiéndose un trabajo muy superior a las fuerzas humanas. Además es permanente enlace con las Sociedades de provincias que la consultan a menudo.

Laboriosa, abnegada, LA MATritense es también dadivosa. En 1785, pasaron de 30.000 reales los que voluntariamente ofrecieron los marqueses de Peñafiel, D. José del Río, D. Francisco Cabarrús y otros individuos. El marqués de Castrillo cedió una finea suya para que la Sociedad hiciese ensayos de agricultura. D. Josef Almarza anticipó de sus caudales las crecidas cantidades que se necesitaban para la impresión de las Memorias del segundo bienio. Los oficiales de secretaria por su parte, costean los gastos de correspondencia y eseritorio. En cuanto a los curadores de escuelas, pagan a menudo de su bolsillo gratificaciones y premios. D. Josef Herreros, Comisario General de Cruzada, abona el alquiler de la escuela patriótica de su parroquia. El conde de Campomanes contribuye con sus trabajos literarios y considerables cantidades, mientras los comisionados cargan con todos los gastos ocasionados por los experimentos que dirigen. La Sociedad Matritense es una gran empresa de generosidad.

Y para que no subsista la menor duda en cuanto a su desbordante e incansable actividad, LA MATRITENSE concluye su informe recogiendo en un cuadro general el número de expedientes e informes que ha llevado a cabo desde 1775 hasta mediados de 1787. Se reparten como sigue:

15 Ibidem, leg. 79/10. 
Expedientes formados por Real Orden

Expedientes formados por Orden del Consejo

Expedientes formados para la Junta de Comercio

Informes sobre asuntos promovidos por la Sociedad

Memorias de socios

Memorias concurrentes a premios

\section{Total}

755

El recuento de tantos esfuerzos consentidos por el bien del Estado y la felicidad del pueblo, sugiere a la Sociedad, en vez de la lógica satisfacción, esta amarga reflexión: «De todos estos ejemplos de virtud patriótica, se hace gran aprecio en los países extranjeros, se publican en los papeles periódicos con ostentación, y en el nuestro no sólo quedan sepultados en un obscuro silencio, sino que en vez de agradecimiento, suelen tener por recompensa la crítica y la murmuración».

El mismo desencanto se refleja en el informe de la sociedad ARAGonESA y por los mismos motivos: tiene el sentimiento de que es víctima de una injusticia.

Tras recordar su erección en 1776 y sus numerosos y espectaculares éxitos, expresa su disconformidad: "Ha causado novedad y aún nesentimiento al pundonor y celo de estos socios que tanto se animan y trabajan... el que se haya informado a S. M., sin excepción, sobre el estado de las Sociedades... de que se van desvaneciendo las esperanzas que estos cuerpos benéficos prometían en utilidad de los pueblos y aun del Estado, porque se nota alguna decadencia originada de los partidos... En la Aragonesa, no ha habido partidos ni diferencias; antes bien se ha mantenido la mayor unión y nunca ha estado la Sociedad más concurrida y floreciente que de tres o cuatro años a esta parte... Lejos de observar en ella una decadencia, el testigo tendrá mucho que admirar de que en tan corto tiempo, sin dotación ni otros sufragios, ni fondos que los que voluntariamente suministran los socios, haya podido fundar y mantener tantas escuelas»...

La enumeración de lo hecho basta para manifestar que por su parte, ha excedido todas las esperanzas que el Soberano y sus ministros habían podido concebir de su fundación. Y concluye invitando al Consejo a que mida la distancia recorrida. Y en verdad, la lista de las operaciones de LA ARAGONESA da pie para la meditación y admiración, más aún cuando se sabe que lo conseguido se debe al trabajo constante y encarnizado de sólo 
algunos socios aplicados. No menos de siete escuelas especializadas ha proporcionado al público:

- una de Matemáticas que costea la Sociedad con aprobación del Rey.

- una de Agricultura, aprobada por el Consejo.

- una de Economía civil y de Comercio.

- una de Filosofía moral.

- una de Derecho público.

- una de Dibujo costeada por un socio y que ha tenido notorios adelantos.

_ una de hilar al torno las cuatro materias (lino, lana, algodón, seda).

Además, ha implantado una fábrica de hilar la seda según el método de Vaucanson, de la que han salido educadas, en 1786, 18 muchachas destinadas a radicar entre las mujeres esta industria ejercida hasta entonces por los hombres. Los cosecheros logran así 16 reales de sobreprecio en cada libra y los fabricantes se valen de ella para trabajar sus listonerias, cosa antes imposible, de modo que todos salen ganando.

La Sociedad reparte muchos premios entre su numeroso alumnado. Propone otros para promover extensas plantaciones de árboles, nuevas fábricas y diversos ramos de la agricultura, artes y oficios, comercio, ciencias exactas, etc..., no sólo en la capital, sino también en los trece corregimientos del reino. En Jaca y en Biescas, estableció sendas fábricas de estameñas y educó en Zaragoza a una maestra de hilar para abrir escuela en Jaca, fundando en esa ciudad una Junta vinculada a LA ARAgonesa hasta que se erigió en Sociedad independiente. En Calatayud, instaló una fábrica de lonas para aprovechar el mucho cáñamo que en esa comarca se cría, proyectando beneficiarlo en Daroca en vez de mandarlo a El Ferrol según la costumbre. Premió una fábrica de bayetones en Gera de Albarracín y varias plantaciones de árboles en Pedrola, Fuentes de Ebro y otros pueblos. Ha puesto talleres de caridad y escuelas gratuitas de niños y niñas en los pueblos de Peñaflor, Lanaja, Sós, y fomenta en unión con los monasterios de Cistercienses, Cartujos y otros regulares, establecimientos similares para la educación de los jóvenes. Su acción benéfica se extiende la toda la provincia.

En la misma capital, cré una Junta de caridad que en sus talleres ocupa a los muchachos pobres; abrió seis escuelas de niñas bien distribuídas en los distintos barrios, donde se enseñan las labores y los buenos modales y acopió grandes cantidades de lino, cáñamo y otras materias primas para dar trabajo a muchas tropas de mujeres «que antes mendigaban y ociaban». De resultas de estas medidas, el número de mujeres y niños que antes acudía cada dos dias a la sopa boba que se repartía a las puertas del 
Palacio episcopal, pasó de 1.800 a unas 200 escasas, reduciéndose también a proporción el número de hombres pordioseros.

Sin lugar a dudas, los socios de LA ARAgONESA que - conviene recordarlo- no percibían ningún estipendio y cuyo esfuerzo era absolutamente desinteresado, bien merecían el agradecimiento y el aplausos de la patria, y es evidente que la cireular del Consejo les hirió cruelmente.

Otras Sociedades menos destacadas que las anteriores rechazan también la nota de decadentes y manifiestan la misma buena conciencia, la misma legítima auto-satisfacción. Es el caso de valladolid que subraya escuetamente su creación reciente -fueron aprobados sus estatutos en 1784- y se otorga un satisfécit, afirmando que "ha hecho progresos inesperados en los ramos de su institutos. En efecto, en este breve lapso de tiempo consiguió crear tres escuelas para niñas (de hilado de lana, de costura, de bordados y otras labores) y está a punto de inaugurar otras dos de primeras letras, una de ellas establecida por orden Real.

En el campo de la agricultura, realizó un plantío de olmos negrillos de más de un cuarto de legua, de las puertas de Santa Clara hasta el camino de Cabezón y otro plantío de moreras en el Espolón. Asimismo hizo experimentos para aclimatar los gusanos de seda y por fin tiene sobre este tema un sinnúmero de proyectos que está meditando y madurando.

De igual modo, hace hincapié en su incansable actividad la Sociedad de Luco, casi coetánea de la anterior. Constituyen su hoja de servicios el fomento de las hilazas al torno, la mejora del blanqueo de lienzos, Ios plantíos de moreras y otros vegetales, la creación de fábricas, de una escuela de doctrina cristiana y primeras letras, la concesión de premios a las artes, inventos y memorias de mérito, y sobre todo el haber costeado el desagüe y desecación de una laguna vecina a la capital que la infestaba con sus miasmas y ocupaba un amplio terreno apto para plantar en él una alameda.

Granada, a su vez, defiende resueltamente su actuación corporativa y la conducta de sus socios. No hubo tibieza en sus empeños patrióticos, ni experimentó la menor decadencia en sus tareas constitutivas. Como prueba de ello, cita las realizaciones siguientes:

- una escuela de dibujo costeada por el garboso patriotismo de varios socios hasta que en virtud de sus comprobados adelantos, se sirvió el Rey admitirla bajo su protección y dotarla con dos mil ducados anuales de los sobrantes de los Propios. 
- los certámenes públicos que organiza regularmente y la concesión de premios y gratificaciones a educandos y artistas.

- el fomento de plantios de morales y moreras, principal fuente casi agotada de la riqueza de la provincia.

- el esfuerzo que hizo para conseguir la perfección en las labores de lana por medio de la escuela que erigió, hasta ver restablecida la manufactura de paños que sufría abandono.

Estos progresos, concluye la Sociedad granadina, y otros logrados en el último bienio, manifiestan que «este cuerpo patriótico mantiene su vigor primitivo».

\section{B) Sociedades que admiten una decadencia más o menos marcada}

Un segundo grupo de Sociedades _ el más nutrido-, reconoce que no ha tenido el desarrollo que sus fundadores y el público podian esperar. Humildemente, confiesan que la circular del Consejo no carece de fundamento y se catalogan entre las Sociedades decadentes. A pesar de sus esfuerzos dignos de alabanza, no se vanaglorian de sus éxitos. Otras, sea antiguas, sea demasiado recientes, o no han tenido tiempo de prosperar o no han podido, más por causa de condiciones adversas que por culpa suya. Otras, en fin, están en plena descadencia o inanimación, y no ver - 1 modo de remediarlo.

Gran canaria encabeza, por la importancia de sus realizaciones, este segundo grupo. Debido a su constitución volcánica, a su clima subtropical y atlántico, a la distancia que la separa de las provincias continentales, presentó la isla problemas muy peculiares para la Sociedad que se desarrolló en su suelo, aunque también compartió con el resto de España problemas generales de difícil resolución.

Su fundador fue el Padre Juan Bautista Servera, obispo de Canarias, promotor asimismo de la Sociedad de la isla de La Palma. Pocos campos de la actividad humana escaparon a la nueva Sociedad. Los redactores del informe nos hacen una prolija relación de lo que promovió e intentó. Erigió dos escuelas patrióticas para niñas pobres y mandó hacer el padrón de los niños desvalidos para darles la enseñanza competente y dedicarlos a trabajos útiles. Desterró la holgazanería y la mendiguez, habilitando edificios para recogimiento de vagos y socorro de mendigos necesitados. Creó la pesca del arenque y de la sardina. Obtuvo la libertad de impuestos para la pesca 
de la sama y del tarzate ${ }^{16}$ en las costas de Africa. En el ramo de Artes y Oficios, fomentó el curtido de peletería, contribuyendo al establecimiento de dos zapateros portugueses que trabajaban con toda perfección. Protegió la fábrica de sombreros bastos, consiguiendo se prohibiesen los extranjeros. Fomentó los tejidos de lana y de lino. Extendió el cultivo de la vid, mejoró los vinos y los plantíos de morales. Introdujo el cultivo del algodón, de las higueras y almendros. La Sociedad tenía otras muchas ideas, algunas de ellas sumamente nuevas, que la falta de medios le impidió llevar a cabo. Imitando a Olavide, formó el proyecto de poblar el Sur y el Poniente de la isla, destinando 24.000 pesos para fundar las tres primeras poblaciones. Imaginó organizar y sistematizar la pesca de la ballena que abundaba entonces en el Océano Atlántico. Quiso reconstruir los montes reducidos por unas talas irreflexivas e impedir unas roturaciones perjudiciales para la economía general de la isla. Pero encontró en su camino muchas cortapisas y obstáculos que desanimaron a los socios y retrajeron a muchos vecinos de ingresar en sus filas. Poco a poco fue perdiendo los bríos que había sabido renovar en ella el obispo D. Antonio de la Plaza que fue su director, y entró en decadencia. Y los firmantes resumen la situación en estos términos: “Es verdad notoria y constante que la falta de protección ha tenido a esta Sociedad en decadencia y a sus individuos en desaliento. En otros asuntos de interés y de beneficio público, no ha experimentado este Cuerpo el amparo y protección que necesitaba para conseguir sus fines).

Soria se defiende de las acusaciones de la circular diciendo: "No se han experimentado bandos ni facciones... porque siempre han observado sus individuos la buena armonía que exige su instituto, fijando la atención en sólo el objeto de mejorar la constitución del país por los medios más convenientes). Este afán desinteresado lo ha continuado con la mayor actividad hasta el día, logrando crear en la ciudad una fábrica de 28 telares para medias de estambre, de buenos tintes, unas tinas y prensas ne-

16 Sama $=$ rubiel o pajel común.

Tarzate, en realidad Tasarte, adesignación de la albacora (Thynus alalunga o Germo alalunga) en Arrecife...n. Albacora, pez de mar del orden de los Acantopterigios, lat. scomber, caballa. Véase Manuel Alvar, "La terminología canaria de los seres marinos», en Anucrio de Estudios Atlánticos, XXI (1975), págs. 425-8. Sobre la abundancia de esta especie que aún en el siglo XIX daba lugar a auténticas pescas milagrosas, véase D'Avezac. Iles de l'Afrique. Seconde partie. Iles africaines de l'Oéan Atlantique. Paris, 1848, pág. 147 (Collection l'Univers piltoresque). Agradecemos a nuestro amigo Alejandro Cioranescu, profesor de la Universidad de La Lguna, estas informaciones. 
cesarias para el feliz desarrollo de las fábricas de lana de la provincia. Estas iniciativas proporcionaron digna ocupación a un gran número de jóvenes de uno y otro sexo instruidos en las escuelas patrióticas creadas por la Sociedad en Soria y on la villa cie San Pedro [Manrique]. Y para no umolestary al Consejo, la Sociedad pasa por alto kotros progresos». Sin embargo, es cierto que disminuye la asistencia de los socios y segutirá disminuyendo «si no se les pone a la vista alguna demostración de la beneficencia que el Soberano tiene ofrecidas. El conde de Fuerteventura, Director de la entidad, que firma el informe con el Secretario Isidro Pérez, admite cierta decadencia, aunque agrega: «No hay otro modo de restituir este Cuerpo al estado foreciente que tuvo en sus principios».

En zamora, la situación es muy análoga: «Las juntas empezaron con bastante concurrencia, siguieron con menos y permanecen con pocos socios». Pero este retroceso no se puede achacar a desavenencias o formación de partidos en el Cuerpo, sino a "una especie de calma, nacida acaso de no poder admitirse muchos de los proyectos por falta de medios». Los pocos individuos que quedan mantienen con firmeza los ramos considerados como más útiles. La lahor docente de la Sociedad no resulta afectada: permanecen en actividad las escuelas de costura e instrucción de niñas, la de hilazas de lino al torno cuyos progresos se advertirán en los hilados que se destinan para la fábrica de San Ildefonso. La Escuela de dibujo sigue frecuentada por muchos jóvenes. La Clase de Agricultura consiguió unos éxitos notables, como el plantel de unos 90.000 olivos y otros tantos frutales en Fermoselle. Estos árboles ya producen frutos y se piensa en intensificar las plantaciones. Por otra parte, la Sociedad estudia los medios de crear una escuela de hilado abastecida por lana del país y de fomentar las artes y oficios. Tiene también en proyecto la formación de un hospicio y la recolección de los pobres. En resumidas cuentas, a pesar de sus limitaciones, alcanzó más o ménos la Sociedad de Zamora las principales meias que se propuso, pero la escasez de medios le obligó a reducir considerablemente sus pretensiones... «Aunque puede asegurarse que esta Sociedad no ha tenido notable decadencia respecto de los cortos ramos que abraza, es preciso confesar que sus fuerzas no alcanzan ni a Jas pruebas de otros que medita)s.

BAZA, aunque de creación muy reciente (1785) «ni sufre decadencia, ni ha hecho grandes progresos), escriben el Director y el Secretario que, muy metódicos, empiezan su informe por una Memoria de lo que se ha hecho. En realidad, peca por modestia, ya que en tan corto tiempo, sus realizaciones son notables. Ha fundado tres escuelas, dos gratuitas de primeras 
letras, para los niños pobres, en Baza y en la villa de Caniles, dotándolas con diversos premios, y otra de agricultura en la que se leen los mejores escritores. Su acción benéfica y social es también digna de encomio: ha creado un Fondo Pío de labradores, iniciativa muy aplaudida por la población, y contribuido con la ciudad al establecimiento de una Hermandad de caridad para socorrer a los verdaderos pobres y proporcionarles trabajo. En fin, es sumamente apreciable lo que hizo en el terreno económico. Supo despertar y alentar el celo y la emulación de los socios labradores, quienes en dos años plantaron más de 20.000 olivos, así como varios millares de frutales y árboles útiles. Consiguió del Rey un coto para los ganados. Inirodujo el uso del torno para lino y cáñamo y mandó fabricar 50 tornos que producen 2.000 varas de un hilo finísimo por cada onza. Si se añade que descubrió dos minas de carbón, que en sus juntas se pronunciaron varios discursos, que se distribuyeron premios en la Junta General de 1785 y que se prevé la entrega de otros el 30 de mayo de 1787 , se ve que la joven Sociedad de Baza prestó en el bienio de su existencia, cuanto servicio pudo a sus conciudadanos.

No deja de admirarnos también lo que logró la Sociedad «decadente» de osuna. Oficialmente erigida en 1780, experimentó grandes dificultades para arrancar y se suspendieron las juntas hasta el 16 de marzo de 1785, fecha en que empezó a funcionar. Lleva sólo, pues, un año de vida. Obtuvo del Gobierno la concesión de la iglesia y del colegio de los ex-jesuitas así como una contribución anual del duque de Osuna de 24.000 reales, sin contar varias limosnas circunstanciales. Agrupó hasta 60 socios. Creó una Casa de Orfandad donde se acogieron once niñas desamparadas, dos escuelas gratuitas de primeras letras, en la que 344 niñas y 312 niños están al cargo de cinco maestras y dos maestros, cuyo estipendio corre de cuenta de la Real Administración de las Salinas de la villa. La Sociedad formó los reglamentos de todos estos centros benéficos y docentes, así como del Hospicio de vagos, mendigos, mujeres y niños sin destino. En su seno, organizó comisiones de agricultura que entienden en el cerramiento de las tierras, y otras de arte, que formaron el padrón de los pañeros, cardadores, carpinteros y plateros para cuyo gremio se están labrando nuevas ordenanzas. En verdad, nos parece que la Sociedad ursaonense de Amigos del Páís iniciaba su carrera con buenos augurios.

Fundada hace poco (1784), PUERTo Real no está desprovista tampoco de cierto empuje prometedor. De momento, ha ceñido su esfuerzo al ramo de la industria, "pues este vecindario, en la mayoria, es sostenido del corto jornal que adquiere, y faltándole, perecen las familias enteras, 
mendigan, carecen de auxilio sus enfermedades y cometen reprensibles excesos, contrarios al servicio de Dios y del Rey». Con el apoyo del Alcalde Mayor y del Ayuntamiento, la Sociedad acopió varias porciones de lino que repartió entre las mujeres pobres del. pueblo, encantadas con esta inesperada ganancia. Hicieron hilazas y calceta, parte de las cuales se mandó a Nueva España. Para la formación y educación de las niñas, se estableció una escuela regentada por una maestra que difundió en ella el uso de los tornos. En 1786, contaba ya con 45 alumnas. Además, se construyeron varios telares y se fabricaron no pocas piezas de lienzos adecuados al consumo de la población, así como medias de seda. Se hizo, pues, algo positivo, aunque insuficiente. Su Director y fundador, el Obispo de Cádiz, D. Josef Escalzo y Miguel, recalca en el informe todos sus conatos por desterrar la ociosidad de aquella tierra “donde más está arraigada la desidia y el vicio». «Me desconsuela sobremanera, confiesa, el ver que hay fiestas de toros en casi todos los días de verano (y en otros fuera de él) o en Cádiz, o en el Puerto de Santa María, o en Jerez, a las que por la inmediación de estos pueblos concurren las gentes de los tres, como si se corriesen en el propio, conducidos de la extraordinaria afición que -aun los más pobres artesanostienen a semejantes espectáculos. Todos conocen los gravísimos perjuicios que de ello resulta al servicio de ambas Majestades y al Estado y aunque la mayor y más sana parte lo confiesa, - -y siento son pácos los que lo lloran-, porque or no duele el mal como es justo, o no sa conoce con claridad que, mientras lo haya, no podrá establecerse la industria». Se trasluce, en estas palabras de desánimo, el trabajo que le costará a la Sociedad el poder cuajar en un ambiente tan poco propicio.

BAEza, si bien restringida a una sola ciudad y a un corto número de individuos, tiene la gloria de haber sido la primera que pensó en imitar a la bascongada, extendiendo su acción a todo el reino de Jaén. Pero confiesa llanamente que (sufre una visible decadencia». Paradójicamente, ha sido víctima de las luces. La realización de otros proyectos ilustrados han acarreado muchas dificultades. La cría de ganado no pudo adelantar por la escasez de pastos (a causa de las muchas aldeas que por falta de defensa de esta ciudad se han eximido de su jurisdicción, y de 14.000 fanegas de tierra que tomaron las colonias de Sierra Morena para su establecimiento, causa verdadera, no sólo de la decadencia sino de la despoblación ${ }^{17}$. ¡Inesperada consecuencia de la colonización de D. Pablo de Olavide! A pesar de no disfrutar de una situación desahogada, la Sociedad puede pre-

17 En dos siglos, Baeza y su comarca perdieron más de 6.000 vecinos. 
sentar un balance de sus operaciones nada despreciable. En agricultura, además de mejorar la cosecha de granos y bonificar las especies, tha premiado la labor de «sacar suelo», llamada vulgarmente «cabotoño», que consiste en una cava de azada, profunda y costosa, pero que tiene la ventaja de aumentar notablemente, durante cinco años, la fiertilidad del terreno. Tiene proyectado sangrar el Guadalquivir por el lugar de la Herradura para regar las dilatadas campiñas de sus orillas. Introdujo los cultivos de cáñamo, lino y maíz que dieron pingües cosechas y propugnó la labranza con bueyes en vez de mulas. Consiguió que los artesanos adelantasen en sus respectivos oficios. Los curtidos se perfeccionaron y pueden aventajar a los mejores del reino, gozando de gran aceptación hasta la Mancha de Toledo. Cuando se fundó la Sociedad, no había en Baeza un solo telar de paños; ahora pasan de 13 los de paños y bayetas. Se tejen lienzos, mantelerías y cotonías tan buenas como las de Galicia, beneficiándose esta industria de la presencia en el mismo centro de la ciudad de una fuente excelente para los tintes. En fin, la Sociedad repartió premios en sus Escuelas Patrióticas de dibujo y desterró el inveterado y perjudicial abuso de no trabajar los lunes. Realizaciones, por cierto, modestas, pero concretas.

En sus tres años de existencia, el Cuerpo Patriótico de santiago fundó tres escuelas gratuitas (una de dibujo con una colección de papeles y yesos, una de enseñanza de primeras letras y otra de hilazas que proporciona géneros de buena calidad). Difundió en la provincia el uso del torno de hilar. Respaldado por el clero y el Ayuntamiento, formó el plan de una Junta de Caridad encaminada a extinguir la mendiguez y corrigió varios abusos. Los socios gallegos no descuidaron, por supuesto, la agricultura. Hicieron viveros, "almásigas» de varias especies de árboles con miras a una repoblación masiva de los montes. Fomentaron las artes, concediendo premios de emulación a los mejores artesanos. Hubieran deseado hacer más, pero las circunstancias no se lo permitieron.

«Sin embargo de ser corta la población y no haber en el partido sino labor y ganaderían, la Sociedad de CIUDAD RODRIgo procuró dar empleo en las hilazas a muchos pobres. Se creó una fábrica de bayetas con todos sus utensilios, llamando a maestros de Cubillana (Portugal) y de Béjar para la enseñanza técnica. Gracias al ingreso que se le aplicó de la vacante del obispado, se pudo instalar cómodamente la aludida fábrica en la Casa Hospicio. Pero, pese a los esfuerzos de los socios, decayó el establecimiento. También costeó el Cuerpo la instalación de dos fábricas de loza, blanca la una, la otra imitando la de Segovia. Habiendo publicado uno de sus individuos el método de fabricar el estuco, le alentó la Sociedad y en 1786, al- 
gunos alumnos del citado socio estaban trabajando en unos retablos de la catedral de Coria. Algo pues se hizo en el marco de actividades impuesto a aquellas entidades patrióticas por sus estatutos.

Segovia cuenta sus dificultades con ruda franqueza. Ha establecido una escuela de dibujo, pero nada próspera como era de esperar, porque el Corregidor no lleva a la práctica las providencias que sugiere la Sociedad. Tampoco van bien las siete escuelas de hilazas ( 4 en Segovia y 3 fuera) ni corresponderán jamás a los gastos y trabajos que acarreó tal implantación «mientras las mujeres y niñas vivan como lo hacen aquí, con toda libertad, y tengan en la puerta de los conventos segura la comida». Existe una escuela de costura con maestra y ayudanta bien dotadas y una importante fábrica de paños que, bajo el mando de la Sociedad, ha recobrado su prestigio. Queda todavia mucho que hacer: contrarrestar la despoblación forestal, limpiar las calles, fomentar la agricultura, reformar las escuelas de primeras letras y elaborar nuevas ordenanzas para los artesanos.

En vera, que fue la primera Sociedad Económica del reino de Granada, la decadencia fue producida por el temor de la responsabilidad del caudal adelantado por el Rey sobre los propios de la ciudad, con calidad de reintegro al cabo de seis años. De 1776 a 1779 , se quedó la Sociedad paralizada sin saber en qué materia invertir dicha canticlad, sin riesgo de quiebra o malversación. Por fin, lo empleó en una fábrica de esparto. La Sociedad fundó escuelas de primeros rudimentos y un estudio de gramática donde se enseña la política civil y cristiana. Ayudó al gremio de pescadores, anticipándole dinero. En 1784, la Comisión de Agricultura, en vista de la escasísima cosecha de la ciudad y de su jurisdicción, compró semillas que fió a 199 labradores a precio muy barato. Llovió mucho y los campesinos pudieron reintegrar al Pósito la mayor parte de sus atrasos. Pero la más importante creación fue la de la fábrica de esparto, planta que crece con abundancia en la provincia y cuya riqueza natural se desconocía y desperdiciaba. En ella, encontraron trabajo algunos jornaleros pobres. El Ayuntamiento cedió todo el esparto que produce la marina de Jaravia que antes no se beneficiaba sistemáticamente. Se vende el género a los extranjeros y a los pueblos vecinos de Cartagena, Aguilar y Almasarrón. Con los fondos que saca de esta manufactura, se mantiene la Sociedad. Desgraciadamente, unas órdenes gubernativas han alterado este equilibrio, ya muy precario de por sí.

Los responsables de CUENCA, en el informe circunstanciado, lleno de datos interesantes, que dirigen al Consejo, subrayan que la Sociedad es demasiado reciente (1783) para que se pueda hablar de decadencia. Pero 
no ha tenido el progreso anhelado en un principio. Costeó plantíos de moreras y siembra de frutos desconocidos en la comarca. Se estudió el regadío de la vega de Tordera. Se investigó sobre el cultivo y propagación de las atochas ${ }^{18}$ en la provincia y sobre las posibles minas de carbón. Se hizo un ensayo de creación de escuela de dibujo, trayendo un maestro de fuera, pero el intento fracasó. Actualmente la Sociedad "pone la mayor atención» en la creación de una escuela de primeras letras. Pero todas estas idiaas e iniciativas no prosperan, los proyectos no cuajan y el tesonero esfuerzo de un puñado de socios, surte finalmente escaso resultado.

Más al sur, la Sociedad de vélez málaga no parece tampoco muy boyante. Sólo tiene en su haber al cabo de tres años de existencia tna realización, útil por cierto, pero muy modesta: la creación de una escuela de niñas en que se han enseñado 41 de ellas y aspira, cuando tenga medios suficientes, a establecer otra escuela, de primeras letras ésta, «de que experimenta una carencia dolorosa la población». Sumida en estado de pobreza "no ha tenido decadencia, comentan los dirigentes, porque nunca ha tenido más incremento, ni' en la situación actual se puede esperar la tenga».

La Real Sociedad Caritativa-Económica de AlAEJos ha logrado implantar dos fábricas, una de velas de sebo de superior calidad y otra de esteras. Ha desterrado la mendiguez, recogiendo a los pordioseros en la casa de Misericordia. Con el producto de la colecta semanal que hacen los socios de puerta en puerta, mantiene una escuela gratuita de niñas a donde concurren 140 educandas. Pero, agrega, es necesario hacer más, porque «la instrucción es la felicidad». Ha procurado fomentar las artes, dentro de sus posibilidades mıy limitadas. En agricultura, su acción tropieza con los prejuicios y la rutina de los labradores que «aran y siembran como hace cien años»).

El Cuerpo Patriótico de medina de Rioseco anda todavía en pañales, pues se creó en 1785. Venciendo no pocas resistencias y trabas, los socios descubrieron y alumbraron aguas. Mas la obra que suscita su orgullo es la construceión de una vistosa calzada que arranca del suntuoso areo de la Plazuela de San Francisco hasta entrar en la ciudad. Tiene 500 pies de largo y viene rellenada con tongadas de piedras, guijos y arena leganosa. La obra, concluida ya, es transitable y quiere ser un testimonio, ante los ojos de los conciudadanos nada favorables, de la utilidad del nuevo Cuer- 
po: “Todo con el fin tle que los naturales reconozcan los efectos de las Sociedades).

Otras entidades, a veces de fundación antigua, han degenerado poco a poco sin remedio y yacen en una total postración.

«Es cierto, reconoce D. Julio Vigil de Quiñones, Director de la Sociedad de sIgüEnza erigida en 1776, que el Cuerpo ha llegado a tal inacción desde el 15 de rebrero de 1781 en que celebró su última junta, que no consta haber hecho otra, ni gestión alguna, hasta el 22 de abril último [1787] en que se congregó para oír dicha carta de V. A. '[se trata del recuerdo] y comisionar su respuesta, siendo seis años los que ha estado como muerta). En sus cinco primeros años de actividad, abrió dos escuelas de hilado y costura para niñas, distribuyendo premios y dotes y tomó varias disposiciones para fomentar la agricultura, artes y oficios, pero todo se quedó parado después.

En Toledo, más bien que decadencia, es falta de desarrollo, lo que aflige a la Sociedad. Desde su establecimiento, afirman los redactores del informe, no ha tenido ni tanto número de socios ni estado más floreciente que el de la actualidad, pero "carece aún de mucha parte de aquella representación, decoro y facultades a que podía aspirars. Esta frase ambigua disimula una ausencia total de realizaciones y el hecho es que Toledo arrastra y arrastrará siempre una vida de suma languidez sin esperanza de mejoria.

Tunela, aunque muy aletargada, subsiste (merced a un prodigioso efecto de la ejemplar firmeza y constancia de los pocos individuos que la componen». Tiene que aguantar los desaires del Ayuntamiento, que por todos los medios a su alcance, intenta desacreditar a los Amigos del País. “Los proyectos más interesantes para las riquezas de este pueblo, relatan amargamente los firmantes, que son sin duda el aprovechamiento y manufactura de sus lanas y el de la extracción de sus vinos a la Rusia... los ha hecho inútiles la frialdad con que generalmente se reciben las especies de la Sociedad). El vino tinto que se despacha en Tudela a tres reales y medio, se vendería puesto en Petersburgo, con deducción de todos costes y derechos, a once reales y el blanco en vez de cinco reales, a 33 , siendo pues el beneficio considerable. Pero nadie quiere suscribir las 160 acciones de a cien pesos cada una y la poca honradez del negociante que quiso enviar a Rusia en pellejos un vino de no muy buena calidad, provocó la desconfianza de los compradores y hundió el mercado. Por su parte, los ganaderos podrían, con tal de seguir los consejos de la Sociedad, embolsar anualmente 55.028 pesos. Pero no le hacen caso. Esta actitud despectiva, de verdadero 
rechazo, ha originado la retirada de muchos socios y la ruina de la Sociedad.

En lucena, la situación es desesperada. Establecida en 1782, la Sociedad ha tropezado desde entonces con la inquina del duque de Medinaceli que le niega obstinadamente su cooperación y desbarata todos sus planes. Además, la ciudad ha sufrido muchas calamidades y una epidemia general. El pueblo se encuentra en la mayor miseria, sin asistencia de médicos, falto de medicinas y alimentos, pereciendo en esta infelicidad y esperando su único socorro de la caridad de sus conciudadanos.

El Cuerpo Patriótico de la gomera padece también de circunstancias adversas y choca con la oposición del marqués de la Bélgida y del conde de La Gomera en varias de sus pretensiones. La isla es estéril, una violenta epidemia ha castigado a la población, ya disminuida por la traslación de varias familias para la Luisiana, la leva de reclutas para la Habana y Caracas. La vida se hace difícil por la carestía general. Tiene la isla que cargar con derechos de aduanas mayores que en las demás islas del archipiélago y está peor tratada que su vecina Hierro. No tienen sus hijos ninguna salida posible. Muchos vagos $\mathrm{y}$ viciosos infestan su suelo, tolerados por las autoridades. El panorama es francamente desolador.

Requena, ciudad rodrigo, la bañeza, en la que los telares de cintas y demás proyectos útiles están parados, YEPES también, entran en esta retaguardia de cuerpos moribundos, agónicos. Con tristeza, el Director de la Sociedad de Yepes, D. Josef Hernando de Soto, denuncia «la decadencia, o por mejor decir, la infundación de la Sociedad de la villa de Yepes, que por falta de base, nunca pudo prosperar» y yace en un (estado de inanimación», concluyendo con estas palabras sentenciosas: "Primero es ser que obrar).

Un caso muy particular ofrece la Sociedad de SANTANDER que puede incluirse también entre las que, después de fundadas, no prosperaron. La razón, muy sencilla, la expone el conde de Villafuertes: “Algunos celosos Patricios montañeses solicitaron hace años la aprobación del Consejo y del Rey para una Academia de Ciencias y Artes útiles, a imitación de LA BAScongada. El Consejo y el Soberano aprobaron esta pretensión, así como los estatutos formados. Pero la Secretaría de Estado se negó a concederle el título de Cantábrica al que aspiraba, imponiéndole la denominación de Sociedad de Santander. «Es tal, prosigue el Conde, el entusiasmo de los Montañeses por sus antiguas glorias que, en medio de haber suserito algunos centenares de personas de lo más ilustre para el nuevo establecimiento de 
la Sociedad, cuando se trataba de darle el título de Cantábrica, se negaron casi todos a ser socios o contribuyentes, excepto los de esta ciudad, después que supieron el título que se estimó en la Real aprobación». Como no cejó la Secretaría de Estado, se quedaron en sus trece los Cantábricos y no celebró juntas la Sociedad. Esta prueba de fuerza había de durar largos años.

Exceptuando pues a unas cuantas Sociedades de desbordante y admirable vitalidad, conseientes de su incansable labor en pro de la nación, que se disgustaron al recibir la circular del Gobierno por juzgarla injusta, ofensiva e inapropiada, es patente que muchas otras se encontraban efectivamente en un estado deficiente, cuando no agónico, que motivaba plenamente la intervención del Consejo.

\section{CAUSAS DE DECADENCIA EN LAS SOCIEDADES ECONOMICAS}

\section{A. - SITUACION GENERAL EN ESPAÑA}

Antes de discutir su presunta decadencia, MADrid recuerda al Consejo el pésimo estado de abatimiento y marasmo en que está sumido el pais y que tiene nefastas repexcusiones en todas las instituciones: "Una nación a quien por el discurso de los siglos han 'puesto en decadencia las guerras y conquistas, la debilidad de los reynados y el deseuido e ignorancia de las ciencias útiles y exactas, no puede en un corto periodo de tiempo repararse ni vencer los obstáculos que se oponen a su felizidad; es preciso ir preparando insensiblemente esta favorable revolución... que, cuando el erario está exhausto sin que puedan los más fecundos arbitrios extinguir la deuda nacional, cuando ocupan la primera atención otros objetos, los ramos subalternos deben caminar lánguidamente a proporción del impulso débil e interrumpido que los mueve ${ }^{19}$. España es un cuerpo pesado, pasivo y el Estado una máquina anticuada y medio paralizada.

19 Arch S. E. M., leg. 79/10. Sacaba el censor su argumentación del informe de la Clase de Industria firmado en 21 de diciembre de 1786 por los socios D. José Almarza, 
Las Sociedades económicas, órganos creados como paliativos a tan lastimosa situación, no pueden por sí solas hacer mudar enteramente el semblante de la nación y sobre todo en tan reducido plazo. Su eficacia choca con numerosas trabas de toda índole y ellas mismas ven entibiarse el celo de sus individuos por la imposibilidad en que están de remover obstáculos.

La Clase de Industria de la matritense que establece una comparación con otros cuerpos de más antigua fundación que las Económicas, juzga que aquéllos han contribuido en poco o nada al hien de la patria y encuentra muy injustas las críticas del Consejo, pues «la lentitud no es peculiar de las Sociedades, sino de todos los cuerpos cuyos vicios son inherentes a su constitución y si unos pretenden lo contrario, es un delirio filosófico» ${ }^{20}$. El delegado de Artes y Oficios considera «como una especie de prodigio la permanencia por un espacio de once años, de un establecimiento como las Sociedades, sin fondos, sin dotación alguna, sin más auxilios o recursos que el patriotismo» ${ }^{21}$. Otro socio matritense exclama: "No es poco milagro que un establecimiento de esta naturaleza, totalmente precario, sin dotación alguna, con unos principios tan estériles, rodeado de tantos estorbos, preocupaciones y dificultades y sin más proporción auxiliar que el patriotismo, haya podido no sólo permanecer con tanta constancia por el espacio de once años, sino también florecer y fomentarse hasta el estado a que ha llegado». Alaba «la devoción que lo produjo y el fervor que lo conservó» ${ }^{22}$. A su vez advierte LA BASCONGADA: "Es una suerte que se hayan constituido semejantes Cuerpos, y es asombroso que sigan existiendo y actuando a pesar de los óbices con que chocan a menudo».

D. Antonio Blanco y D.Joaquín Juan de Flores y que le fue remitido en 20 de enero siguiente. (Véase, S. E. M., leg. 73/62). Al compendiar las reflexiones de la Clase de Industria, el Censor las expurga y edulcora, quitando por ejemplo aquellas que constituian vehementes críticas contra el afán guerrero de la Nación y los gastos militares: «...Quando los ramos que por una política sanguinaria se estiman más interesantes al Estado ocupan la primera atención; quando el fanatismo militar o el escrupuloso y delicado honor de un pueblo acostumbrado a representar un papel brillante en el teatro de la Historia, le comprometen en una empresa gloriosa al paso que funesta; en vano se buscan en los objetos subalternos sino unos progresos lánguidos y lentos, según el impulso que los mueve, débil e interrumpido»,

20 Ibidem.

21 lbidem, leg. 82/48, D. Manuel Sixto Espinosa, 21-II-1787.

22 S. E. M., Ieg. 82/26, parecer de D. Juan Bautista de San Martín, Madrid, 9 de agosto de 1786. 
No obstante, la precariedad de su instituto y de su falta de estructuras, el Estado les ha confiado una empresa desmesurada, verdaderamente colosal. Las Sociedades tienen que enfrentarse con una gran variedad y multitud de asuntos enredados y vidriosos. Cada clase, cada ramo pediría separadamente erigirse en Sociedad, observa con razón cuenca. Frente a la inmensidad de problemas y lacras descubiertas, frente a tantos ambiciosos planes de mejoras y reformas, cuanto realiza en su órbita cualquier Cuerpo, con el solo recurso de sus fuerzas y abnegación, parece pequeño y desdeñable. Frenados en su arranque por la propia impotencia del gobierno, decaen los ánimos de los socios y el Estado que, por otra parte, esperaba verdaderos milagros de aquellos cuerpos patrióticos abandonados a sus solas fuerzas, se siente defraudado.

La decadencia de la nación es, pues, factor de decadencia también para las Sociedades. Además, el momento en que lanza el Consejo su inquietante circular, no puede ser más inoportuno. En efecto, la situación sanitaria de España es tan deplorable que da grima. "Innumerables enfermedades aquejan el país», informa la Sociedad de cuenca y «se comen todas las limosnas disponibles»). España conoce horas difíciles en un ambiente de tristeza y de desolación. En realidad, la salud pública empezó a deteriorase en marzo de 1783 , mes en que hizo su aparición en Cataluña una epidemia de calenturas de mala indole y que pronto invadieron todo el Principado. El contagio tuvo principio en Lérida, donde causó grandes y rápidos estragos, sobre todo en las personas más robustas de 20 a 50 años.

El año 1784 se caracterizó por malísimas cosechas, copiosas lluvias y repetidas crecidas e inundaciones, trastorno climático en el que vieron muchos médicos de la época la causa de las desgracias que se abatieron sobre la península. Aquel mismo año, Sevilla y Sanlúcar de Barrameda sufrieron los primeros ataques de tercianas que se extendieron a toda Andalucía. La provincia de Aragón se vio contagiada en la primavera de 1785. Unas fiebres malignas se apoderaron de muchos pueblos y persistieron todo el verano, otoño e invierno siguientes, causando muchas muertes, hasta el punto de que, cuando viajó D. Felipe O'Neille a Zaragoza para servir la capitanía general, apenas si había en los pueblos de su tránsito gente sana para hacer la sementera. En Barbastro, la mortandad fue tal que nadie atendía las labores del campo, y todo quedaba abandonado. A finales de 1785, cundió la epidemia hasta Cartagena. El día 3 de enero de 1786 , pasaba ya de 1.200 el número de enfermos. Alcanzaría la cifra de 12.563 a lo largo del año. En el solo lugar de Navalcarnero, se contaron más de 2.000 contagios; en San Roque (Toledo), se multiplicaron desde 1785 hasta lle- 
gar a 3.042. En el Viso (Mancha), además de los síntomas comunes de las tercianas malignas, se observan en los pacientes manchas moradas y negras, carbunclos, bubones y llagas cancerosas. En todas partes, reinan pues en aquel año aciago de 1786 las temibles calenturas, ya malignas y pútridas, ya nerviosas y remitentes, muchas veces acompañadas de convulsiones, apoplejías, gangrenas y otros accidentes peligrosísimos. Se cuentan por decenas de millares Ios enfermos. Menos lo más apartado de Galicia, que escapa esta vez, todo el territorio de la península está infestado. Buena prueba de ello nos la da la lista de las diócesis que recibieron del Estado arrobas de selecta quina para aliviar los padecimientos de los enfermos y salvar vidas: Toledo - Sevilla - Granada - Valencia - Zaragoza - Cartagena - Salamanca - Zamora - Badajoz - Lérida - Gerona - Sigüenza - Cuenca - Jaén - Palnncia - Orense - Teruel - Huesca y Segovia. Todas las autoridades civiles y religiosas están movilizadas y participan en la campaña de socorro (obispos, corregidores, individuos de ambos cabildos, clero, ciudadanos, colectores de expolios, facultativos, personal hospitalario, instituciones benéficas, juntas de caridad). Se distribuyen víveres y quina, se recogen limosnas públicas; grandes cantidades de dinero se invierten en auxilio de la pobre gente. El daño es a escala nacional y acapara la atención de todos. A pesar de que pocas Sociedades aluden a esta situación catastrófica, es evidente que ésta no pudo menos de influir, ya en la concurrencia de los socios, ya en el agotamiento de sus escasos caudales, y tal vez se pueda ver en esos tristes sucesos que duraron tan largos años otro factor circunstancial de decadencia para las Sociedades.

\section{B. - LOS SIETE FACTORES DE DECADENCIA}

Después de trazar el marco general en que evolucionan las Sociedades, condenadas a una muy relativa eficacia por el sin fin de problemas y cuestiones que tienen que solventar, los responsables examinan y discuten las posibles causas de decadencia.

\section{1) Excesiva proliferación de las Sociedades}

Se puede buscar el origen de la decadencia de los Cuerpos Económicos en el número por demás elevado de las que se establecieron "por un celo indiscreto" y muchos en lugares de vecindario corto. "Así que, comenta SANTIAgo, faltos de los conocimientos necesarios e imposibilitados casi de adquirirlos, y siendo preciso que sus miras y sus ideas, por limitarse a un

corto pais, sean poco generales, están necesariamente expuestos a muchos 
errores políticos y a molestar al Gobierno con representaciones y recursos poco juiciosos y a veces contradictorios, los cuales, ya que no producen otro mal efecto, desacreditan siempre a todas las Sociedades indistintamente».

Granada expresa el mismo parecer: "No hay que multiplicar las Sociedades. Lejos de poder subsistir muchas de las de los pueblos subalternos, ha sido, sin duda, su erección, el principal origen de la presente cu mún tibieza y causa presuntiva de una futura general decadencia». Estas observaciones de buen sentido se ven confirmadas por los informes procedentes de varias Sociedades pequeñas o mediocres, aunque suelen éstas poner el énfasis sobre la falta de medios económicos antes que sobre la escasez de recursos humanos y de luces. Así se queja yePEs de ser «un cuerpo sin alma» - hemos visto que se califica con la palabra (infundación»porque no ha tenido los fondos indispensables para su establecimiento. La Sociedad de sigüenza recuerda que se ha implantado en una ciudad mísera, de sólo 8.000 habitantes, número muy insuficiente para que prospere: «Acaso, dice, no habrá en todo el reino una ciudad más pobre, más necesitada de la Real atención». VÉLEZ málaGa confiesa que «se concibió en una poquedad de nervios y cimientos para poder subsistir». Vera reconoce que sin las gracias concedidas por el Rey, es indudable que hubiera sido dificilísimo fundar la Sociedad por el corto número de vecinos que componen la población.

LA ARAgonesa apunta el peligro que entraña la multiplicación de las Sociedades y para ser más convincente, trae a colación el ejemplo de Francia: «No convienen muchas Sociedades dentro de una misma provincia, pues por haberse multiplicado en Francia las de Agricultura, se ve su poca prosperidad. Causan molestias todos los días al Rey y a sus ministros y por falta de uniformidad en los principios y de la necesaria instrucción, son enfadosas y piden cosas impertinentes y acaso contradictorias». España que tiene ya 45 Sociedades establecidas ${ }^{23}$ y muchas en poblaciones de poca monta, adolece del mismo mal.

LA ARAgonesa propone como modelos a imitar a la Regia Sociedad de Londres, la de Dublín, o incluso LA BASCONGADA, que «sin embargo de abrazar tres provincias, es sólo una la Sociedad».

Acaso sea JACA el caso más significativo de esas fundaciones artificiales,

23 Esta cifra no corresponde a la del expediente, que menciona a $4: 2$ de ellas. Las otras tres son posiblemente Valencia, Mallorca y Tárrega (véase nota 6). 
irreflexivas, e inoperantes, cuando no contraproducentes. En su informe, zaragoza expone al Consejo las circunstancias de esa creación: "La Sociedad Aragonesa cubre trece corregimientos, en todos los cuales tiene socios correspondientes. Pero, por fines particulares de dos o tres sujetos de Jaca, acudieron a V. A., callando los antecedentes, y obtuvieron prermiso para erigir en aquella ciudad una Sociedad independiente de LA ARAgonesa. Esta representó a V. A. que no podía ser permanente semejante Sociedad en Jaca. Pequeño Cuerpo, con cortas fuerzas, opuesto a las máximas del de que procedía, sin libros ni fondos, iba mendigando las noticias que necesitaba. Lejos de adquirir luces, sus socios se ofuscaban más entre las tinieblas, mayormente cuando era delito poner en ejecución las instrucciones que había recibido de la capital su Sociedad matriz. Así, en corto tiempo, se vio enfermo y decadente el pequeño Cuerpo, sin fuerzas para poder convalecer, dispersos sus miembros y del todo desengañados».

Ejemplo muy aleccionador y que, unido a los anteriores, demuestra de modo palmario que las Sociedades fundadas en mezquinas poblaciones no lograron prosperar y que fue por parte del Consejo un fallo político, una falta de realismo, haber permitido su implantación sin las garantías básicas imprescindibles. Su poco desarrollo o su ningún progreso fue lo que dio pie al Consejo, responsable de tan anómala situación, para redactar su circular.

\section{2) ¿Espíritu de partido? ¿Desunión?}

Una hipótesis formulada por la Circular del Consejo para explicar Ia decadencia de las Sociedades es la existencia de partidos disolventes, de rivalidades y discrepancias en el seno de aquellas corporaciones.

Es cierto que algunas respuestas aluden a esta posible causa. VÉLEz MÁLAGA reconoce, además de alguna tibieza entre los socios, «la repugnancia y oposición de algunos partidos que tuvo al concebirse». En sigüenza, la Sociedad «se ve casi perdida por su pobreza y desunión» y abocada a la catástrofe.

Por lo visto, no fueron muy graves estas desavenencias y no pasaron de fricciones o heridas de amor propio. Muy contadas son las Sociedades que las mientan. Lo hacen de paso, sin darles importancia, como si se tratara, por mera cortesía, de no infligir un mentís al Gobierno. Vera admite: "Hubo algunas desavenencias, pero en los periodos de desaliento. Porque el éxito reúne a los Socios». Con ingenuidad, JEREz de LA FroNTERA ve la desunión, no como un hecho real, sino como una amenaza, un peligro que se cierne sobre el Cuerpo. «Este peligro está, dice, en la 
mayor frecuencia de juntas, siendo más perjudiciales aun las juntas de elección». Entonces, se pregunta uno: ¿Por qué crear una Sociedad si el solo hecho de que celebre juntas entraña un riesgo de desagregación?

Tampoco está muy clara la postura de LA ARAGonesa, que incurre en una contradicción. Después de afirmar categóricamente que «no han tenido ni partidos ni diferencias entre sí, antes bien han mantenido la mayor unión »..., relata con gran lujo de pormenores la desobediencia y escisión de la sección de Jaca. En cuanto a la matritense, no rechaza de plano la posibilidad de algunos gérmenes de discordia, concretamente en la Clase de Artes y Oficios que "ha sido siempre la más asidua de individuos y lo sería mucho más si no se hubiera introducido en ella cierto espíritu de partido». Pero, por otra parte, afirma: “La única división es división o diversidad de opinión, muy útil en materias dudosas para una investigación de la verdad». La Clase de Industria niega que haya habido discordancias entre sus individuos: «El celo ha sofocado siempre el ligero resentimiento que causa la diversidad de dictámenes) ${ }^{24}$. El señor Ascargorta que aparece como un teórico de LA MATRITENSE, admite en su dictamen ciertas pequeñas divergencias existentes en el Cuerpo, pero recalca el hecho de que son normales y de poca monta: "Tal vez, concede, se hayan notado... algunos partidos destructivos de la buena harmonía que debe reinar. Pero este mal, lo juzgo inevitable a todos. Lo empieza la diversidad de opinión, lo acalora la dificultad de convencerse y la decisión, que necesariamente desagrada a algunos, lo perpetúa. La docilidad debiera caracterizarnos a todos. Pero la reunión de un número crecido de entendimientos dóciles que no degeneren en serviles, me parecería un fenómeno s ${ }^{25}$.

Esta opinión matizada y moderada es la que adoptará finalmente la Sociedad en su respuesta oficial a la Circular: “En un Cuerpo como éste en que reina este espíritu de patriotismo, de celo, de amor al trabajo y de deseo de la felicidad pública en desempeño de su instituto, no puede haber partidos que destruyan la armonia y embaracen el curso de las buenas ideas y adelantamientos. No se conocen otros partidos que el de la razón; en caso de duda, se pasa a la votaciónı.

Otras Sociedades recusan totalmente la incriminación del Consejo: SANTIAGo proclama: “No hay partidos, sino armonía en el seno de la Socie-

24 Arch. S. E. M., leg. 79/10.

25 Ibidem, leg. 73/4, dictamen del Sr. Ascargorta, Madrid, 31 de agosto de 17--, 13 folios. 
dad», y segovia: “No se ha observado la menor desavenencia, antes bien, la mayor armonía». En oviedo, “no se ha notado ninguna parcialidad». CIUDAD RODRIGo asegura que existe la mayor concordia entre sus individuos y que (se evita toda parcialidad cuando concurren». Cuenca declara a su vez: “No hay aquí partidos ni altercaciones públicas que disturben o retraigan los ánimos». Sevilla afirma de modo tajante: « $\mathrm{Ni}$ disensiones, ni partidos).

Vergara da en fin la nota justa: “En toda junta de muchos hombres, es inevitable la diversidad de opiniones y las controversias avivan el celo de los socios» y sugiere el ejemplo del Parlamento británico en el que hay partidos y controversias, "pero siempre están unidos los votos de todos para concurrir en la conservación del Cuerpos.

Se ve pues que este punto de la supuesta desunión interna de los Cuerpos Patrióticos, sobre el que insiste pesadamente el Consejo, no originó debate. Las Sociedades rechazaron la insinuación o le restaron toda importancia. Bien claro está también que, para asegurar su supervivencia, mejor valía no caer en la trampa armada por el Consejo y negar rotundamente toda disidencia en sus filas. Así lo entendieron.

\section{3) Clima poco propicio}

Las causas verdaderas de decadencia, hay que buscarlas primero, opinan los dirigentes de las Sociedades, en el medio ambiente. Si no prosperan ciertas Sociedades a pesar de los esfuerzos de sus individuos, la culpa es de la indiferencia e ignorancia del público, del interés y egoísmo de distintos grupos, de sus prejuicios y malicia.

La implantación de Sociedades no despierta interés en el vulgo que queda indiferente $y$, por falta de información, no entiende su papel. Recordemos que la matritense se quejaba al ver tantos ejemplos de virtud patriótica (sepultados en oscuro silencio» y condenados a recoger, por único galardón, críticas y murmuraciones. Y así, «el público ignora casi todos los trabajos de la Sociedad Económica Matritense, se queja el señor Ascargorta, porque el Cuerpo no tiene medios necesarios para imprimir sus actas ni en ellas puede parecer la multitud de informes hechos a S. M. y a sus tribunales» ${ }^{26}$. El hombre suele despreciar lo que ignora y LA MATRI-

26 Ibidem, idem. 
TENSE, no sin amargura no extraña que el público le deniegue toda utilidad porque desconoce el alcance y la amplitud del papel que desempeña realmente ${ }^{27}$.

Cuenca da una forma aun más contundente a este argumento: «Alegan muchos que no es útil semejante instituto, subrayan el ningún provecho o bien temporal que de ello puede resultarles... Para que no medre... es muy bastante la interior opinión que forma cada uno y en que solo Dios manda».

Todas las iniciativas de las Sociedades chocan con la incomprensión, la animadversión, los prejuicios y la rutina. Ofrecen premios, nadie concurre, observan con desaliento los conquenses: “No sabemos como desvanecer las preocupaciones, mudar los genios... La preocupación, este monstruo que aun a los mismos soberanos suele resistirse, no oye razones ni convencimientos, no cede a rigor ni a blandura. La interna libertad de pensar no reconoce humano señorío». Y para ilustrar la esquiva resistencia del pueblo a todas las novedades, añade: "Los Socios de agricultura hacen a su costa plantíos de moreras y siembras de otros frutos que no se conocían. Persuaden con razones y con experimentos que pueden ser útiles. Nadie los imita. Unos porque ven que no nacen como si fueran hongos, a vuelta de cabeza, otros porque el sacarlos de su trigo y de su cebada, es obra de Romanos). BAEza que tiene corto número de socios, intenta aumentar sus listas de contribuyentes, atrayendo a gente de los pueblos vecinos. Pero éstos, envidiosos e inconscientes del beneficio que les podría resultar de su incorporación, no se mueven y denigran a la Sociedad.

Esta antipatía hacia las Sociedades no se limita a una oposición sorda y difusa. Se hace activa y cobra a veces visos de violencia o de coacción física. Cuenta tudela: "Las instigaciones contra la Sociedad llegaron al término de intimidar a varios socios, insinuándoles que por serlo, se les perseguiría en sus intereses, como en efecto lo empezaron a experimentar, y por ello, se retiraron algunos de la Sociedad, porque a tan fuertes conminaciones sólo puede resistirlas una absoluta independencia o el heroísmo». Lo mismo pasó en REQUENA. Los socios plantaron grandes extensiones de moreras y olivos. Pero, de noche, hubo gente que cortó gran número de plantones, causando daños de consideración. La justicia no tomó providencia. Tuvo la Sociedad que entenderse con el Ayuntamiento para nombrar

27 Véase pág. 100. 
celadores y guardas, pagados al alimón por los propietarios. Sólo así escarmentaron los malhechores.

El recurso a la violencia es, sin embargo, excepcional y esporádico. Pero hay otras armas infinitamente más peligrosas, por insidiosas y ocultas: la murmuración, la calumnia, la mofa y la sorda inquina. "Hay maledicientes, nota oviedo, que ridiculizan las Sociedades y a los que en ellas se ocupan y todas sus operaciones». Por desgracia, no se trata de un hecho local, es una plaga a escala nacional. En valladolid, «se palpa el despreciativo concepto en que son tenidos los socios, viendo con el mayor dolor que estos Cuerpos son el objeto de la murmuración y del atraso en las carreras». Apunta SANTIAGo que hay cierta preocupación muy general contra las Sociedades: «Se ridiculiza el título de socio y se hace burla a los que asisten a sus juntas y desempeñan con actividad sus encargos, lo que retrae a un gran número y es causa de que, residiendo regularmente en esta ciudad más de cien socios, haya muchas juntas en que no llegan a ser diez los vocales». Y en LEón, «luego que vio el pueblo, bien hallado con su infelicidad y prácticas de sus mayores, el establecimiento de estos Cuerpos, levantó el grito contra ellos hasta ridiculizar a los que se aplicaban a tan saludable objeto». La palabra "ridiculizar» vuelve insistentemente en boca de los informantes y revela que los socios tienen que aguantar invectivas, cuchufletas y mortificaciones.

¿Cómo los escarnecen los malévolos? Con un mal retruécano, como lo confiesa ingenuamente YEPES que dice «haber tenido que sufrir los dicterios de los maledicientes que llaman a la Sociedad (Suciedad» y a los socios "Sucios», sofocando de esta suerte unos proyectos que merecen las atenciones de nuestro Soberano Carlos III el Benéfico y de sus altos ministros». Segovia, por su parte, señala el peligro de comisionar a individuos poco preparados que no hayan cursado la enseñanza de unas Cátedras de economía política y rural, porque «si fracasa uno de sus experimentos, se exponen a la mofa, burla e irrisión de los demás» y sale desacreditada toda la Corporación.

Esta actitud denigrativa del pueblo ignorante y aferrado a sus prejuicios no es lo más grave. La misma falta de interés y comprensión se encuentra a veces (existen desde luego numerosas y muy honrosas excepciones), en aquellos mismos que tendrían por sus cargos que proteger a las Sociedades. Muy escasa colaboración reciben los Amigos del País por parte 
de los representantes de la autoridad civil y religiosa ${ }^{28}$. "Hasta ahora, relata segovia, los justicias demostraron poco interés. Se les tiene mandado ayudarlas, pero en vez de: auxiliarlas [a las Sociedades], se mofan y ríen de ellas... y éstas no pueden prosperar... Hemos visto con dolor que los tales jueces son una especie de bajáes... que en aquellos asuntos que les competen, proceden según su antojo, atropellando por la justicia y la razón. ¿Cómo han de prosperar las artes y agricultura en un sistema de esta naturaleza? ni ¿cómo han de hacer progresos las Sociedades, viéndose a menudo ridiculizadas de los mismos justicias? En cuanto a los magistrados que debieran ser los oradores de estas comunidades, son con su propia conducta sus mayores enemigos y destruidores. Cuando alistados en estos Cuerpos, pudieran contribuir a la perfección de las intenciones reales y usando sus bellos talentos, enmendar los que creyeren errores de sus consocios, huyen con fastidioso rostro de nombrarse individuos, se deleitan en ridiculizar las justas y sencillas fatigas de la comunidad, y sembrando la semilla de la discordia en el insensato pueblo, que les cree oráculos, entibian el más enardecido espíritu y aun extienden su odio a los demás...) VALladolid acusa: «Los jefes de las ciudades donde se hallan establecidos estos Cuerpos, se desdeñan de acordar con los Directores, graduando indecorosa esta racional conferencia. Todo es desprecio, todo es abatimiento hacia la Sociedad y sus individuos y aquél se cree más hombre de juicio y circunspección que inventa más chismezuelos y esfuerza su oratoria contra estos establecimientos»). En tudela, la Sociedad tropieza con la enemiga de los canónigos y de los regidores. Coligados, se oponen a la creación de un hospicio del cual está muy necesitada la ciudad, como "proyecto criminal de una ambiciosa dominación contra los derechos y regalías de ambos cabildos), concepto que (concitó muchos émulos a la Sociedad y originó su decadencia». La fuerte impugnación que ha sufrido la Sociedad, explican los tudelanos, procede sin duda de la «baja y falsa idea que ha formado de ella la malignidad de sus adversarios que la presentan como un Cuerpo animado de ciertos espíritus ambiciosos que, bajo el especioso pretexto del bien común, sólo aspiran a establecer en el pueblo una autoridad imperiosa

28 Sobre este punto hay que evitar desde luego toda generalización. Muchas de las Sociedades incriminadas en la circular se quejan de la poca o ninguna ayuda que reciben del Gobierno y de las autoridades. Proporcionan datos y ejemplos concretos absolutamente fehacientes e inequivocos. Pero una gran copia de documentos opuestos podría revelar el papel preponderante que tuvieron muchos prelados, sacerdotes, nobles, justicias, etc... en el fomento y funcionamiento de aquellas corporaciones. En el presente estudio, nos limitamos a exponer los pareceres de las Sociedades, sin abrir debate. 
que, si no se resiste, llegará a ser despótica en el predominio de sus ideas. Protegida del Gobierno, será siempre servil con él, pero perniciosa a la franqueza y libertad de los pueblos a quienes deprimen». Con todas estas argucias y calumnias, las malas lenguas privaron a la Sociedad del afecto popular. En ZARAgozA, se han conferido gracias de regidores perpetuos de la ciudad a sujetos opuestos a la Sociedad, lo que provocó un movimiento de flojedad y desmayo en muchos socios. “Además del mal ejemplo, aquellos enemigos tratan de disculparse desacreditando los conatos y loables fatigas del Cuerpo». En Lugo, los alcaldes crean «algunos estorbos dimanados de preocupaciones vulgares, aun en muchos que, por sus empleos, deberían cooperar al bien común». Eso no constituye, por desgracia, un caso único. Establecida en 1785, la Sociedad de MEDINA DE RIOsEco experimentó desde las primeras sesiones la mayor animosidad y no esperada tibieza de parte del Ayuntamiento, desentendiéndose los capitulares de ser individuos de la Sociedad). La ARAgonesa denuncia el mismo poderoso factor de decadencia. Halla grandes obstáculos en los gobernadores de los pueblos y otras personalidades pertenecientes a la clase rectora, que acogen las mismas nociones perniciosas del vulgo. Influyen estas actitudes en el atraso que se nota en algunas Sociedades o delegaciones de las mismas y, en todas, tienen por consecuencia la disminución del número de contribuyentes y por lo tanto de sus fondos. En requena, el Corregidor, D. Antonio Josef de Castro, apenas instalado en su cargo, "empezó a mirar las materias y asuntos del Cuerpo como cosas de ningún mérito. Se le nombró socio honorario, le visitó el Director; él, ni siquiera devolvió la visita, ni asistió a una junta». Vélez málaga espera del Consejo de Castilla que tenga a bien «encargar por oficio al Corregidor que sea la protección y asistencia a la Sociedad y a sus intentos y operaciones útiles», exigiendo de él que presente en la Real Cámara una certificación de la Sociedad en la que ésta haga constar los servicios que le prestó. Piensa asi que, teniendo los jueces en los pueblos el principal influjo y estímulo, se imitará su ejemplo y se alistarán más adeptos.

Es frecuente en los socios, hasta en los de la matritense, la queja de que, si están expuestos a tanta crítica, es porque el Eistado les niega su apoyo y consideración. Y sin embargo, tenemos la prueba de que, en las esferas más altas del Gobierno, existe la voluntad de animarlos. En 1780 , Floridablanca encarga al Virrey de Navarra, D. Manuel Azlor, que recomiende la Sociedad tudelana a las Cortes de Navarra, invitando a los caballeros del pais a que se incorporen. Asi lo ejecuta, varias veees, el Virrey. Pero las Coxtes se niegan a dar este paso. En 1784, Floridablanca reitera su reeomendación a todas las autoridades del pais. Pero aninguno de los 
oidores, canónigos y prebendados ni caballero ninguno se incorporó». Este es un caso de desobediencia caracterizada. Ocurre también que no se acatan las decisiones del Gobierno por falta de un representante local del poder central, debidamente autorizado y competente. SIgüenza señala que «carece de un magistrado secular, corregidor sexenal, que pudiese promover y hacer observar las leyes y órdenes de S. M., mejor que lo pueden hacker unos alcaldes anuales que, aunque de muy buenas prendas y deseos, suelen ignorar algunos el leer y escribir, verificándose en el uno actual la falta de este preciso requisito que acaso no tendrá ejemplar igual en tales tiempos y circunstancias». "Para evitar el vilipendio y ultrajes de personas vulgares que hacen capa o impiden la recolección de mendigos», oviedo se ve en la obligación de pedir el nombramiento de un Juez protector a quien la Sociedad pueda recurrir.

En cuanto al clero, tampoco presta siempre la ayuda que era de esperar. VAlladolid lo vitupera con estas duras palabras: "Los obispos, cabildos y prelados de las religiones que... debieran celebrar y distinguir la concurrencia de sus súbditos a estos Cuerpos, su aplicación al beneficio público y tan honesta ocupación, son los primeros que los abaten... y graduándoles con una mala moral, distraídos de su instituto eclesiástico, los posponen en sus gracias, les niegan aquellos ascensos y preeminencias que, por el turno regular, les eran debidas, atropellando en desempeño de su odio los más claros estatutos de sus religiones, las inconcusas costumbres monacales, la suficiencia de las oposiciones y el mérito adquirido en el servicio personal de las iglesias). Srgovia deplora también esta defección del clero que se muestra hostil en vez de secomo lo ha previsto el Gobierno, agente propagador de las luces y clavija maestra de las Sociedades. En efecto, se sabe que, según los planes de Campomanes, debían los curas enseñar a sus feligreses, no sólo la moral cristiana, sino la moral social y cómo mejorar el estado de la República por el trabajo. Pero, exclama Segovia ¿cómo pueden hacerlo si no conocen esta materia y creen que no les incumbe enseñarla e incluso que las Sociedades son perjudiciales? "Los Párrocos, prosigue, deben contribuir al bien general de la nación, no sólo por ser miembros del Cuerpo místico de la República, sino también porque se hallan mantenidos a costa del sudor ajeno, para poder atender con desembarazo a la felicidad espiritual y temporal de sus feligreses). El obispo de Segovia, D. Alonso Marcos de Llanes, exhorta a sus párrocos de la tliócesis para que colaboren en los planes de la Sociedad. Pero sólo contestan algunos de Sepúlveda y el cura de Milagros. Los Amigos del País no se desaniman y buscan arbitrios para romper la resistencia del clero, juzgando su integración al Cuerpo imprescindible. Tudela no proporciona ejemplos con- 
cretos de mismo carácter: “Por orden de la Cámara de 3 de agosto de 1780, el Gobierno encargó al prelado del Decanato y a todos los curas que asistiesen a la Sociedad. Pero en cuatro años, sólo asistió tres reces el Vicario General y una o dos veces algunos curas». La Sociedad de SIGüENZA rogó a su prelado la favoreciese con su asociación y protección, pero no consiguió nada. En consecuencia de esta negativa, muchos de los canónigos y prebendados que con sus medios y talentos frecuentaban la Sociedad lo dejaron de hacer e igualmente los demás seculares. Cayó entonces la Sociedad en una postración e inacción que duró seis años. REQUENA señala también como origen de su profunda decadencia, la falta de concurrencia de los curas párrocos y prelados de las comunidades religiosas, "lo que da mal ejemplo». La Sociedad de LA BañEZA se las tiene que haber con varias cofradías que se habían comprometido a contribuir anualmente con una cuota y no cumplen con su palabra desde hace años. Ala EJos desea que los obispos recuerden con frecuencia a sus sacerdotes su deber de alistarse en los Cuerpos Patrióticos. Y cuenca, que acoge a muchos de ellos en su seno, hace serias reservas acerca de la utilidad de su presencia: “Las personas de Iglesia, no hay duda que serían las más oportunas para las Sociedades, si sinceramente se atendiese a su ilustración... Forman una gran parte de la Sociedad, pero no pueden aplicarse ni atender a ella con eficacia y continuación. Prescindimos de las discordias y desavenencias que tienen entre sí. Pero están metidos mañana y tarde en el coro o en sus juntas. No disponen de tiempo para los encargos o comisiones de la Sociedad).

Esta animadversión o despego general, los motiva a menudo el interés material. ZARAgoza denuncia la oposición de varios Cuerpos y particulares que juzgan a las Sociedades contrarias a sus lucros y fines. Por una campaña orquestada de desconsideración, “consiguen que las Sociedades no lleguen al debido grado de prosperidad y perfección de que son capaces, y sabotean todos sus planes. SANTiago alude a «la oposición táctica e indirecta de algunos Cuerpos que creen estos establecimientos opuestos a sus intereses, lo que origina una preocupación muy general contra las Sociedades). Ya estudiaremos en otro capítulo hasta qué punto aquellos roces y desaires perjudicaron a ciertas Sociedades, manteniéndolas en un estancamiento e impotencia deplorables y arruinándolas a menudo.

Las Sociedades pues, despiertan demasiadas veces hostilidad, desconfianza y rencores. Tienen que luchar contra muchas corrientes destructoras que socavan su frágil y complejo edificio, lo que no facilita su labor y revela que no todo el país estaba sediento de luces y de progresos, sino que 
al contrario, se aferraba a sus antiguos privilegios y costumbres ancestrales, recelando cualquier novedad y más aún reforma.

\section{4) Imperfección de los Socios}

Lo que explica también las insuficiencias de las Sociedades, es la imperfección de sus individuos. Empresas humanas, las Sociedades no pueden escapar a las debilidades inherentes a su naturaleza. Los redactores del informe de sevilla, con buena dosis de filosofía y hasta de pirronismo, no tienen la ingenuidad de asombrarse de esta verdad. Las Sociedades sufren las crisis y "la natural inconsistencia de las cosas humanas; no todos sienten por igual el estímulo del amor a la patria, de la caridad y beneficencia». Creadas por el hombre, son, sin remedio, imperfectas.

El hombre, por esencia, es superficial y voluble. Cual falena por la luz del quinqué, se deja alucinar por el oropel de la novedad. "Unos llevados de su celo, otros de la novedad se alistaron', observa oviedo. En tudela, Ta iniciativa del marqués de San Adrián y demás fundadores es acogida con entusiasmo; pronto se completa el número de 24 socios numerarios y otros muchos no numerarios. Pero, «esa llamarada de afición... fue tan efímera que al punto desapareción, cediendo el campo al desafecto y a la malicia. Esta misma inconstancia la subraya LA MATRItense: “El espíritu de novedad en los principios condujo a muchos a incorporarse en estos Cuerpos. Pasada la primera fermentación, no ha sido tan frecuente el concurso de los individuos. Ambas cosas están en la naturaleza física y moral del hombre. Las ideas nuevas causan placer, pero lo pierden cuando nos familiarizamos con ellas) ${ }^{29}$.

Idéntico análisis hace cuenca: «Fueron muchos los que se alistaron al principio. Han visto que semejante ocupación sólo produce incomodidades, trabajo y también desazones. Por eso se entibiaron y desmayaron».

Por cierto, tienen los dirigentes su parte de responsabilidad en esta desfavorable evolución. No disponiendo de más recursos en la mayoría de los casos que de la cuota anual, generalmente 60 u 80 reales por cabeza, -cuando no 48 como en MEDINA DE RIOSECo-, las Sociedades tratan de reclutar el mayor número posible de contribuyentes para arrancar. Este enrolamiento masivo, que en ocasiones cobró visos de «leva forzosa», no facilitó al Cuer-

29 S. E. M., leg. 79/10. 
po colaboradores de vocación profunda. Se vio en ovieno en donde varios sujetos «incluídos en las listas sin su acuerdo, se negaron a la paga de la contribución» y desertaron. La matritense confiesa que hubo mucho desorden en la admisión de socios. Fue preciso franquear la entrada a muchos zánganos con la única mira de que contribuyesen. Es así cómo, según las propias declaraciones del socio D. Manuel Ambrona, el último catálogo arroja la cifra de 330 socios, de los cuales más de la mitad no hacen nada ni tienen la menor utilidad). Se ha concedido por la constitución al individuo demasiada libertad de asistir a no a los trabajos de la Sociedad». "Los verdaderos socios útiles muchas veces se confunden en el concepto público con el vulgo de los que sólo sirven para alargar la lista de los contribuyentes de un cuerpo a quien comúnmente desacreditan para hallar disculpa a su propia y personal pereza o impericias ${ }^{30}$. ZARAgoza denuncia a su vez la numerosa concurrencia como embarazosa y perjudicial a la buena marcha de los negocios.

En todas las Sociedades se nota la misma curva descendente: un movimiento de entusiasmo y luego la temible «tibieza», palabra que vuelve machaconamente en todos los informes. Sevilla apunta: «En los principios... fueron muy numerosas las juntas que se celebraban, muy eficaz, activo y diligente el celo con que muchos de los individuos procuraban y promovían los asuntos de beneficio público... No tuvo la constante duración que convenía». En su mayoría, los socios son amantes de su comodidad y libertad. "Además, son genios sumamente preocupados y adictos a sus propias opiniones; severos censores de las ajenas, toman pretexto de las lentitudes por no hacer nada o despedirsen. SAN CLEMENTE ilustra el mismo hecho en estos términos: «En los principios, la frecuentación de los vecinos fue casi general... se presentaron una multitud de pensamientos y proyectos, hijos de noble emulación. Unos se realizaron, otros no. Pero, la tibieza... ». Tibieza que puede revestir formas diversas: falta de concurrencia a las juntas (requena, soria, valladolid), indiferencia, indolencia, escasa inclinación y celo por la causa pública, rechazo de responsabilidades (TOLEDo, vélez mÁlAga, CUENCA, etc.). El mal parece casi general y conocido del Consejo, ya que el argumento sirve de fundamento a su circular.

Esta desafección y falta de aplicación en muchos de los que se alistaron procede de diferentes causas. A veces, la provoca la contribución exigida a los socios. Entre los estorbos que encuentra Lugo, señala además de la

30 S. E. M., leg. $82 / 26$. 
tibieza de los socios la repugnancia que experimentan otros que ofrecían serlo, a pagar la contribución anual de 80 reales, "pretextando el desembolso que sufren con la nueva administración de rentas provinciales». En REQUENA, «ciertos hacendados — con ser pudientes - se niegan a pagar la muy corta contribución... y varios socios no contribuyen». En cuenca, «muchos socios no abonan la cotización de 60 reales, encontrándola excesiva y unos proponen que haya socios de 60 reales y otros de 30 . Oviedo se muestra pesimista en este aspecto. «El número de socios continuará disminuyendo, pues los nuevos tributos recién establecidos [en la provincia] han causado un alza general de precios y los 60 reales anuales parecen una contribución desorbitada que equivaldría a un duplo o más en cuanto a los frutos o productos del país». Zaragoza se queja de la misma actitud. entre sus individuos: “Hay Socios alistados que no contribuyen con la modesta pensión del doblón anual ${ }^{31}$ y ocupan indebidamente un lugar en el catálogo». "Muchos consideran, relata oviedo, el alistarse y contribuir como mera obra pía y tienen ya bastantes objetos en que ejercitar su caridad: mendicantes, enfermos, viejos, viudas, jornaleros y artesanos sin trabajo, labradores. Tanta necesidad agobia a los vecinos, en años regulares y malos como el pasado y el presente, y dejan de alistarse».

Frente a esta negativa de muchos socios de satisfacer la cuota señalada ¿qué recurso tiene la Sociedad? Ninguno, contesta cuenca. "No tiene facultad para obligarles al pago, pues el Consejo suprimió toda cláusula de apremio en los Estatutos. Sólo se tacha el nombre del recalcitrante a los seis meses. Hay quien propone dar cierta publicidad a la lista de socios que rehúsan abonar su cuota. Pero otros observan que este medio resultaria posiblemente contraproducente y no haría sino introducir la enemistad y la guerra en el seno de los Cuerpos Patrióticos. Produciría gravísimo disgusto y tal vez sea ése el modo de aniquilar la Sociedad en vez de aumentarla». La consecuencia de esta actitud es la falta de fondos en la caja de la Sociedad, porque ala renta reducida a la contribución voluntaria anual de algunos socios fieles no basta para cumplir los múltiples cometidos de la Sociedad, una vez deducidos los gastos ordinarios), comenta nuevamente CUENCA.

Poco amigos de dar su dinero, los socios en su mayoría, decepcionan a los responsables por otros defectos graves: poca asiduidad, rutina, pereza, incapacidad, falta de espíritu cívico.

31 El doblón sencillo era una moneda imaginaria de valor de 60 reales (Dicc. Acad.), 
E1 absentismo de muchos en las juntas entraña otra consecuencia nefasta: los que permanecen en su puesto pierden el tiempo buscando arbitrios para remediar esta doble falta, observa cuenca, y la Sociedad no puede realizar lo proyectado. En REQuena, la falta de concurrencia de los socios y el desaliento de los plantadores hunden el proyecto de fomentar la manufactura de sedas que tenía muy buenas condiciones en la comarca, disponiendo de un vasto terreno de regadío donde se pudiera plantar un millón de moreras. La Sociedad pide al Consejo que compela a los hacendados a contribuir para el estipendio de los celadores de campos y plantíos y a plantar en cada almud ${ }^{32}$ seis moreras en cuatro o seis años.

De la rutina y luces insuficientes, se quejan LA GOMERA, ALAEjos, y LEón. «El origen de la tibieza, dice VÉLEz MÁlAGA, hay que buscarlo en la poca ilustración. La gente no tiene conciencia de la obligación con que nació todo hombre de dedicar una parte de sus más serios cuidados al beneficio común». Campan por sus respetos el pernicioso egoísmo y la indiferencia. Con las propias palabras, LEón fustiga «la falta de instrucción en los socios de primera hora y la indiferencia al bien público» y expresa su desaliento al ver que no se consiguen grandes ventajas. Oviedo puntualiza mucho más: los conocimientos imprescindibles en los socios son los de Economía política: “Antes de la formación de la Sociedad, era voluntario y nada preciso el estudio de la Economía política. Por ello fue corto el número de socios. Pero la creación de la Sociedad no ha mejorado el ínfimo concepto que antes podían tener de dicho estudio y conocimiento... Pensaban que de ello no podía seguir a sus personas o familias honras o provecho». La inacción de muchos socios, se explicaria, pues, más que por la pereza, por la falta de preparación adecuada. Santiago afirma: «Lo que se ha hecho hasta aquí se debe solamente a la aplicación y constancia de un pequeño número de individuos, sobre quienes cargan todas las tareas de su institutom.

Otros hay que podrían ser útiles, pues tienen las luces requeridas, pero no quieren asumir responsabilidades o se quedan en la sombra por excesiva modestia. Explica el socio Ascargorta de la matritense: «Es verdad que hay pocos individuos útiles. Pero hay más de lo que se cree. Si cada uno eligiese formar parte de alguna comisión, todos procurarían acreditarse y se conocería la utilidad de muchos que hoy se ignora. El Director no puede conocer la aptitud de todos ni aventurar los expedientes a la suerte.

32 Almud: espacio en que cabe media fanega de sembradura. (Dic. Acad.). 
Por eso, cuenta con los que conoce... y los que carecen de ciertos accidentes recomendables pasan por destituídos de suficiencia... ${ }^{33}$. El dictamen de D. Diego Notario completa esta observación: «Es cortísima la porción de socios que se dedican al despacho de los expedientes. Es necesario hallar algún medio de ponerlos a todos en movimiento continuo. Falta en los Estatutos alguna providencia que encamine a poner clases e individuos en acción. Los socios no desean otra cosa que emplearse. Hay una gran variedad entre ellos, capacitados para tareas y también prácticos en muchos oficios $\mathrm{y}$ artes) ${ }^{34}$.

Santa Teresa denunció el peligro que representa «la negra honrilla» para el progreso del alma individual en el camino de perfección. Asimismo hay quien denuncia el peligro que el pundonor representa para el desarrollo de esos Cuerpos Patrióticos. La sociedad toledana en la que parece predominar un espíritu aristocrático y elitista, no quiere que los oficios sean electos: «El amor propio, dice, hace que las elecciones resulten muy molestas a los que quedan depuestos o no empleados». Hay que evitarlas. Algo parecido expone zamorA: "Como cada individuo contribuyente se juzga autorizado a que se apruebe o siga su propuesta, la dificultad de admitirse aun al ensayo, a causa de los pocos fondos, ha podido retraer a varios juzgándose desairados o en la imposibilidad de que se logren sus proyectos, que cada individuo juzga los más ventajosos».

No todos los análisis recogidos en los informes son negativos. A veces los firmantes, al par que perspicaces, se muestran benévolos para con sus semejantes y echan la culpa del estancamiento de las Sociedades a las instituciones y al Gobierno más que a los hombres. La Clase de Industria de Madrid, tras reconocer que no todos los socios toman parte en las tareas del Cuerpo, añade: "Pero hay un número suficiente y competente para el despacho de los expedientes. Este mismo es corto, comparado con el que consta del catálogo, porque sin contar con los ausentes, malos y agregados, los residentes en Madrid tienen empleos que los ocupan y el desempeño de la obligación de un hombre público no debe posponerse al título de patriota...) A esta causa atribuye el inculpable y corto atraso que padecen algunos expedientes remitidos por orden del Rey y del Consejo a examen de la Sociedad, pues cree que es una cosa muy dura exigir se antepongan

33 S. E. M., leg. $73 / 4$.

34 S. E .M., leg. 73 bis/35. Dictamen de D. Diego Notario, de la clase de Artes y Oficios, Madrid, 1786, 6 folios. 
a las obligaciones en que uno se halla constituido y de que es responsable a Dios, al Rey y al Estado, unos oficios de pura beneficencia, debiendo merecer elogios los conatos de los que sacrifican su reposo y el tiempo destinado al descanso, en obsequio de la causa pública. $\mathrm{Y}$ sin embargo, muchas personas de la primera jerarquía asisten, desempeñan las comisiones, costeando de sus fondos las experiencias y ofrecen premios para promover los objetos del Institutom ${ }^{35}$.

También rompe una lanza en defensa de los socios el Señor Ascargorta: «Nuestro Cuerpo, dice, no se compone ciertamente de hombres vagos; cada uno tiene un destino que le ocupa todo o casi todo el día. El que menos, es pretendiente y no sé si esta necesidad de buscar o mejorar destino ocupa más que los destinos mismos. Ninguno puede abandonar sus obligaciones y cuidados domésticos. Recibamos pues de cada uno lo que quiera y pueda dar') ${ }^{36}$.

Los conquenses, que no viven de ilusiones, están persuadidos, en calidad de buenos discípulos de Rousseau y de Adam Smith, que lo que mueve a la humanidad, no es la virtud, sino el interés, la ambición y la codicia: "Los hombres, en general, no suelen obrar por puro amor a la virtud o celo del bien público. Premios y penas han sido siempre los dos polos sobre que han estribado las repúblicas para que se ejercite lo bueno y no se haga lo malo. Sin esperanza de recompensa temporal, pocos o ninguno quieren sacrificar sus bienes, quietud y conveniencia a beneficio del común». En Cuenca, “la gente clamorea el sumo poder de los dos idolos: Interés y Deleytes» y como no los hallan on la Sociedad, se retraen. La Sociedad intenta convencer a sus conciudadanos, ganarlos a las reformas que preconiza, pero todo en vano: "Buenamente, con paz, con caridad, con atractivos, nos ingeniamos a tentar veredas, pero el ídolo del interés, no sabemos cómo derribarlo... El interés no se satisface mientras no se lo manda la ambición y se lo dice la codicia». Santiago comparte esta opinión: "La gente sólo busca el interés particular. La ocupación desinteresada sólo produce mofa y escarnio. Hay que fomentar el patriotismo»).

Es evidente que una empresa como la de las Sociedades Económicas que estribaba esencial o únicamente en el sacrificio abnegado de inteligencia, bienes y tiempo, en el amor y la caridad, en la gran idea del servicio a la Patria, representaba un verdadero apostolado laico, y suponía para

35 S. E. M., leg. $79 / 10$.

36 S. E. M., leg. $73 / 4$. 
acometerla almas también grandes y nobles, encendidas por la fe en el Progreso. Pero no todos los hombres tienen madera de apóstol y en aquel contexto, no podían menos de resaltar cruelmente y de entorpecer la buena marcha del Cuerpo, todas sus deficiencias y pequeñeces. Y más cuando tropezaban con insolubles problemas de dinero.

\section{5) Falta de fondos}

Las carencias en los socios, por cierto, son perjudiciales, pero la carencia de fondos es otro factor grave de decadencia.

Si hay un punto en que, a pesar de su diversidad, las Sociedades coinciden en el análisis de las causas de su decadencia o escasa prosperidad, es la falta de medios o de caudales. Todos señalan el hecho, las diferencias son sólo de matices.

Hay Sociedades verdaderamente indigentes, como sigüEnZA «casi perdida por su pobreza), y sin embargo sabe que en su distrito queda mucho dinero amontonado e inútil: 217.514 reales en la Tesorería de la Catedral, procedentes de vacantes de la mitra; 46.391 reales de impuestos en la Tesoreria de Guadalajara remitidos por la ciudad del impuesto de ocho maravedíes en cada arroba die vino y 263.905 reales destinados a obras pías. Desprovista de todo, denuncia la Sociedad el escándalo de este dinero que no trabaja y «está parado». Quisiera aplicar parte de él para cuotas de maestros y con la otra parte, fundar un Montepío para colonos y campesinos. La situación financiera de la Sociedad está a tenor de la de los habitantes: «Son tan pobres los labradores de este país que, faltos de medios, dejan $\sin$ sembrar las tierras».

Tampoco es rica vélez málaga, cuyo Cuerpo Patriótico “desde su origen no ha tenido más auxilios que la contribución anual que se impusieron los mismos socios y eventualmente las limosnas y gratificaciones. El total asciende a 37.890 reales por año. "La falta de fondos es la causa principal que la decae», confiesa la Bañeza. La Sociedad de yepes no ha recibido hasta el presente un centavo ni de los Propios - aunque tienen cuantiosos caudales_, ni de otra parte, «ni presume de donde le venga», y tan deplorable situación basta para explicar su decadencia. VALLADoLid reclama "cuna pingüe dotación», añadiendo: "La dotación es sin duda el principal medio de fomentar y revivir las Sociedades». Alafjos repite como un eco: "Tenemos gran necesidad de fondos». Para mantener lo que realizó a duras penas, tiene que mendigar de puerta en puerta. YePEs opi- 
na que la causa de su decadencia "ha sido la falta de un fondo suficiente y preciso para su establecimiento».

Es forzoso incurrir en repeticiones, pues todos se expresan en idénticos términos: “No pueden admitirse muchos de los proyectos, por falta de medios» (ZAMORA); “El dinero no viene. Ocupa el primer lugar la falta de fondos» (CUENCA); “Faltan los caudales para ensayos, premios y gastos» (LEóN); “No cuenta con la munificencia de un prelado y, necesitada de fondos, clama al Rey... Todas sus dificultades son de dinero» (Lucena). Usuna, en cambio, puede contar con la generosidad del Duque que le da 24.000 reales al año y varias limosnas; sin embargo, habla de la «tenuidad de sus recursos». Ovieno "no tiene fondo efectivo y cierto: sólo dispone de las contribuciones y de algún donativo».

Incluso la Sociedad que se suele dar por modelo a todas las demás y que sirve de censor regio a todas las existentes, la matrrtense, no dice otra cosa: “No tiene fondos», y más adelante puntualiza: «no dejan de aumentar los negocios y no los fondos. Lo que se llama decadencia ha sido imposibilidad de hacer mayores progresos por falta de medios y auxilios». Por su parte, la Clase de Industria señala que «los cortos fondos con que cuenta la Sociedad no le permiten abrazar objetos grandiosos que no se deben esperar de un establecimiento sin autoridad, sin influjo y sin los precisos auxilios ${ }^{37}$. En otra ocasión, recuerda LA Matritense al Consejo que no tiene más fondos que las inciertas y voluntarias contribuciones de los individuos numerarios que no son muchos y no puede por lo tanto acometer "empresas vastas y magníficas». Ya hemos dicho que la cuota anual resultaba gravosa a no pocos socios y su recaudación se hacía difícil en muchos sitios. Muy escasas son las Sociedades favorecidas con un apoyo económico y despiertan la envidia de las demás. Cuenca advierte muy resentida: "Si los arbitrios de MURCIA y vergara pudiera prometérselos nuestra Sociedad, poco tendría en que fatigar su discurso. Pero rasgos heroicos de liberalidad y magnificencia como los que contienen estos dos ejemplares, más son para admirados que para prometidos».

En resumidas cuentas, la insuficiencia de caudales que raya a menudo en penuria es el lote común de los Amigos del País. Al sentimiento de impotencia que despierta en ellos la falta de recursos económicos, se añade la impresión de una inconsecuencia, de una injusticia por parte del Gobierno que explota su patriotismo y su desinterés, sin darles los medios de

37 S. E. M., leg. 79/10. 
realizar lo que él mismo anhela y ellos sugieren, y por fin los critica y los tacha de “decadentes», si no consiguen éxitos clamorosos en unas tareas que ha dejado a su cuidado y que le nncumbía a él asumir. Así descubrimos otro vicio de fondo de las Sociedades tal como se idearon, ambiciosa fábrica desprovista de las estructuras elementales, destinada a enfrentarse con las duras y concretas realidades cotidianas, cuando ella misma era por naturaleza frágil y quimérica.

\section{6) Trabas gubernativas y administrativas}

Ahora bien, desprovistas las Sociedades de dotación fija y de recursos económicos, ¡contarán por lo menos con la ayuda del Gobierno y del soberano? Encontrarán en ellos un apoyo incondicional para sus proyectos dirigidos al bien común? Sin duda, pues la misma Circular del Consejo recuerda que «el Rey les ha dispensado a todos su Real protección y mandó recomendar ... a los Prelados, Comandantes generales y Justicias del Reyno que promoviesen los expresados Cuerpos Económicos». Así, las Sociedades, mal acogidas por el público ignorante o poco ilustrado, a cuyo beneficio se desvelan desinteresadamente, se sentirán respaldadas por la jerarquía y los estamentos rectores del pais.

Por desgracia, ya sabemos que esta visión teórica no siempre corresponde a la realidad. Muchas Sociedades notan con amargura en sus informes que esas mismas autoridades, religiosas, militares y judiciales a quienes había mandado el Rey las auxiliase en sus operaciones, se les vuelven con frecuencia hostiles, imitadas en eso por no pocos responsables municipales, alcaldes o regidores. Pero hay más. El propio Gobierno, ese mismo Consejo que tan activamente en un principio fomentó las Sociedades y vigiló atentamente sus primeros pasos, va poniéndoles ahora trabas insalvables, colocándolas a veces en situaciones muy molestas, incluso dramáticas y desesperadas.

En Cuenca, los socios chocan con la municipalidad. Su ambicioso proyecto de fomentar el regadío de la Vega de Tordera encuentra tan fuerte oposición en los Propios y el Ayuntamiento que terminan por retirar el expediente. Tampoco ayudan los jueces conquenses. Anhelaba la Sociedad fundar una escuela de primeras letras. Los comisionados meditaron largos meses aquel problema y formaron planes. Pero, creyendo los maestros ya en ejercicio que aquella creación sería su ruina, acudieron a la justicia. Los buenos deseos de la Sociedad se quedaron en ciernes y no se hizo finalmente nada. Sigüenza propuso la creación de otra escuela en el arrabal, 
por no haber en la ciudad más que una, dotando al maestro de los Propios y Arbitrios. Se negó la ciudad. Los socios tudelanos quieren establecer un Seminario de Educación y para eso piden el Colegio de los ex-jesuitas. El Ayuntamiento no les hace caso; ni siquiera contesta a su oficio. Del mismo Ayuntamiento, reciben otro desaire. Le envían un cirujano que ofrece curar graciosamente a todos los impedidos del pueblo y visitar a los recién nacidos “imperfectos», con arreglo a un decreto del Gobierno. Pero el Ayuntamiento hace oídos de mercader, y no le nombra, privando al público de aquel socorro. Segovia tiene que entendérselas con los privilegios de los Gremios y sale derrotada. Cuenta en su informe cómo un tal D. Antonio Torrecilla, maestro fabricante de curtidos, había inventado un método para curtir sin dejar la piel tanto tiempo en el noque. La novedad provocó una violenta reacción del Gremio, de sus veedores y del Intendente. Tal actitud disgustó muchísimo a la Sociedad y se quedaron desalentados los artesanos al ver que "si uno intenta salir de la ruta antigua y quiere discurrir en perfeccionar su oficio, se encuentra envuelto en mil enredos y expuesto a mil pleitos, sin embargo de hallarse protegido por la Sociedad y de tener licencia del juez para sus experimentos». La mísma Sociedad tiene que lamentar también una mala pasada de la Real Junta de Comercio. En 4 de noviembre de 1785, remitió a dicha Junta el primer tomo de sus Actas que contenía una memoria sobre la necesidad de formar nuevas ordenanzas para la fábrica de paños, como lo venía mandando el Rey desde hacía 16 años. Agradeció la Junta en términos muy elogiosos el envío del obsequio, pero al mismo tiempo representó al Trono para privar a la Sociedad del privilegio concedido por el Rey de cobrar medio real de derecho por arroba de lana lavada y un cuartillo en la sucia, que se extrajesen de la provincia para reinos extranjeros. La Junta de Comercio se salió con la suya y obtuvo para sí misma la concesión de aquel arbitrio, despojando a la Sociedad, que se vio de pronto trágicamente empobrecida y desalentada. Unos meses después, una Real Cédula privaba a la Sociedad do su antiguc derecho sobre la Iana, cuyo producto se invertiría en adelante en las escuelas de hilazas de lana. La medida provocó la deserción de varios socios. La Sociedad representó entonces al Rey quien le restituyó su privilegio, pero la Junta de Comercio impuso su condición de aplicar aquellos ingresos a las escuelas de hilazas. Ya no pudieron tos socios disponer de aquellos ingresos a su antojo y para las necesidades más apremiantes. Todos fueron de parecer que la actitud de la Junta de Comercio "procedía de algún informe siniestro». En las islas Canarias, tal vez porque se sienten protegidos por la distancia, los jueces hacen de su capa un sayo. Las quejas de los insulares son muchas. Hay infinitos abusos 
que no corrigen las autoridades. Todo lo que emprende la Sociedad de LA Gomera fracasa, sean pastos comunes, - porque chocan con los intereses encontrados del Común y de unos nobles-, conservación de montes, reparto de aguas o roturas de tierras reservadas al ganado. Los vagos y viciosos abundan, tolerados por la justicia. En GRAN CANARia, la situación es aún peor. Su informe es una larga retahíla de empresas frustradas. Si no prospera el proyecto de pesca de ballenas, les que lo hundieron unas medidas administrativas. El fomento de pesca de vivero para abasto del pueblo encontró una fuerte oposición. Con el fin de perfeccionar el curtido, facilitó la Sociedad el establecimiento de dos zapateros portugueses muy duchos, pero una providencia de la Audiencia lo destruyó todo por un medio indirecto. La Sociedad da otros ejemplos de la enemiga con que la persigue la Audiencia. Para atajar los progresos del mal de elefancía que cunde en la isla «por la libertad con que los dañados tratan y comunican con los sanos por casamientom, propuso la edificación de una leprosería para proteger al público de la contaminación de aquellos ienfermos. Pero rechazó la sugerencia la Audiencia. Fracasó también en su intento de rescatar la Casa de Expósitos sumida en tanta indigencia que murieron treinta niños en 1783. Quiso restaurar los montes de la isla, muy deteriorados por talas insensatas y recurrió al Consejo para solicitar la denegación y revocación de datas en los terrenos del Monte Lentiscal y Montaña de Doramas. Entonces, el Consejo pidió un informe a la Audiencia quien no se mostró nada favorable a la pretensión. La gracia obtenida por el hospital de San Lázaro para romper y cultivar 300 fanegas de tierra de la aludida Montaña de Doramas, parecía a todos los naturales cosa absurda y perjudicial. Sin embargo, acontra toda esperanza, se vio puesta en ejecución, a pesar de la esforzada defensa del Ayuntamiento y otras autoridades. La Sociedad que miraba a la laz de sus conocimientos lo dañoso de aquel rom. pimiento que destruia por una parte toda esperanza de aumento y replanto en aquel monte y por otra le ocasionaria su desmembración y destrucción, lo representó con la mayor viveza a la Audiencia, al Consejo y al Rey... todo ello sin efecto... y ve cada día con dolor internarse los Lazarinos en la Montaña y muchos particulares imitan este pernicioso ejemplon. Frente a este clima de hostilidad permanente, se desaniman los socios y se retraen otros vecinos de adherirse al Cuerpo. Segovia se queja con acrimonia del proceder injusto de su Corregidor quien no la auxilia y le pone chinitas en el camino. Quiso la Sociedad fundar un hospicio en 1782, por lo cunl propuso varios arbitrios. Los socios formaron un plan que se inspiraba en los Hospicios de Madrid y Murcia y concluyeron sus tareas en 1783. Pero entretanto. ol Corregidor y el Aytentamiento mandaron a la Superioridad 
informes de contenido desconocido, y fracasó el proyecto. De tantos esfuerzos, estudios y desvelos, no se sacó nada. Concluye Segovia: «Es forzoso que se desanime cualquier Sociedad, al ver como está sucediendo, que sus representaciones vienen a informe de un sujeto, muchas veces enemigo de sus proyectos y alguna, ignorante de la materia», dejando entender que la poca legalidad, la tardanza en el despacho de sus negocios o el radical olvido son siempre de temer en tales casos. Cuenca recoge en una fórmula muy gráfica esta tremenda confluencia de trabas que condena las Sociedades a la impotencia: "Acá toca con la preocupación de las gentes, allá con la necesidad de no pequeños gastos; acullá en celos, privilegios, superioridad, pertenencias, costumbres, en fin por todas partes halla dificultades que absolutamente no es posible vencer».

Mientras unas Sociedades están encantadas por tener a su cabeza como Director a algún Grande de España, hay por lo menos una, donde las cosas andan muy de otro modo: LUCENA. Encuentra en efecto impedimentos insuperables en la persona del duque de Medinaceli. Solicitó habilitar con estanque y hospedería los prodigiosos e inutilizados baños de Horcajo. Pidió licencia al Duque, ofreciéndole intercambios y compensaciones, o rogándole hiciese aquellos arreglos él mismo. No tuvo esta súplica ni contestación ni efecto. Nos relata otro incidente. Intentó un socio erigir una fábrica de curtidos en un baldío realengo. Le negó la licencia el Ayuntamiento y se opuso el Duque so pretexto de ser privilegio exclusivo de su casa. De allí se originó un litigio todavía pendiente en el Supremo Consejo y tuvo que renunciar la Sociedad a su proyecto. "Todas las ideas beneficiosas de la Sociedad, concluye el informe, quedan imposibilitadas por las regalías que alega el Duque». Metida en este callejón sin salida, la Sociedad, en 5 de abril de 1785, "clamó vigorosamente al pie del Trono haciendo ver la situación deplorable del vecindario y suplicando la ayuda del Rey para remover tantos obstáculos». Es de notar que Lucena se dirige al Rey y no al Consejo, posiblemente porque desconfía de la eficacia del Tribunal y ve en el Rey el padre y protector de toda la nación. Varias instancias suyas han sido desaprobadas por el Consejo. De los arbitrios, todos asequibles y nada onerosos para el vecindario, que propuso en 1783, a través de Floridablanca, ninguno ha sido del gusto del Consejo. En 1783 y 1784, hizo solicitudes reiteradas para reunir un hospital de incurables muy mal administrado a otro, con el fin de utilizar el local para escuela de hilazas. Tampoco obtuvo satisfacción.

No es infrecuente que las Sociedades opongan la actitud del Rey, que suponen siempre dispuesío a prestarles auxilio, a la del Consejo, a menudo 
remiso, reacio y remolón. En muchas ocasiones, se quejan las Sociedades de la lentitud, del silencio y de la incomprensión del primer cuerpo del Estado.

La Clase de Artes y Oficios de MADrid aclara que «hubiera trabajado mucho más, si no hubiera visto estancarse en el Consejo y en la Sociedad misma sus más laboriosas producciones» y da como ejemplos varias ordenanzas de gremios, pacientemente elaboradas ${ }^{38}$. Segovia, dechado de Sociedad activa y abnegada, tiene varios motivos de queja contra el Consejo. Pretendía reformar las escuelas de primeras letras y de latinidad existentes entre sus muros. Preparó dos planes muy meditados y apropiados. No obtuvo contestación. En otra ocasión, la Sociedad «recibió del Consejo un sonrojo" por culpa del Corregidor que no transmitió lo actuado. El caso es que, habiendo dimitido un maestro que regentaba una escuela patriótica, los Curadores y la Sociedad proveyeron la plaza en otro sujeto, mientras el Consejo restablecía al antiguo maestro en su puesto. Ia Sociedad se quedó en mala postura una vez más. Sigüenza enumera todos los memoriales que envió a Madrid para sugerir arbitrios que la sacasen de su miseria y que no surtieron ningún efecto. No tuvieron más éxito hasta la fecha las sugerencias de VÉLEZ MÁlAGA: “Ha presentado recursos pendientes en el Supremo Consejo de Castilla para proporcionar fondos con los Patronatos y obras pías de esta ciudad y su jurisdicción que no tienen la aplicación más ventajosa... “Pero nada está hecho todavía y pasan los años. BAeza hizo solicitudes una y otra vez, inútilmente: “Viendo que iban a cortarse los rápidos progresos logrados, la Sociedad representó a S. M. su estado en 1779 , suplicándole se dignase señalar para su dotación el sobrante de arbitrio destinado a costear el vestuario de milicias del rejno». Floridablanca contestó que era imposible y que propusiesen otra solución, lo que hicieron, pero sin resultado. No tiene más suerte la vecina y casi homónima Sociedad de BazA. Pidió al Rey cierto número de pinos de los dilatados montes de la ciudad. Se denegó la pretensión. Solicitó entonces el arbitrio de cuatro reales en cada pino que se concediese a los que no son vecinos, y no sabe aun cuál será la Real resolución. Zamora espera una contestación a sus propuestas de arbitrios sobre caudales de Propios... Entretanto, se contenta con que los asuntos no pasen del raciocinio.

En cuestiones financieras, parece intratable el Consejo. Partiendo del principio implícito, pero aparentemente intangible, de que las Sociedades

38 S. E. M., leg. 82/26, Dictamen de D. Miguel Gerónimo Suárez y Núñez, Madrid, 31 de julio de 1786 . 
han de autofinanciarse, se niega casi siempre a facilitarles dinero. Con la misma intransigencia, actúan otros negociados de la administración. En LA BAÑEZA, “los recaudadores de los efectos del Común, se excusan a la entrega de 50.000 reales que reclama legítimamente la Sociedad» por faltarles el aviso del Consejo de Hacienda a quien están sujetos.

A veces, las medidas que dicta el Consejo se oponen a los verdaderos fines que persiguen las Sociedades y arruinan sus éxitos a duras penas conseguidos. Tal es el caso de vera. Tras mil vicisitudes y unas negociaciones peliagudas, consiguió la Sociedad un frágil equilibrio financiero, merced a la explotación del esparto particularmente abundante en su comarca y no aprovechado. Con estos ingresos, vio la posibilidad de devolver el empréstito de 30.000 reales concedidos por el Rey contra los Propios y que arrastraba como unos grillos. Pero una medida del Consejo promulgada en 1783 echó a tierra todos sus planes comerciales: se prohibió la extracción de esparto en rama a tierras extranjeras y así se cerró toda posibilidad de mercado. La consternación fue general y la Sociedad, un momento en auge, se vio de repente abocada a la catástrofe. No tuvo más remedio que dirigir un nuevo recurso al Rey. En efecto, resultaba imposible vender esparto en el reino de Andalucía, por ser harto corriente en él aquella planta. Tampoco se podía pensar en crear una industria de transformación por falta de puerto por donde despachar aquella manufactura y por la competencia que haría a otras fábricas anteriormente establecidas que se verían obligadas a dar a una mitad menos sus productos. Además, la implantación de una industria de esparto suponía invertir fondos de los que carecía completamente la Sociedad. Enterándose de que la Real Hacienda mandaba un sujeto para hacer gran acopio de esparto, confió un momento en que podría negociar con él todas sus reservas de esparto, sacando por cada quintal dos reales de beneficio. Con este dinero, pensaba abrir un camino de mampostería desde Vera hasta el lugar de la Garrucha, distante más de legua y media y que quedaba anegado e intransitable cada invierno por las crecidas del río Anteas. Pero se llevó otra decepción mayúscula: el delegado de la Real Hacienda hizo sin avisar todo su acopio en Murcia y Cartagena. La Sociedad vio con gran disgusto cómo iban a perderse 1500 “millares» ${ }^{39}$ de esparto, cuyo valor intrínseco pasaba de sesenta y tantos mil reales. Después de una súplica al Ministro de la Hacienda, en octubre de 1783, logró deshacerse de su esparto, pero perdió en la operación un real de beneficio 
por quintal, o sea recogió sólo 22.500 reales en vez de los 45.000 que esperaba para llevar a cabo sus proyectos.

Segovia ve también todas sus empresas periclitar por culpa de la dejadez de los poderes centrales. Quiso promover la fábrica de paños. Como las ordenanzas del gremio frenaban el adelantamiento, propuso nuevas ordenanzas. Cinco años pasaron sin contestación del Consejo. Recurrió al Ministerio por la vía reservada, presentando como testimonio de la calidad de sus manufacturas una pieza de paño treinteno ${ }^{40}$ superior al de Sedán. Todo siguió igual. Esta actitud de indolencia, por no decir de incuria, se repite entre las autoridades locales. Los Amigos del País segovianos se preocupan por la higiene de la ciudad, estudian un plan de limpieza de las calles, se leen memorias y se reparten premios sobre el tema. Floridablanca, convencido de la necesidad y urgencia de esta obra de salud pública, encarga su aplicación al Corregidor. Pero éste, «desmayó pronto» y la novedad duró poco, “así como sucede con todas las demás providencias nuevas, a no ser que su observancia no dependa de los jueces subalternos).

REQUena se queda tan mal parada como la capital castellana en sus reivindicaciones. Representa por mano de Floridablanca pidiendo una Casa Hospicio para la recolección de mendigos, haciendo ver al mismo tiempo la posibilidad de crear un hospital de bastante capacidad con su iglesia. Existen los locales, existen las abras pías que habría que aplicar a estas dos empresas benéficas. También intercede en favor de los maestros de latinidad y primeras letras, sugiriendo dotarles con las rentas de otra obra pía. Ninguna de las dos peticiones surte el menor efecto.

Cada Sociedad hace pues la dolorosa experiencia de múltiples desazones. Tantas demoras, tantos silencios prolongados, tantas maniobras falsas, desaires, rechazos, se interpretan negativamente en las Sociedades. Todas claman su falta de protección y su desamparo por parte del Estado. E1 Gobierno no las respalda en sus empresas, no tiene con ellas identidad de miras, o por lo menos, lo deja suponer su actitud. Se sienten defraudadas, desazonadas, al ver sus esfuerzos estériles, su labor abnegada y sus propuestas condenadas al olvido, al desprecio o al fracaso. Nada extraño, en tales condiciones, que su llamarada de entusiasmo primero, nacida de un deseo sincero de hacer obra útil para el Estado, se haya apagado al comprobar que muy contadas veces, se satisfacían sus deseos, se acogían sus sugerencias y se reconocían sus conatos y sus méritos. 


\section{7) Ingratitud del Gobierno}

Ya hemos dicho que los informes remitidos al Consejo por las Sociedades presentan una enorme variedad, con diferencias de perspectiva entre unos y otros muy notables. Pero coinciden en ciertos puntos: la inexistencia de fondos y la falta de reconocimiento de sus méritos. Esta absoluta unanimidad en el planteamiento de un mismo tema nos lleva a preguntarnos si las Sociedades no se concertaron antes de obedecer la Circular. Pero lo más probable es que ya con anterioridad, habían debatido este tema y que todas tenían motivos de quejas y deseos de expresar claramente su rencor. No iban a desperdiciar la ocasión que les proporcionaba el Consejo.

Para la Sociedad de SAN CLEMENTE, constituye este punto el meollo de su contestación: “...El origen de la decadencia procede de la ninguna compensación o premio honorífico para distinguir a aquellos buenos patricios que sacrifican sus tareas y caudales en servicio y adelantamiento del público». A cambio de su abnegación, ¿qué recompensa reciben los socios? Buenas palabras, a veces, y nada más. En el caso privilegiado de LA MATritense, el trabajo que han exigido de ella, ha sido su único aliciente: "La confianza que el Gobierno ha depositado en ella, nota D. Manuel Sixto Espinosa, cometiéndole de continuo el examen de importantes asuntos y expedientes es acaso el único principio de vida que la mantiene en ser y en una posición capaz de exigir de sus individuos sacrificios de toda especie sin proporcionada recompensa) ${ }^{41}$. Evidencia que encarece el socio Ascargorta con estas palabras: "Hacemos profesión de patriotismo, pero nadie ha recibido otro estímulo que el de su patriotismo» "2. "Estímulo», vocablo importante y de sabor amargo en boca de hombres que dedicaban parte de su tiempo y caudal en proponer premios y repartirlos; vocablo importante también en la ideología de la Ilustración, como la palabra “premio». «El premio evitará la tibieza. Las personas celosas abundan en el Cuerpo. Pero el premio es un estímulo necesario para hacerlas más celosas» ${ }^{43}$.

Opina lo mismo valladolid, aunque hace más hincapié en la especie y con mayor abundancia de detalles: "El desnudo amor a la Patria no basta para que los hombres abandonen sus propios negocios para dedicarse a la asistencia de las Juntas y desempeño de las comisiones. El más héroe, espera cuando menos, la gloria. Creer que los individuos de la Sociedad

\footnotetext{
41 S. E. M., leg. $82 / 48$.

42 S. E. M., leg. $73 / 4$.

43 Ibidem, idem.
} 
han de esmerarse en cumplir con los cargos deste nombre y olvidar no poco tiempo los suyos propios por sólo el celo patriótico y sin esperar una verdadera recompensa, es entusiasmo. De aquí es la necesidad de premiar las fatigas de estos sugetos a proporción de sus desvelos en los trabajos sociales y distinguir su mérito». Cuenca, frecuentemente sentenciosa, afirma: «Sin esperanza de recompensa temporal, pocos o ninguno quieren sacrificar sus bienes, quietud y conveniencias en beneficio del común». Las cosas andarían de otra manera, escribe JEREz DE LA Frontera, “si el Rey distinguirse con privilegios, honores y premios los Cuerpos Patrióticos y sus miembros...).

«Esta circunstancia hará trabajar a muchos con gran celo y será muy justo el que premie S. M. a los que se esmeren en beneficio público y prosperidad de sus vasallos», subraya León. También aboga la sociedad LUCENSE por la concesión de unas recompensas "puesto que los socios sacrifican su caudal en beneficio público. Sería el aliciente más poderosom. Osuna desearía que «los aplicados tocasen algún estímulo, premio honorífico de sus justificadas tareas»), lo que también pide VAlladolid, pues opina que es imprescindible (premiar y recompensar las fatigas de los oficiales». Para ello, sugiere el socio matritense D. Miguel Jerónimo Suárez y Núñez, convendría "hacer presente al Ministerio que, siendo el honor y el interés los dos polos en que se mueve la voluntad del hombre, es preciso proporcionarle algún desahogo por estos medios oportunos, ya que voluntariamente abandona su tiempo y su dinero en servicio de la Nación» ${ }^{44}$. Otro madrileño observa que (cel hombre más modesto y el Cuerpo más desinteresado y más imbuído de patriotismo, jamás pierde de vista su honrada ambición de gloria que le hace arrostrar los mayores riesgos, abrazar las fatigas y trabajos más penosos y vencer dificultades: esta gloria está cifrada en la unánime y común aprobación del proceder y conducta de los sujetos elogiada y admirada por el públicos ${ }^{45}$. En su informe, recuerda el Censor de LA matritense (el estímulo que inspira la dulce confianza en los individuos de ver premiados sus afanes y vigilias. El interés, sea deseo de gloria, de comodidad o de fortuna, es el resorte que mueve el corazón humano». Las personas instruidas y arraigadas que componen la Sociedad, opina por su parte la Clase de Agricultura, no necesitarian más recompensa que la gloria de cooperar con el Gobierno a la felicidad pública; sin embargo, es. lima que el Gobiemo adebería premiar a los que se distinguen en este

44 S. E. M., leg. $82 / 26$.

45 Ibidem, idem, parecer de D. Bernardo Hidalgo, Madrid, 31 de julio de 1786. 
glorioso trabajom ${ }^{46}$. MADrid pone el colofón a esta serie de pareceres en estos términos: «Las recompensas y los premios a los individuos beneméritos es uno de los medios que el mayor número de socios contempla más eficaces para animarlos al trabajo. En todas las monarquías, ha sido un termómetro seguro de los grados de actividad y celo, la mayor o menor remuneración...»

Esta argumentación, encaminada a recabar recompensas para los socios, es sin disputa posible, muy convincente, no sólo porque se apoya en una verdad psicológica general e indiscutible, a saber que el honor y el interés son dos de los más poderosos motores de la actividad humana, sino también porque le da especial fuerza una circunstancia particular: el Rey había prometido premiar a los socios más celosos. Pese a esta promesa, ovieDo está poco inclinada a creer que las recompensas reales puedan redundar en beneficio de la gente de provincias, demasiado alejada de la Corte para descollar: "La oferta de atender a los que se esmerasen, no es eficaz en provincias, porque el mérito queda desconocido, a la diferencia de la Corte donde proporciona ascensosn.

La misma circular del Consejo alude brevemente a ese compromiso deI Soberano: «...ofreciendo... atender a los individuos que más se distinguiesen en sus tareas». Pero han transcurrido once años y la promesa no se cumplió. Es lo que recalca, no sin mal disimulado rencor, LA BASCONGA$\mathrm{DA}$, al señalar «la conveniencia de premiar a los que sobresalen en las Sociedades». El Rey, dice, prometió (distinguir con mercedes a los vasallos que se diesen más a conocer por su celo y talentos) y prosigue con un sarcasmo: “Por ejemplo, ningún individuo de LA BASCONGADA obtuvo el menor premio».

Todas las Sociedades tienen aguda conciencia de que el gobierno no se ha portado decorosamente con la decana de las Sociedades. Piensa la Clase de Agricultura de MADrid que (el Gobierno debe de justicia honrar, promover y premiar a los que se distingan, pero que los Amigos del País no deben esperar recompensas personales. Doce años de experiencia bastan para convencerse de que el Gobierno no se acuerda de nosotros ni de recompensar nuestras penosas tareas... No olvidemos que el conde de Peñaflorida, fundador y Director de la sociedad BASCONGADA, empleó sus luces, su crédito y sus caudales y lo que es más, expuso y sacrificó a su primogénito a beneficio de su patria... y murió sin una señal de aprecio a que parecía

46 S. E. M., leg. $79 / 10$. 
acreedor. Ejemplo pernicioso y que no ha dejado de influir en los progresos de aquel Cuerpo. E1 interés de gloria, distinción o comodidad es el alma del mundo político. Cuando el parentesco, favor, capricho o respetos particulares distribuyen las gracias debidas y arrancadas al mérito, poco se debe esperar de la virtud patriótica, porque... desaparece a los ojos de la más severa filosofía el amor de aquella patria de quien no se espera ningún beneficio. Lo contrario son proyectos aéreos" ${ }^{47}$.

Palabras duras, atrevidas y condenatorias en las que se traslucen amargura, decepción, inquietud, resentimiento, pérdida de fe y gran porción de sueños rotos. A pesar de tantos sinsabores sufridos, de tantas esperanzas frustradas, tal vez no sea tarde para andar por mejor camino y devolver a los Cuerpos Patrióticos la eficacia que anhelan, pero, juzgan los Socios, es preciso reformar las mismas estructuras de las Sociedades y eliminar todos los obstáculos con que tropiezan a cada paso.

\section{I I}

\section{IMAGEN IDEAL QUE DE SI MISMAS Y DEL SOCIO DAN LAS SOCIEDADES}

Cuando denuncian los males de que adolecen, se refieren las Sociedades, más o menos conscientemente, a un arquetipo ideal, liberado de toda imperfección. Es la sociEdad BASCONGADA la que mejor define la naturaleza de estas entidades, las normas que las rigen y el ideal de perfección y eficacia al que han de acercarse.

Son estos establecimientos, explica, «un efecto de la fermentación del patriotismo en fuerza del cual muchos vasallos recomendables de todas clases y estados se han dedicado voluntariamente a servir al público, sacrificando a tan digno objeto isus tareas, estudios $y$ aun caudales, sin otra mira que la complacencia de tener parte en el mejoramiento de su patria o cuando más el honesto deleite de ser estimados y aplaudidos por motivos tan loables». Por su carácter específico de sumo desinterés, “conviene tratarlos con el mayor miramiento y se arriesgaría perderlo todo queriendo

47 Ibidem, idem. 
dictarles las leyes de su gobierno, por que las acciones voluntarias no se mandan. Deben ser considerados como una delicada planta extraña a nuestro clima que, no habiendo podido prevalecer en el suelo español, por más que lo intentaron con admirable celo muchos hábiles políticos y ministros laboriosos ${ }^{48}$, se vio nacer espontáneamente por una concurrencia de causas que el más sabio gobierno acaso no acertaría a combinar por sí solo... Pero hay el peligro de que si se intenta guiarla contra su natural índole, venga a marchitarse o a secarse de raíz...

«...Las reglas de las Sociedades conviene que sean dictadas y propuestas por los mismos que voluntariamente se sujetan a observarlas, con conocimiento del país que habitan, del genio y circunstancias de sus compatriotas, de las producciones del suelo y demás noticias que deben servir de guía para acertar con el objeto de semejantes constituciones».

A continuación, LA BASCONGADA hace en favor de la (honesta libertad» un alegato valiente que es a la vez un aviso profético para el Gobierno: «Es preciso dejar a los individuos que las componen seguir libremente los impulsos de su celo, mientras no haya ofensa del orden público. El Gobierno no debe entrar en menudencias (duración de los oficiales, número y días de las juntas, etc...) y debe respetar dos principios básicos: no privar a las Sociedades de la libertad que necesitan para el cumplimiento de su instituto; protegerlas y darles toda la estimación e influencia que no sean incompatibles con la naturaleza del estado monárquico. Además, tendrá el Gobierno que hacer ver todo el bien que se puede sacar de tales Cuerpos para que los demás Consejos, Chancillerías, Audiencias y Ministros encargados de adelantar la causa pública se sirvan de ellos como de instrumentos los más eficaces y tanto que no sería fácil inventar otros mejores. En éstos, subraya la Bascongada, se encuentra toda la utilidad de la Obra pía imaginada por Bernardo Ward ${ }^{49}$. Por su medio sería muy fácil

48 Con estas palabras, algo sibilinas, alude sin duda la Bascongada a varios hechos: el origen foráneo de las Sociedades Económicas que con el nombre de Academias, Sociedades de Agricultura o de Ciencias se habían establecido con anterioridad en varios países de Europa; y, por otra parte, a las mejoras económicas que idearon y empezaron a llevar a cabo en tiempos de Felipe V y Fernando VI ministros como Patiño, Campillo, Carvajal y el marqués de la Ensenada.

49 Bernardo Ward, que llegó a ser miembro del Consejo de S. M. y Ministro de la Real Junta de Comercio y Moneda, hizo un viaje de estudios a través de Europa de 1750 a 1754. Compuso la Obra Pía que se publicó en 1750, y luego en 1757 en Valencia. También escribió el Proyecto Económico en que se proponen varias providencias dirigidas a promover los intereses de España con los medios y fondos necesarios para su plantifi- 
y nada costoso al Estado el efectuar la visita general del reino, operación preliminar para la transformación del mismo. Pueden desempeñar todas las funciones que Ward quería confiar a la Junta de Mejoras, y mejor por ser de hombres criados en cada provincia, conociendo bien el país».

Para granada, las Sociedades son «un campo extenso donde desahogar los impulsos de un verdadero patriotismo». En ellas, el pretendiente "llenándose de ideas imparciales o benéficas, se acostumbra a la suavidad, a la discreción, y a la fidelidad con que debe promover a favor del común el servicio del soberano y del Estado».

Ciertos informes recalcan otros dos caracteres que juzgan consustanciales a la naturaleza de Ias Sociedades. Han de ser como las escuelas del pueblo y promover la felicidad pública. Recuerdan que las Sociedades son consideradas por Campomanes como escuelas permanentes que dispensan una instrucción general sobre los medios seguros de restaurar la agricultura y las artes. En cuanto al papel benéfica que les atañe, escribe D. Phelipe Marescalchi [MADrid]: "Considero las Sociedades en calidad de promovedoras de la felicidad pública... porque sin esta circunstancia, juzgo que no deben existiry.

Tal veredicto le lleva a trazar del socio ideal el siguiente retrato: «El socio útil y precioso para estos Cuerpos, para el país, para el monarca mismo, es el ciudadano libre de preocupaciones, que no admite una opinión porque es corriente como una moneda, sino porque se halla convencido de su verdad o verosimilitud por la reflexión más asidua. Es el que tampoco se deja arrastrar por el vicio opuesto, por el prurito de desaprobar todo cuanto ve establecido. Es el hombre independiente que no se ve precisado a contemplar a nadie. Es el que por sus conexiones, relaciones, modo de vivir y conducta, manifiesta que no tendrá más interés en que las resolu* ciones de las Juntas salgan de un modo que de otro. Es el hombre esforzado que sabe sujetar sus pasiones personales o las del Cuerpo politico en que está inscrito a la generosa pasiốn de la gloria $\mathrm{y}$ de la alabanza... Es el que, rico de conocimientos económicos y dotado de sensibilidad patriótica, biene talento y celo para dirigir sus dictámenes a la mayor felicidad posible repartida en la porción más numerosa de los conciudadanos. EI hombre justo y tenaz en su propósito que corona con la constancia el mé-

cación. Escrita en 1762, esta última obra se publicó después de su muerte. La segunda edición, Madrid, Ibarra, 1779, en $4 .^{\circ}$, XXVIII-400 págs., contiene también la Obra Pía (págs. 320 y sigs.). 
rito de sus empresas. Esa es, Señores, la imagen del ciudadano que debe ser sociom ${ }^{50}$.

Partiendo de todas estas premisas, estamos en condiciones de esbozar ya el perfil de la Sociedad ideal. Tendría dos vertientes complementarias: una, filosófica, administrativa la otra. Integrada por un número limitado de individuos seleccionados, todos aptos para la observación, la meditación, la interpretación objetiva de los hechos económicos, sería una entidad en la que se cultivaría el espíritu crítico, aplicándolo sistemáticamente a todas las leyes, tradiciones, creencias, hábitos, usos y costumbres de la nación, así como a todos los estamentos de la sociedad española, sin perdonar a gobernantes ni autoridades. Esta actitud de análisis permanente y de severa censura apuntalada con criterios racionales y las teorías económicas más modernas, tendría por meta esencial la adopción de reformas constructivas capaces de acelerar el progreso de la nación y de aumentar la felicidad pública. Por otra parte, la Sociedad ideal haría las veces de un organismo administrativo local, encaminado a buscar remedios, mejoras o soluciones a problemas concretos y muy determinados de la comarca donde tendría su sede. Asumiria la redacción y el despacho de informes y expedientes, conservando siempre gran independencia de juicio, gran libertad de acción y de sugerencias, pero trabajando en constante armonía con los otros servicios del Estado.

Es obvio que estas dos tendencias van estrechamente mezcladas en la trayectoria de las Sociedades, con predominio momentáneo de una o de otra de ellas. Esta visión teórica —aunque exacta- no deja de ser algo borrosa todavía. Sólo después de estudiar detenidamente las distintas pretensiones o reclamaciones de las Sociedades y las mejoras que propugnan, veremos dibujarse nítidamente la fisonomía de la Sociedad ideal soñada por sus individuos.

so S. E. M., leg. 82/26, D. Felipe Marescalchi, Madrid, 31-VII-1786. 


\section{MEJORAS Y SOLUCIONES PROPUESTAS \\ POR LAS SOCIEDADES}

En su circular de 16 de julio de 1786, no se contentaba el Consejo con preguntar a las Sociedades si reconocían estar en decadencia y cuáles eran las causas de esta situación, sino que les pedía propusiesen «los medios que estimasen prudentes y efectivos para aficionar a las personas celosas y arraigadas a estos establecimientos tan útiles a la Monarquía), expresando "si para ello sería del caso la perpetuidad de los empleos de los Directores, con lo demás que se les ofreciere y pareciere conducente a la debida instrucción de este asuntom ${ }^{51}$.

A la pregunta sobre la perpetuidad del Director, que revela una visión muy estrecha de los graves y urgentes problemas que afligen a las Sociedades, éstas contestan de forma rapidísima (uno o dos renglones), sin concederle importancia. Esta solución ideada por el Consejo les parece un irrisorio remedio a todos los males que las aquejan y no suscita la menor discusión. La gran mayoría de las Sociedades (BAEZA - LEóN - MADRID - OSUNA - oviedo - puerto Real - SAN Clemente - SANTiago - Sevilla - soria - tudela - vera) prefieren que se elija al Director anualmente, con facultad de removerle, reelegirle y perpetuarle en caso de una persona excepcional, o particularmente benévola, estimando que no conviene hacer novedad en este punto, pues la perpetuidad suprimiría la emulación, cosa muy perjudicial. SAN CLEMENTE no entiende cómo la perpetuidad del Director puede influir en los adelantamientos de los Cuerpos Económicos. Soria, por su parte, opina que «el perpetuar el empleo de Director, que es el único aliciente que pudiera mover a los vecinos poderosos de este pueblo a alistarse por socios y trabajar en beneficio común, lejos de ser conducente para el logro de este objeto, les retraería sin duda de entrar en el número de Amigos del País y por lo mismo, será bien que así ésta como las demás Sociedades, continúen eligiendo o reeligiendo sus Directores anualmente».

Otras entidades que rechazan también la perpetuidad, inclinan hacia un empleo bienal (ZAMora) o trienal (BAZA - GRANAdA - LA BAÑeza - LUCE-

51 Véase pág. 
NA - LUgo - requena - SIgÜenza - Zaragoza) a fin de que todos los socios puedan aspirar a tan honroso título y se mantenga durante algún tiempo una misma línea de acción. JEREZ DE LA FRONTERA sugiere una elección por un tiempo indefinido hasta que la Junta decida cambiar. Cuenca desea que el empleo de Director no sea perpetuo, pero tampoco anual, cruDAD RODRIgo no tiene opinión y otras ni siquiera la formulan.

Las Sociedades partidarias de la perpetuidad del Director son: segovia (que desea extender la medida a todos los empleos), Medina DE Rioseco (que quiere así agradecer los desvelos de su fundador, D. Ignacio Núñez de Gaona, invistiéndole de este título vitalicio), GRAN CANARIA y LA GOMERA, muy satisfechas de los beneficios que reciben de su Director, el obispo D. Antonio de la Plaza, toledo que desea la perpetuidad, "pero no por elección general).

En resumidas cuentas, muy pocas Sociedades recogen la idea del Consejo y las que lo hacen, tocan este punto de paso y muy superficialmente. Está claro que para todas, la propuesta del Consejo «no era remedio» «ni venía al caso», como varias de ellas lo proclaman.

Tampoco se limitarán en sus sugerencias las Sociedades a exponer los medios de «interesar a las personas arraigadas y celosas». Saben mejor que nadie que la «tibieza) que se nota en los socios y el poco afecto que suscitan, proceden de causas múltiples ya expuestas en su repertorio de quejas. Desde el clima que rodea a las Sociedades hasta el mismo marco en que se mueven, todo necesita reforma. Los socios no perderán la oportunidad de proponer una serie de remedios para subsanar los defectos de que adolecen. Y una vez más, observamos tantas semejanzas entre las soluciones propuestas por entidades a veces muy distantes unas de otras que nos parece muy verosímil que hayan mantenido una activa correspondencia entre sí para intercambiar pareceres y opiniones antes de pronunciarse. E1 hecho es que todas presentan un frente unido.

La primera e indispensable reforma que se impone es la reducción del número exageradamente elevado de las Sociedades. El mejor medio es agrupar a las oscuras y débiles en torno a las matrices de provincias. Así opina Zaragoza: “Parece que sería conveniente reunir estos pequeños cuerpos y agregarlos a las Sociedades de las Capitales donde pueden subsistir, estableciendo en todos los corregimientos y ciudades subalternas, tres o más socios. Asi lo hace la Aragonesa que mantiene correspondencia con estas comisiones y ha acordado suministrarles el caudal necesario para los ensayos, tentativas y mejoramientos que propusieron... atendiendo con igual 
ardor y empeño los intereses del último y más infeliz pueblo de la misma manera que a los de la Capital donde reside la Sociedad».

Granada que aboga por el mismo sistema, tiene este bonito símili « Las pequeñas Sociedades son comparables a lagos que se hacen en las confluencias, pero luego se corrompen y secan. En cambio, la Sociedad buena es como el manantial que los renueva y corrobora. Esta subordinación dará más vida a los Cuerpos subdelegados y se evitarán perjuicios que ya se notan en tanta división de fuerzas y opiniones». Puntualizando aun más, SANTIAGo sugiere que se deje «una sola Sociedad por provincia, reduciendo las otras a meras Juntas patrióticas que fuesen como unas comisiones de aquélla». Gran Canaria aspira también a ser Sociedad matriz y tener supeditadas a su autoridad a las demás del archipiélago.

Si a nivel nacional, la multiplicación de Sociedades entraña un grave peligro para su eficacia y hasta su existencia, lo mismo se puede decir a nivel local del número exagerado de socios que viene a ser un gran estorbo para los Cuerpos. «Puede ser perjudicial, nota nuevamente Santiago, el excesivo número de vocales y que no asistan los mismos a dos juntas sucesivas. Hay que reducir a 20 ó 24 los socios de número, elegidos al principio del año y sometidos a la regla de asiduidad, o sea a la obligación de asistir a las dos terceras partes de las juntas que comprenderán además a los oficiales y antiguos Directoresm.

Inspirándose en el ejemplo de los claustros de catedráticos de las Universidades que opone a los (plenos», ZARAGoza comenta: "Sería conveniente que a las juntas semanales de los viernes, sólo tuviesen voto 24 individuos que debería nombrar la Junta general de los más antiguos y más frecuentes concurrentes, con el Director, Censor, Secretario, Contador y Tesorero, los cuales juntamente con los catedráticos de Matemáticas, Agricultura, Economía Civil, Filosofía moral, Derecho natural y de gentes, Secretarios de las tres Clases en ejercicio, deberian tener voto en todas las juntas, como los ex-Directores. Las Juntas generales sólo se convocarían para elecciones y para casos graves).

MADRID opina también que es imprescindible poner en adelante justos límites a la recepción de socios a quienes muchas veces ha sido preciso franquear la entrada con la única mira de que contribuyesen porque así ganaría la Sociedad la estimación pública y atraería a su seno a las personas más distinguidas del Estado.

Si quieren las Sociedades merecer el aprecio del Rey, tienen que erigirse con más miramientos que hasta ahora. Han do esperar con paciencia 
su creación "hasta que conste a la Superioridad que se ha 'reunido para formarlas el competente número de personas celosas, honradas e inteligentes» y después suplicar a los sujetos instruidos que concurran a ellas y desempeñen los principales empleos ${ }^{52}$.

Segovia es de parecer que el Consejo «debería fijar el número de vocales entre 24 y 60 . Si hay más que entren como supernumerarios, pasando luego a vocales. «Mientras sea lícito a cualquiera, siempre que se le antoje, assitir a las juntas y votar como el socio más antiguo y acreditado, será ridículo y despreciable el nombre de Amigos del País».

Partiendo de la constatación de que una numerosa concurrencia es embarazosa, ZARAgoza pide una selección rigurosa: “No se admita por socio indistintamente al que quiere alistarse. Que las propuestas se hagan por escrito y no se proceda a la admisión hasta la junta inmediata, la que deberá hacerse por votos secretos. Santiago preconiza también una vigilancia más estrecha en cuanto a admisión de socios y que esté firmada la solicitud.

En varios sitios, reclaman una disciplina para los Socios. Los movimientos de íngresos y de retiros son incesantes y demasiados cambios se producen en una misma Clase: "Soy testigo, dice D. Julián de Velasco, de la matritense, en el corto espacio de dos años que hace tengo el honor de ser su miembro, de haber visto renovada esta Clase de Oficios tres veces por casi todos, si exceptuamos un corto número de individuos). Tales trastornos originan una falta de principios con que dirigir los trabajos. Además, demasiada libertad conceden los estatutos al individuo de asistir o no. “A nadie, declara D. Julián de Velasco, se trata de forzar a entrar en el Cuerpo, pero si entra, entre con tales y tales obligaciones. No es esto coartar la libertad del individuo» ${ }^{53}$.

Para sujetar a los socios indolentes y pasivos, es necesario adscribirlos a una Clase, y esta condición debe imponerse de un modo drástico: “Hay que excluir del voto al que no está adscrito a una clase determinada, como hay muchos. También se debe prohibir la adscripción de ciertos individuos a varias clases» ${ }^{54}$. Dando un paso más, la Clase de Agricultura propone que

52 Elitista y timorata, la Sociedad toledana propone que «la superioridad dé idea a la Sociedad de la especie de personas que debe elegir con preferencia».

53 S. E. M., leg. $82 / 26$.

54 S. E. M., leg. $73 / 4$. 
el Cuerpo, adoptando nuevas medidas, "destierre» a los socios inactivos y - hecho notable - entre estas ovejas negras se encuentran muchas de aquellas "personas arraigadas» cuyo alistamiento recomendaba el Consejo: (Sería muy útil que estos Cuerpos se compusieran de personas arraigadas, si tuvieran las luces necesarias, pero la educación de las gentes acomodadas se descuida por lo común y estos Cuerpos necesitan para el despacho de los negocios, personas de instrucción» ${ }^{55}$. La misma severa opinión se encuentra bajo la pluma del Censor matritense: "Sería conveniente que las personas arraigadas se aficionasen a estos establecimientos. Pero la educación de los propietarios, de cualquier clase que sea, no permite aún que se fíe exclusivamente de sus lucesi esta revolución... [Es mejor que en esto actúe] la Sociedad compuesta por personas de todas carreras, estados y condiciones». Es verdad que ciertos socios hablaban con gran franqueza y «con aquella libertad que debe reinar en todo país donde ha establecido su imperio la filosofía». Libertad y filosofía que bien pudieran inspirar alguna inquietud al Consejo de Castilla.

El fin de las medidas que acabamos de exponer es evidente; reducir el número de Sociedades y Socios en beneficio de la calidad y eficacia de los mismos. Y esta calidad, las sociedades piensan buscarla en dos direcciones: calidad social y calidad humana o cultural.

El señor Aseargorta [MADRID] piensa, a pesar del concepto poco ventajoso de su consocio sobre las personas arraigadas, que éstas serían una aportación de peso al Cuerpo. "Siendo los de más arraigo los que constituyen la primera nobleza del Reino, se deberá procurar con todo esfuerzo aficionarlos con preferencia a las Sociedades. En efecto, esas personas tienen un influjo poderoso y suelen ser benéficas, generosas y afables. Las adornan las circunstancias más idóneas para concurrir al bien general por medios sólidos. "Pero reconoce el autor del dictamen que esa clase llena de honores y abundante en bienes de fortuna, necesita particulares estímulos para concurrir a las Juntas. Y el único que descubre, el más propio para almas nobles, es la confianza que se depositaría en ellos, dándoles un sitio preeminente en aquellas Corporaciones. Apóstol del pragmatismo más que de la igualdad de los hombres, el Señor Ascargorta propone pues «establecer que en todas las Sociedades del Reyno, el Director fuese un Grande, substituido por otra persona condecorada donde no residiese un individuo de esta clase. Esto aumentaría, dice, la representación de dichos Cuerpos y 
les traería otras ventajas. Para representar a las Sociedades en Corte y Tribunales donde tuviesen expedientes, sería bien que autorizasen siempre a un individuo de la primera nobleza, sin perjuicio de que tuviesen éstos a su orden los subalternos necesarios para las diligencias en que no fuese necesaria su persona) ${ }^{56}$.

La sugerencia de LUGo es muy parecida y parte de los mismos motivos: «El Reverendo Obispo debería ser Director nato, con otro subalterno nombrado por la Sociedad para presidir efectivamente las juntas»). AlaEjos, que en sus Constituciones, propuso por Directores los Alcaldes ordinarios, se declara encantada con esta (medida acertada), pero señala la necesidad de crear el oficio de Vice Director, para ejecutar las decisiones de la Sociedad, (por: si no lo hacen los Directores).

Son numerosas las propuestas presentadas al Consejo, algunas de ellas sólo válidas para las Sociedades más importantes. Madrid desea que cada Clase tenga un Censor, porque el Censor único de la Sociedad está abrumado de tareas y sólo la fatiga que causaría el despacho de todo lo respectivo a cada Clase vencería las fuerzas corporales de cualquiera. Así, quedan pendientes los asuntos o se arrinconan largos meses sin solución, frenando Ia marcha de la Sociedad y entibiando el ardor de los socios. También opina que convendría que cada Clase tuviese un Presidente fijo, por ser poco favorable a los progresos de ella la costumbre actual de presidir el más antiguo de los asistentes. La Clase, con este sistema, es un cuerpo sin cabeza. La duración ideal de aquel cargo de Presidente de Clase sería de tres años, plazo que da bastante intervalo para fundar proyectos y verlos concluídos's ${ }^{57}$.

Oviedo hace una sugerencia original: propone la creación de otros oficiales llamados Promotores que tendrían por misión estudiar la constitución y estado del país (población, agricultura y variedad de cosechas, industrias y artefactos, oficios, pesca, comercio interno, navegación, diversidad de pesos y medidas, etc.....) con obligación de señalar los puntos dignos de reforma. Tendrían asimismo que denunciar las causas de los abusos (leyes, privilegios, intereses creados, costumbres, corruptelas) para solicitar la providencia general o particular necesaria. Cada promotor ostentaría el título de benemérito, se le concedería alguna dotación, un amanuense y cierta cantidad en concepto de gastos de viaje.

\footnotetext{
56 S. E. M., leg. 73/4.

57 S. E. M., leg. 73 bis $/ 35$.
} 
Unas cuantas medidas propuestas atañen a la disciplina del Cuerpo. Por ejemplo, «que el Consejo permita que el Director imponga alguna pena a los que no justifiquen sus faltas o a los que quieren prevalezca su opinión», pide MEDINA DE RIOSECo. "Que se establezca la obligación de asistir a juntas para los oficiales, estando en la ciudad; si no pueden, que envien una esquela. Y que en vez de semanales sean las juntas ordinarias mensuales o quincenales», reclama oviedo. Santiago quiere que se premie la asiduidad y que no pueda ser reelegido quien no asistió a las dos terceras partes de las juntas y eso en todos los empleos, “quedando entendido que la Sociedad propondrá medidas para hacer apetecibles los oficios».

Tantas sugerencias encaminadas a crear nuevos puestos para aliviar la labor de los que están en funciones y flexibilizar la marcha de la corporación, supone una revisión de los estatutos vigentes cuyas imperfecciones subrayan los informes en no pocas ocasiones. Una reforma de las estructuras internas que robustezca la constitución de las Sociedades y ponga las Clases y los individuos en acción, se impone, pues, con urgencia.

Es preciso también desarrollar el espíritu patriótico y los conocimientos económicos que constituyen la razón de ser y los fundamentos de aquellos Cuerpos. ¿Cómo llegar a este resultado apetecible? Por medio de la enseñanza de todo un plantel de jóvenes que serán el día de mañana los socios y patricios ideales. Las Sociedades son por definición unas escuelas permanentes de patriotismo y deben pues admitir alumnos. VALLADolid defiende esta teoría en la que ve una novedad muy beneficiosa: «En estas concurrencias, estos jóvenes habilitarían sus talentos y nutridos desde la tierna edad con el amor al bien público, serian en todo tiempo buenos ciudadanos, aprenderían bellas máximas y no vivirían entregados al ocio y fanatismo a que, o su pobreza o su abundancia, regularmente los inclina. Acreditarían sus méritos en los estudios del amor público, como en cualquier otro estudio». D. Juan Bautista de San Martín, de la matritense, desarrolla con complacencia la misma idea: «El hombre quiere ser enseñado a ser útil como bueno... Si queremos hacer el bien a la nación, poblar y perpetuar estos establecimientos, si queremos inmortalizar nuestras ideas, recibamos alumnos, criemos sucesores, traigamos a quien trasladar nuestros designios... No hay otro medio más seguro de llenar las Sociedades de hombres útiles, ni de aficionarlos a estos Cuerpos» ${ }^{58}$. Y recuerda que la Sociedad de Dublín, la primera en adoptar este principio, ha sacado ya frutos copiosos 
de este medio. Varias Sociedades de provincias preconizan la misma solución. Después de afirmar que hace falta «imprimir y fijar en los ánimos de todos los individuos de la ciudad los nobles ideales de amor a la patria, caridad y beneficencia», opina sevilla que "para difundir los ideales de la Sociedad, convendría establecer un Seminario de Nobles en las capitales de provincia para enseñanza de la Filosofía moral, como se hace ya en las Universidades).

La idea tiene más adeptos. Zaragoza también la expresa con vigor: “Para desterrar la ignorancia y arrancar de raiz las preocupaciones vulgares, conviene dar a la juventud acomodada una educación esmerada en Seminarios Patrióticos... para que, imbuidos los jóvenes en las máximas del patriotismo, se críen estos viveros que después produzcan la abundancia del reino». Continúa diciendo que si el Rey se digna hacerla beneficiar de la misma liberalidad que a la SOciEDAD BASCONGADA, tendrá lo suficiente para la dotación de las escuelas del Seminario que tiene proyectado. Si la creación de un Seminario parece desproporcionada a los recursos de una Sociedad menos pujante que la Aragonesa, existen soluciones de sustitución: "Que mande S. M. que en todas las casas de estudios religiosos, si pudiera ser, mantengan una cátedra de Economía, para enseñar a la juventud a huir de los peligros de la ociosidad... Que se creen en los Seminarios Conciliares unas cátedras de Economía política y otra de Agricultura), propone segovia. Si las casas religiosas no pudiesen costearlas, tendrían que hacerlo las Sociedades Económicas, para formar futuros socios. Toda Sociedad debería aplicar sus pensamientos y fondos en criar tales pobladores).

Segovia que trae entre dientes a su Corregidor, quiere que se establezca en las Universidades y Seminarios Conciliares unas cátedras de Economía Política, de Comercio y Economía rústica, que estén obligados los futuros Corregidores y Jueces a presentar certificación de haber asistido a un curso completo de las aludidas cátedras y que se considere en adelante esta formación como requisito indispensable para el logro de aquellos cargos. Porque, prosigue insistiendo, la falta de cooperación de los Corregidores procede muchas veces de la ignorancia. Además, en el Real Decreto de 29 de marzo de 1783 en el que se estipula (artículo 6..$^{\circ}$ qué circunstancias deben concurrir en los que aspiran a empleos de Corregidores o Alcaldes mayores, se les recomienda fomentar las obras en beneficio de la Agricultura y Educación de jóvenes, dos aspectos de la actividad genuina de las Sociedades. Es de su obligación, pues, favorecerlas, so pena de castigo. Y termina segovia expresando el deseo de que los informes qué redac- 
ten sobre las Sociedades no sean secretos, sino que se comuniquen a las entidades interesadas.

Por su parte, gran CaNaria y oviedo piden la adopción de dos medidas importantes que conciernen a las relaciones de las Sociedades con el Gobierno. Aquélla solicita «la merced de poder dirigirse al Consejo, excusando los trámites ordinarios de informes a través de la Audiencia, que resultan larguísimos y onerosos y a veces contraproducentes». La providencia que propone oviedo no es de carácter personal y de haber sido aceptada, agradara probablemente a muchas Sociedades. Quiere «que haya en la Corte un agente general de todas las Sociedades por el cual transitarian todas las representaciones y gestiones y que avisaría a todas las Sociedades de las medidas generales. Así, concluye, irían perdiendo parte de su inacción actual». Ya TUdELA vislumbraba esta necesidad de unificación de los programas de los Cuerpos Económicos, cuando sugeria que cada Sociedad presentase el plan de sus ocupaciones al Ministerio de Estado para aprobación y unión de sus proyectos.

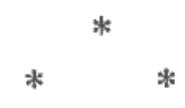

A las Sociedades, les sobra patriotismo, les sobra buena voluntad, les sobra abnegación, pero hay algo de que carecen en sumo grado: el dinero. Monótonamente, el legajo compacto del A.H.N. que estudiamos y los documentos del archivo de la Matritense que lo complementan, repiten la sempiterna cantinela de enecesitamos dotación, no tenemos medios, faltan los fondos». Ya sabemos que en la mayoría de los casos, no tienen más recursos que la contribución de los socios, es decir, poquísimo, respecto de las muchas empresas que quisieran acometer: «Para desempeñar su instituto, dice LA mAtritense, tiene que asumir gastos considerables; se halla pues en la dura alternativa o de abandonar sus tareas o de contar con una competente dotación de que en el día carece, aunque la pidió por una represen. tación». Entre los (medios prudentes y efectivos» que prevé para aumentar la productividad de las Sociedades, D. Manuel Sixto Espinosa pone en primer lugar (dotar la Sociedad». En un dictamen que contiene una serie de considerandos muy discutibles - ya que se aplica a demostrar la opulencia de España en aquellos años y a defender las Sociedades de las críticas que suscitan asegurando que no ha empeorado la situnción económica desde que se crearon-, D. Phelipe Marescalchi estima que le incumbe al Gobierno hallar los medios de restaurar las Sociedades decadentes y que to más urgente es darles fondos y autoridad. También clama sEgovia que las 
Sociedades necesitan una dotación fija y decente. Para paliar la falta de fondos, admiten el mayor número de socios, pero, observa «es imposible que con nuestra educación, se encuentren sujetos que sacrifiquen sus intereses sólo con el fin de adelantar el bien común». Por lo tanto, «si la Superioridad reconoce que las Sociedades son útiles y ventajosas, tiene que proporcionarles los fondos necesarios, por ejemplo, un dos por ciento de los Propios del Reino». Remacha el clavo D. Manuel Sixto Espinosa subrayando la necesidad de una «dotación competente para dar a la Sociedad más dignidad y decoro». Los individuos de LA matritense, dice, han hecho hasta ahora espontáneo sacrificio de su tiempo, luces y caudales en beneficio de la patria, sin otra mira de interés particular, pero esto no puede seguir así y tampoco basta.

No se limitan las Sociedades a reclamar una dotación. Acostumbradas a las reglas y lentitudes administrativas, suelen señalar para acelerar el proceso de atribución, de qué caudales se pueden sacar «sin perjuicio de tercero", fórmula que se repite varias veces, las crecidas cantidades que necesitan. Hemos visto ya que sigüenza indicaba al Consejo tres cajas donde (estaba parado» el dinero (el fondo de vacantes de la mitra, la caja de impuestos locales de Guadalajara y el fondo pío beneficial). Jerez DE LA FRontera defiende la misma tesis: «Si mandase S. M. aumentar sus fondos de los caudales de los Propios o Arbitrios de los pueblos donde están establecidas las Sociedades", se quedarian satisfechas, a to cual asienten LEón y otras corporaciones que piden que se les asigne algún fondo de Propios o de beneficios. Medina de rioseco solicita mil ducados ${ }^{59}$ en cada vacante del obispado de Palencia para aliviar la miseria de muchas familias. Osuna quisiera podert aprovecharse de los réditos de ciertas dehesas y de las rentas de unos Patronatos y obras pías por conmutación solicitada de sus respectivos patronos. Cuenca sugiere arbitrios que no redunden en detrimento del público, como son los Expolios o el Fondo Pío beneficial, «que no son cosas nuevas». También podría apropiarse las condenaciones de cortes de montes que se destinan normalmente a los Propios para aumento de plantíos. Lucena, ni corta ni perezosa, hace muchas sugerencias: tomar los depósitos de los pequeños censos eclesiásticos seculares y con ellos fundar un Montepío de préstamos; beneficiarse del derecho de Almojarifazgo ${ }^{60}$; suprimir varias cofradías gravosas al público y recuperar sus fondos, pero con la obligación de respetar los compromisos de su fundación.

59 El ducado era una moneda imaginaria equivalente a 11 reales de vellón.

60 Almojarifazgo: derecha que se pagaba por los géneros o mercaderías que salían del 
Todas las Sociedades buscan soluciones asequibles y nada onerosas para el vecindario y sus peticiones son casi iguales. Sin embargo no hay absoluta unanimidad entre los socios. Unos no están conformes con la solicitud de dotación: “Sin fundación, escribe la Clase de Agricultura de madrid, será menor la suma de bien que pueden hacer las Sociedades, pero será más cierto y durable que el [bien] que se pueda hacer con la dotación, que la pondría en una dependencia muy peligrosa y funesta” ${ }^{61}$. Especie que el Censor, en su sintesis general, recoge a su vez: "La Clase de Agricultura piensa que la dotación hará perder a la Sociedad la libertad de exponer su dictamen». Tudela preconiza otras soluciones dignas de interés: "Que no se admita memorial alguno sin que el pretendiente tenga la calidad de socio; así crecerán las suscripciones y los caudales de la Sociedad». El arbitrio, por cierto, más eficaz, sería, dice, dotar a cada una de las 44 Sociedades existentes con mil pesos fuertes ${ }^{62}$ de renta anual. El Rey pondría el capital correspondiente en el Banco Nacional o sea 270.733 pesos fuertes y 10 reales vellón, siendo el rédito regular de $16,25 \%$. Le tocaría a cada Sociedad 6.153 pesos fuertes 33 maravedíes navarros de capital. Podría entonces destinar 500 pesos de réditos para fondos y gastos y con los otros 500 cubrir aquel empréstito. En el espacio de doce años, quedaría el Rey pagado no sólo del capital suplido a las Sociedades, sino que cobraría una ganancia efectiva de 6.387 pesos y medio fuertes por las acciones impuestas con él en el Banco, lo que equivale a una renta de 11,5\%. Así disfrutaría cada Sociedad año tras año de una gruesa dotación de 1.000 pesos anuales y se podrían rebajar las contribuciones de los socios en 50 reales de vellón.

Es evidente que tal propuesta no carecía de atractivo y tal vez hubiera sido, además de fácil, una solución hábil. Pero la distribución de aquel dinero prestado por el Rey no podía efectuarse igualmente entre las 44 Sociedades. Hubiera recaído la inversión en un número determinado de Sociedades matrices que dispondrían de una cantidad global para su uso y el de las juntas subalternas establecidas en el territorio de su jurisdicción. Tal restricción tenía además la ventaja de rebajar la importancia de los caudales adelantados. En realidad, nada parecido se produjo y los argumentos y los cálculos de la socicdad tudelana se perdieron en la niebla. Cada

reino, por los que se introducían en él o por aquellos con que se comerciaba de un puerto a otro de España. (Dicc. Acad.).

61 S. E. M., leg. $82 / 26$.

62 Peso fuerte: equivale a peso duro, moneda de plata de peso de una onza y que valia 8 reales fuertes o veinte de vellón. (Dicc. Acad.). 
Sociedad, grande o pequeña, se vio reducida a buscar desesperadamente en su propio terreno los arbitrios necesarios a su supervivencia.

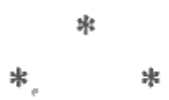

Frente al pueblo que sólo manifiesta incomprensión y animadversión hacia las Sociedades, ¿de qué medios disponen éstas para conseguir que muden de opinión? Como lo dice D. Bernardo Hidalgo, «es necesario presentarlas al público bajo un aspecto de mayor dignidad y decoro ${ }^{63}$. Para animar a las Sociedades decadentes o claudicantes, hay que estimularlas con el honor y la utilidad.

«No bastan meros oficios de atención o buenas palabras. El poco o ningún aprecio causa desaliento», advierte la Clase de Agricultura de Madrid. VAlladolid emite este juicio perentorio y profético: «Si la indignación del Rey fuese efectiva contra estas racionales polillas que corroen mordaz y eficazmente el estambre de las Sociedades y si por otra parte fuese efectiva también' su afección a estos Cuerpos... puede esperarse que continuarán los favorables efectos que producían las Sociedades... De lo contrario, serán infructuosos todos los discursos que se hagan para conseguir este fin». "Que el vulgo vea que estos establecimientos son el objeto de la protección del Soberano y de sus Tribunales... Así desterrará [el Rey] las murmuraciones perniciosas que influyen en el atraso que puede haberse notado en algunos y en todos disminuyen sus fondos y el número de contribuyentes» recalca zaragoza. De modo que, "si el Gobierno se resuelve a sacar de estos Cuerpos todo el fruto que pueden producir, deben ser un objeto muy distinguido de su protección... Los Fiscales, Audiencias y Chancillerías, Presidentes y Regentes, Intendentes y Subdelegados, Ayuntamientos, Juntas provinciales de Comercio, Consejos y Tribunales deben pedir y oír los informes de estos Cuerpos y aprovecharse de sus luces y auxilios... y entonces se verá como trabajan a porfía para la común utilidad en desempeño de esta confianza que les será muy lisonjera» ${ }^{64}$.

Esta alusión a la satisfacción dada al pundonor no es casual, como se ve por estas palabras de D. Manuel Sixto Espinosa [MAdrid]: “Convendrá que se tenga noticia de las resoluciones, pues es claro que los socios que

63 S. E. M., leg. 82/26.

64 S. E. M., leg. $79 / 10$. 
dan los dictámenes se complacen en ver que la Superioridad hace caso de ellos, así como se ontibian cuando experimentan lo contrario, porque al fin es carácter esencialísimo del celo enojarse por el menosprecio de los avisos que sugiere) ${ }^{65}$. Gran canaria opina que el Consejo debe fiarse de las medidas que le propone, porque no son frívolas, sino maduramente meditadas y útiles. Por ejemplo, en orden a conservación de montes y denegación de datas en su término, «es mejor dejar la decisión a los naturales que tienen conocimiento práctico, que a unos sujetos que, aunque posean la jurisprudencia en sumo grado... no dejan de ser forasteros y por consiguiente no es regular que excedan a los naturales en el conocimiento propion. LA MATRITENSE insta al Consejo a que recuerde a todas las autoridades de la nación, que deben trabajar en estrecha colaboración con los Cuerpos Patrióticos, condición esencial para pretender hacer progresos notables y rápidos. Agradece al Tribunal la confianza que deposita en ella solicitando constantemente su dictamen. Los demás Consejos, Tribunales y Magistrados han de imitar su ejemplo. Tudela propone que los Ayuntamientos ayuden con su autoridad y fondos so pena de incurrir en el desagrado del Rey. La misma actitud de cooperación se puede exigir del clero y de los prelados, dice SEgovia: "Que los obispos expidan circulares a los párrocos para que coadyuven a los pensamientos y proyectos de la Sociedad, publicando la obligación que todos tenemos como cristianos de contribuir al bien común».

La Real protección podrá revestir otras formas también apreciables. Las Sociedades se encuentran a menudo desamparadas ante la enorme y asmática máquina administrativa del Estado. La lentitud en el despacho de los negocios es otra causa de desmayo de los socios que ven los asuntos y representaciones de su Cuerpo retardados considerablemente. LA ARAGonesa da unos diez ejemplos de instancias suyas que no han recibido contestación: "Eso, agrega, entibia a los socios celosos y causa a las Sociedades gastos de agentes... Deben sus expedientes ser preferidos como que se promueven sin otro interés que el beneficio de todos». Por eso, «sería oportuno se diese pronto curso a sus negocios, pidiendo al Sr. Gobernador del Consejo una lista de los mismos al escribano de Gobierno... que se las pasaría semanalmente».

Varias son las Sociedades que se quejan de los estorbos y dilaciones administrativas, viendo en ello una causa esencial de decadencia: «Es de suma importancia la brevedad en el despacho de los negocios que la Sociedad promueve por sí misma, en suposición de que cualquicr retraso embaraza el ejercicio de sus facultades, como lo tiene bien probado esta Clase de Artes y Oficios en la imposibilidarl de mejorar la constitución 
gremial, mejora que había ya conseguido con las protecturías de los oficios, si el Consejo hubiera aprobado alguna de tantas ordenanzas como hasta ahora se le han dirigido', protesta el socio de la matritense D. Manuel Sixto Espinosa ${ }^{65}$.

Serena y práctica como siempre, LA BASCONGADA examina detenidamente la cuestión. ¿Cómo reducir las dilaciones en el despacho de los asuntos de las Sociedades? «Nombrando una junta o alguna sala de los Tribunales ya establecidos, que tuviese por especial y privativo encargo el cuidado de recibir las consultas, representaciones y propuestas de todas las Sociedades, pasarlas con un informe a manos del Rey por la Secretaría que se le asignase, recoger las resoluciones de ellas y encaminarlas a los Cuerpos... Esta providencia daría grande actividad y movimiento a las empresas de las Sociedades y contribuiría a mantener su fervor al celo de sus individuos. Además, sería el centro común para comunicarse las noticias y hacer combinación de ideas, proyectos y solicitudes) ${ }^{66}$. Muy semejante es la propuesta que hace santiago: "Que el Consejo destine un día de cada semana para zanjar los asuntos de las Sociedades»; añadiendo otra no menos útil: "Que los oficiales municipales o reales faciliten todos los datos que necesitan las Sociedades, las que abonarían, como es lógico, los gastos de investigación y traslado».

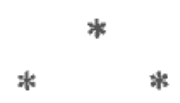

El corolario de estas medidas encaminadas a devolver a las Sociedades dignidad y decoro, es que la pertenencia activa a los Cuerpos Patrióticos que cooperan con desinterés y constancia a la labor nacional, debe constituir un mérito oficialmente reconocido. "El título de socio debería requerirse indispensablemente para el logro de todos aquellos cargos que deben recaer en personas hacendadas como son los regidores). Las Sociedades remitirian a fin de año a las Secretarías de las dos Cámaras y del Estado una lista alfabética de sus individuos con expresión de su asistencia a las juntas y de lo que hubieran trabajado en ellas. Estos servicios figurarian en las relaciones de méritos de todos los pretendientes, lo mismo eclesiásticos que civiles y para los oficiales de regimientos provinciales. Así resultaría fácil estimular a los miembros de Comunidades o Cuerpos poderosos a que se alisten en las Sociedades que antes trataban de desacreditar. 
Los Cuerpos Patrióticos esperan otros beneficios más de este alto patrocinio, no teóricos y lejanos, sino concretos y que deben aplicarse a todas las Sociedades constituídas sin excepción. Zaragoza ruega que «se digne S. M. expedir un Real Decreto o Cédula ratificando las promesas antecedentes, declarando que... le han sido agradables las fatigas de los socios aplicados" y que, en prueba de ello, concederá ventajas a los socios beneméritos. ¿Qué clase de ventajas? Unas conciernen a las Sociedades, otras a los individuos. "Reconociéndolas oficialmente», dice con buen sentido la SOCIEDAD TUDELANA que desarrolla de modo más explícito su pensamiento: "Que aquel honor y aprecio que se merecen semejantes Cuerpos, mirándolos como unas ilustres escuelas de esta gran ciencia [la Economía] y del Patriotismo... y que se les dé voto en las Cortes generales de este Reino» [de Navarra].

Elevadas así a nivel de organismos de Estado, tendrán que lucir un distintivo. "Sería conveniente, opina Lugo, distinguir a las Sociedades con alguna real divisa, privilegios, uniformes o fuero personal, puesto que sacrifican su caudal en beneficio público. Sería el aliciente más poderoso». Oviedo es de parecer que podría excitarse el celo de los socios por medio de cun uniforme modesto y decente de paño del reino y una divisa con su empresa que fuese señal de alguna distinción que los seglares pudiesen traer en el ojal de la casaca y los eclesiásticos como las insignias de Ordenes militares». Ciertos socios optarían por un uniforme «como la Santa Hermandad de Ciudad Real, de Toledo o la Real sociedad bascongada» o, en su defecto, por una medalla de plata al pecho ${ }^{67}$.

Por regla general, los informes se extienden poco sobre las ventajas que podría otorgar el Rey a las Sociedades consideradas como entidades. En cambio, pormenorizan prolijamente toda clase de sugerencias en favor de los socios. "Será muy justo que premie S. M. a los que se esmeren en beneficio público y prosperidad de sus vasallos», aconseja LEóN. Los individuos abnegados y asiduos se creen, con todo derecho, acreedores a una digna y debida remuneración. Claro que «las personas verdaderamente celosas no necesitan este estímulo, nota Manuel Sixto Espinosa [MADrid], pero el estímulo es también necesario para hacer celosos y aficionados». Su

67 A partir de 1800 , las Damas de la Matritense que llevaban más de tres años de afiliación fueron autorizadas, al igual que sus colegas masculinos, a llevar una medalla ovalada de plata, colgada de una cinta verde por los lados y blanca por el ceatro. El acuerdo correspondiente se tomó en la Junta de I0 de fcbrero de 1800. 
consocio Manuel Ambrona piensa a su vez que los premios y las distincionea son necesarios para atraer a unos e inclinar a otros. La Clase de Artes y Oficios se muestra aún más explícita: "Para estimular poderosamente el ardor al trabajo, es preciso crear una nueva clase de socios con el título de Beneméritos, capaz de producir el efecto que se desea. Proporcionaría a sus poseedores ciertas prerrogativas como la exención de contribuir, la de obtener exclusivamente oficios o empleos de la Sociedad, la de presidir juntas de comisión, porque, reprocha D. Agustín de la Cana [Madrid], "hoy un título de socio no distingue al laborioso del poco aplicado» ${ }^{68}$. Un compañero suyo expresa la misma opinión: "Conviene despachar un título de socio distinguido y sobresaliente que incluya cierta laudatoria». Se dispensaría, claro está, con suma parsimonia o después de un número determinado de años de asistencia o desempeño de comisiones o informes particularmente importantes o arduos. Oviedo inclina también a crear una nueva categoría de socio benemérito de la que saldría el Promotor.

Para alentar a los sujetos a que se alisten, dice D. Agustín de la Cana, y recompensar a los más eminentes, se podrían acuñar tres medallas de oro con el Real Busto que llevarían en el reverso especificación de las tres clases. Otro medio sería hacer presente al Rey anualmente, para que les diese su beneplácito, los nombres de los individuos más activos. SANTIAgo quisiera que se atribuyesen dos condecoraciones a los Directores con más de seis años de ejercicio, y se concediesen honores del Consejo y honores de Chancillerías o Audiencias a los demás oficiales. Las palmas solicita «alguna merced, real cédula de preeminencia, gracia de hábito de las Ordenes militares o pensión sobre encomiendas para los que más se han dedicado a las Sociedades, porque no siempre basta la agradable satisfacción y honor de servir a la Patria». Unas corporaciones sugieren que el Rey conceda a los oficiales más distinguidos algunas cruces de Carlos III, con pensión o sin ella. Alguna hay que preferiría que las pensiones correspondientes se reservasen para la Sociedad, como dotación. Lo más sencillo tal vez, opina el socio Ascargorta, sería que se señalasen a las Sociedades cierto número de cruces pensionadas de Carlos III y supernumerarias, para que ellas mismas propusieran a sus vacantes los socios adornados de las particulares circunstancias que exigen. Lo mismo se haría con las Ordenes militares que, si bien fueron en su principio Cuerpos militares y religiosos, no conservan ya su carácter primitivo. No habria pues inconveniente,

ts. S. E. M., leg. 82/26, parecer de D. Agustín de la Cana, Madrid, 31 de julio de 1786 . 
explica, en destinar una tercera o cuarta parte de las encomiendas de cada orden militar y otra semejante porción de hábitos. En fin, "para los que no pudiesen recibir algunas de las gracias expresadas, hay honores con sueldos y medios sueldos de Ministros de Tribunales del reino, de Secretarios de S. M., de Contadores y Tesoreros del ejército y otras mercedes de que una persona más versada pudiera en caso necesario formar catálogo" ${ }^{69}$.

Las condecoraciones y mercedes satisfacen, por cierto, el pundonor. Pero otras ventajas más concretas se pueden buscar para los socios distinguidos. Por ejemplo, que los méritos adquiridos en el seno de las Sociedades libren a las personas de carácter de otros servicios públicos que deben a la comunidad en que les ha tocado vivir. Tal propuesta la hacen sobre todo unas Sociedades modestas: “Como aliciente para los socios, las personas hacendadas y de capacidad, escribe el Director de LA gomera, D. Miguel de Echevaría, creemos convendría que se les dispensase alguna gracia particular, exceptuándolas en las pensiones concejiles de los pueblos, o si quieren plantificar telares de tejidos, tenerías para curtidos u otras, que se les conceda franquicia especial para su introducción, extracción y comercio». Es poco probable que LA GoMERA se haya confabulado con MEDINA DE RIoSECo. Sin embargo, dicen exactamente lo mismo: «Que a los oficiales se les podría libertar de los cargos penosos concejiles y vecinales, como de los honorificos»).

Otras ventajas positivas piensan conseguir las Sociedades de la benevolencia del Rey. Desean que los servicios prestados como oficiales, comisionados o agentes, se tomen en consideración y figuren en las relaciones de méritos de los pretendientes a cargos de la administración, de la milicia o de la iglesia. En este particular, coinciden casi todas las Sociedades. Zaragoza espera, como ya hemos dicho, que el Rey ratifique las promesas hechas anteriormente y declare... "que en prueba de su Real aceptación, sean desde luego preferidos en iguales circunstancias para todos los empleos, magistraturas, oficios seculares de la República de cualquiera clase y carrera que sean, y para todas las dignidades eclesiásticas, haciéndose presente a S. M. este mérito por las respectivas secretarias del Despacho universal, sin excepción alguna. Los certificados serán extendidos con arreglo a to que conste de los libros») todo lo cual, subrayan los redactores, es muy conforme al espíritu de la Real Cédula expedida sobre el modo de proveer las varas y corregimientos y de graduar la valía de los pretendientes.

69 S. E. M., leg. $73 / 4$. 
Tudela adopta la misma postura y quiere que las listas de obras y memorias con los nombres de sus autores se formen y publiquen cada año en la Gaceta y se tengan en cuenta para el logro de las pretensiones». ZaraGOZA formula claramente su modo de pensar: «Las personas arraigadas... aspiraron siempre con el mayor empeño a la obtención de los empleos políticos... Si se dignase mandar que no se consultasen para todos estos oficios sujetos que no sean socios... prefiriéndose a los más dignos... se lograría atraer a casi todas las personas arraigadas del reino, trabajarian a porfía, desempeñarian puntualmente las comisiones y proporcionarían a las Sociedades un caudal suficiente para realizar todos los proyectos sin gravar al Erario...» Granıdd desarrolla la misma tesis: “Entre los méritos para obtener un empleo público, debe figurar el haber pertenecido a una Sociedad Económica donde el pretendiente, llenándose de ideas imparciales o benéficas, se acostumbre a la suavidad, discreción y fidelidad con que debe promover a favor del común servicio del Soberano y del Estado... Será equitativo establecer por ley indispensable que en todo memorial o pretensión... se atienda con particular preferencia el que vaya acompañado de la certificación de ser el interesado, individuo de una Sociedad Económica en la que conste haber cumplido con todas las obligaciones del instituto». Se hará la certificación a partir de las actas de manera que el socio trate de que su nombre figure en los libros de sesiones, desempeñando alguna comisión o servicio particular. "Así, concluye Granada, se despertará la indolencia». D. Manuel Sixto Espinosa [MADrid] propone como medio más eficaz para destruir la perniciosísima preocupación de que son víctimas las Sociedades «que en la elección de los sujetos para las magistraturas y otras dignidades y altos empleos del Estado, el simple título de socio no se tuviese por un indefectible mérito, pero su falta se considerase como un cierto desmérito" ${ }^{70}$

VAlladolin se muestra aun más intransigente. Quiere que la calidad de socio sea una condición imprescindible para pretender algún cargo: "Que positivamente se excluyan de los empleos y gracias reales a los que no sean miembros de alguna Sociedad». Sevilla subraya un punto ya senalado por otros Cuerpos, a saber que las Sociedades son una escuela inmejorable de formación para ciertas carreras administrativas: "Que se tengan en cuenta para colocación o ascensos, los méritos contraídos en el seno de las Sociedades», con tal que los socios hayan demostrado cierto celo y presenciado más de la mitad de las sesiones y desempeñado varias comisiones.

70 S. E. M., leg. $82 / 48$. 
Para proveer empleos de Regidores, Veinticuatros, Corregidores, ya fuesen de capa y espada, ya de letras, que se imponga como condición haber frecuentado por lo menos dos años las Juntas de una Sociedad Económica para ser capaz de poner en práctica los mismos objetos de beneficio y utilidad pública que son el atributo de las Sociedades. Así se evitarán roces y disgustos. Idénticas aptitudes se exigirían de los pretendientes clérigos: "Conviene hacer entender que la calidad de socio en la respectiva provincia se mirará como un requisito esencial en toda persona decente, eclesiástica o seglar, que aspire a obtener prebendas, dignidad o empleo, dide vera. Ascargorta piensa que se puede aplicar el sistema a otras carreras, como por ejemplo las Intendencias, ya que los conocimientos que se adquieren dentro de las Sociedades constituyen buena parte de dicha especialización.

Con la imposición de aquellas nuevas normas, se modificaría radicalmente el clima general, ganarían prestigio las Sociedades y se establecerían unos vínculos estrechos a todos los niveles administrativos, lo que facilitaría y aceleraría las tareas de los Cuerpos Patrióticos. Así todos los engranajes de la máquina del Estado participarian en la gran obra de restauración de la economía nacional. La regeneración del país sería la obra y la meta de todos.

Con estas últimas sugerencias, concluye el pliego de reivindicaciones de las Sociedades. Libremente, han expuesto sus justas y sesudas pretensiones, revelando una uniformidad de pensamientos, miras y soluciones verdaderamente notable. De esta larga sarta de quejas, reconvenciones, protestas, denuncias y reflexiones a menudo ácidas, se desprende con toda nitidez un pensamiento unánime y dominante: para asegurar progresos generales y rápidos, las Sociedades necesitan protección, confianza, fondos y recompensas. Si se quiere pues que lleguen a un estado floreciente, es indispensable dar oídos a sus explicaciones y críticas y condescender a sus sugerencias y deseos. Es cuestión para ellas de vida o muerte. El aire que las rodea se hace a veces irrespirable y muchas yacen aletargadas. Mil obstáculos y asechanzas entorpecen cuando no detienen su marcha. Gran parte del celo patriótico se ha extinguido ya. Los buenos patricios están desalentados, des. engañados de buenas palabras que no llevan a ninguna parte y desertan de sus filas. Se han desvanecido las ilusiones de premios y colocaciones que se habían dejado entrever. 
Necesitan ante todo las Sociedades un apoyo moral, sentirse útiles y apreciadas, tanto más cuanto que sus individuos son alistados voluntarios que obran con desinterés. Ya resulta admirable que hayan podido subsistir en medio de tantas dificultades. Todas las realizaciones que tienen en su haber eran muy superiores a sus fuerzas; sólo las impulsó y llevó a cabo el gran incentivo del amor al bien común y el ansia de servir a la Patria. Pero, al cabo de tantos años, el Gobierno no puede seguir esperando y exigiendo de ellas que se sacrifiquen sin recibir la menor contrapartida, sin el menor aplauso o estímulo. No está además en condiciones de pretenderlo, ya que trabajan de balde.

Las Sociedades requieren al Rey y al Consejo en términos apenas velados para que manifiesten de modo concreto y positivo su aprecio y protección. Las Sociedades no imploran. Reclaman que se publique su ingrata y abnegada labor en pro de la nación y de la felicidad pública; que el Rey exprese su agradecimiento y dispense gracias a proporción de los méritos contraídos por los socios. Exigen trabajar en estrecha y constante colaboración con el Gobierno, ya que esta colaboración es la razón de su propio ser. Quieren poder contar con su ayuda incondicional para llevar a cabo sus empresas. Exigencia muy legítima y muy justificada en un momento en que la Superioridad daba la impresión de alejarse cada vez más de las Sociedades, de abandonarlas a un trabajo estéril, frenando o traicionando sus proyectos y confinándolas en sus meditaciones y raciocinios. La culpa de la decadencia, es un hecho innegable, la tiene el Gobierno que no respalda su acción patriótica como era de esperar y parece desinteresarse de ellas, de sus móviles y política. Así lo dice la matritense en tono cargado de escepticismo y desencanto: "Si las miras del Gobierno coincidiesen con las de la Sociedad, se evitaría esta amarga censura y enmudecerían los que tanto claman, si se acercasen a examinar las cosas con datos fijos” ${ }^{71}$.

Las Sociedades no han desmerecido, pero el Gobierno y el Rey tienen que cumplir sus promesas en gran parte olvidadas. Sin la rigurosa observancia de estos compromisos, las Sociedades no serán más que castillos en el aire y es fácil pronosticar su ruina definitiva.

71 S. E. M., leg. 79/10. 


\section{TRAMITACION ULTERIOR DEL EXPEDIENTE}

Una vez constituido el expediente, es decir después de llegar al Consejo la contestación de MADRID que cerró la encuesta el 15 de julio de 1787 , pasaron los informes, según estaba previsto, a la Junta de Recopilación integrada por cuatro Consejeros de Castilla cuyas firmas nos resultan familiares: D. Fernando Joseph de Velasco. D. Blas de Hinojosa, D. Miguel de Mendinueta, D. Manuel de Lardizábal y Uribe. Le incumbía a la Junta examinar las relaciones de las distintas corporaciones, clasificar los principales argumentos y reivindicaciones de los socios y señalar al Consejo los que por su carácter general, urgente o juicioso, merecerían, en su opinión, tenerse en cuenta. Este trabajo preparatorio iba destinado a los Fiscales quienes dictaminarían en última instancia. Lo ejecutó con toda celeridad la Junta, dado el volumen de los documentos a compulsar y mes y medio escaso después, la concluyó con fecha de 10 de setiembre de $1787^{72}$.

Ese informe que ocupa siete folios recto verso es un análisis llevado con inteligencia, clarividencia y simpatía. Sientan los euatro Consejeros como primer axioma que las Sociedades desempeñan un papel de suma importancia y que han dado ya "pruebas nada equívocas de su utilidad en beneficio común y particular de los pueblos». No se trata pues de poner a discusión la existencia de las Sociedades económicas: «...Son el medio oportuno y a propósito, prosiguen, de que puede valerse un Gobierno ilustrado para llevar a su perfección la agricultura, las artes, la industria y el comercio, bases esenciales de la felicidad y poder de una monarquía. Son por tanto acreedores a toda la protección del Rey y de V. A. y a que se das fomente por todos los medios posibles y se les procure una subsistencia sólida y permanente». La postura de los Consejeros no puede ser más favorable. Distinguen dos causas principales a la decadencia sufrida por varias Sociedades: la falta de fondos y la poca o ninguna estimación que por lo general se hace de ellas y de sus individuos. En esta segunda causa, se incluyen desde luego otras muchas que señalamos (clima desfavorable, trabas gubernativas y administrativas, ingratitud del Gobierno).

72 Este documento se encuentra en el mismo expediente del A. H. N., leg. 3658/11, sección Consejos. 
Los Consejeros hablan claro. Siendo los gastos de las Sociedades, dicen, numerosos e ineludibles, necesitan éstas un fondo fijo para llenar los fines de su instituto. Con hacer una imposición de un $3 \%$ sobre los sobrantes de los Propios, así como de los expolios de las mitras y de la tercera parte beneficial, se podría solucionar fácilmente este punto, opina la Junta. E1 poco aprecio de que se quejan las Sociedades, tiene también que tomarse en consideración. No hay que olvidar que las ocupaciones gravosas de las Sociedades no traen a sus individuos ninguna clase ide provecho. Si, encima, recogen el menosprecio del público y del Gobierno, desmayarán y las abardonarán. Es preciso, pues, premiar sus desvelos tal como lo desean, hacien. do constar los méritos contraídos por los socios pretendientes en sus hojas de servicio, distribuyendo mercedes y condecoraciones a los más eminentes y abnegados. Además, hay que facilitarles sus tareas, quitando de su camino los numerosos óbices que encuentran y exigiendo firmemente de todas las autoridades que protejan, promuevan las Sociedades y las consulten en asuntos económicos. Conviene por fin que el Consejo dedique un día cada semana al despacho de los negocios de las Sociedades, porque piden la más pronta expedición.

Todos estos medios que sugieren los mismos Cuerpos para recobrar actividad, prestigio y eficacia, la Junta los estima oportunos y nada exorbitantes, respecto de las ventajas que se pueden esperar de unas Sociedades bien establecidas que serán, vaticinan «otras tantas escuelas de economía civil, ciencia absolutamente necesaria para la prosperidad de un Estado». Tal es, en lo esencial, el fallo de la Junta de Recopilación, pero su escrito merece extractarse algún tanto por las consideraciones, ya prácticas, ya filosóficas con que lo acompañan. ... «Para desempeñar debidamente las Sociedades los fines de su instituto, no basta que instruyan e ilustren al público con sus escritos y especulaciones. Este medio, aunque muy útil y oportuno, por sí sólo es insuficiente para desarraigar ciertas preocupaciones y usos inveterados, que por lo común ison los mayores impedimentos para el adelantamiento de la agricultura y de las artes. Por más que una Sociedad se empeñe en hacer ver, por ejemplo, que el modo con que en un país se cultiva la tierra es imperfecto y que podría mejorarse o sustituírsele otro más útil y ventajoso; que un instrumento nuevo es mejor que los antiguos; que con una máquina pueden adelantarse y mejorarse ciertas maniobras, etc..., nunca será creída sobre su palabra (y esto es muy puesto en razón) si no hace ver antes prácticamente y con repetidas experiencias las utilidades y ventajas que intenta persuadir por escrito. Para hallar un descubrimiento verdaderamente útil, suel. ser necesario hacer antes muchas tentativas y pruebas costosas sin otro fruto que gastar dinero. Es también 
necesario para adelantar y perfeccionar las artes y oficios, establecer escuelas gratuitas de dibujo, fondos de anticipación de primeras materias para distribuirlas a los artesanos y menestrales que no tienen facultades para comprarlas; mejorar o establecer de nuevo escuelas de primeras letras, de hilado, de cosido, etc., y repartir también algunos premios.

Sin estos establecimientos y otros semejantes, no hay que esperar utilidad ninguna verdadera de las Sociedades. Pero ¿cómo podrán éstas ponerlos en ejecución, si no tienen un fondo fijo y competente? La contribución de los socios, sobre ser insuficiente en si misma, tiene bastantes quiebras, pues según consta de los informes, son muchos los que no la pagan y las Sociedades no tienen ni deben tener facultad para exigirla por fuerza. La liberalidad de algunos sujetos acaudalados y amantes del bien público, sobre no ser muy común, es un fondo muy incierto y sobre que no deben contar prudentemente las Sociedades para empeñarse en empresas, sin el peligro de verlas frustradas al mejor tiempo por mil contingencias. Es pues absolutamente preciso que se doten las Sociedades con fondos fijos y competentes; pero también es igualmente necesario que éstos se inviertan única y precisamente en los fines del instituto y de ningún modo en sueldos ni dotaciones de los empleos de las Sociedades, porque entonces sería peor el remedio que la enfermedad.

...Es verdad que el amor a la patria y el bien de ella debía ser el mayor estímulo y al mismo tiempo el premio de los que se dedican a servirla. Pero esta máxima, aunque tan justa y verdadera, no es la que gobierna al común de los hombres, y éstos han de ser dirigidos y rrobernados, no con respecto a lo que debieran ser, sino a lo que son en realidad, siendo preciso condescender muchas veces con ciertas flaquezas y defectos para sacar el partido que se pretende. De lo contrario sólo se conseguirá persuadir en vano y dictar reglas muy justas a la verdad y muy razonables en sí, pero inútiles e incapaces de producir efecto alguno.

Por una preocupación del todo contraria a la máxima propuesta, pero que ciertamente tiene más fuerza que ella, toda ocupación que no se dirige al interés particular de cada uno, se mira por lo general como una extravagancia propia sólo para perder el tiempo inútilmente. Esta preocupación que se extiende al instituto de las Sociedades, es la que se debe combatir, procediendo de un modo inverso, esto es, haciendo verdaderas y prácticamente apreciables y de estimación las ocupaciones y trabajos de las Sociedades. Esto sólo puede hacerlo el Gobierno y lo conseguirá infaliblemente premiando y remunerando a los que, con buen celo y verdadera utilidad del público, se dedican a trabajar en las Sociedades. No haciéndolo así, en 
vez de destruir la preocupación, contribuirá el mismo Gobierno por su parte a fortificarla más, porque en el hecho de no premiar los trabajos de las Sociedades, da a entender bien claramente que los mira como inútiles, puesto que premia los de las demás carreras y ocupaciones que están reputadas por verdaderamente útiles...

Cree la Junta que los que con celo y aplicación se dediquen a estas ocupaciones, son tan acreedores a las gracias y especial protección del Soberano, como los que siguen las otras carreras y profesiones necesarias para el buen gobierno de una república y que igualmente contribuyen a su felicidad, y sin lo cual es imposible que las Sociedades prevalezcan ni hagan los progresos que tan justamente desea el Rey y V. A...)

Luego, desviándose de la línea general, la Junta somete a la atención particular del Consejo, una solicitudes específicas que juzga necesitar satisfacción inmediata. VERA por ejemplo quiere concluir un camino y un canal y pide para ello que se declare pertenecerle el impuesto de dos reales en cada quintal de “cáñamo» ${ }^{73}$ que vendió a la Real Hacienda. Medina de Rioseco reclama con justicia que le sea atribuida la nueva contribución de 4 maravedíes por cántaro de vino de su propia cosecha, que wa a parar anormalmente a las cajas de la Sociedad de valladolid. La bañeza solicita 50.000 reales que le pertenecen y que se niegan a abonarle los recaudadores de los bienes del Común, por falta de instrucciones de la Real Hacienda, así como las cantidades ya devengadas que algunas cofradias se han comprometido a depositar en sus arcas. En fin, muchas instancias de GRAN CANARIA (sobre revocación de datas en ciertos terrenos, extinción perjudicial de las dos sisas del vino y del aguardiente, infeliz estado de la Casa de Expósitos) claman por una urgente solución. Convendría pues separar del general estos expedientes y tratar aquellos puntos en prioridad.

La Junta de Recopilación cierra su informe en estos términos: «Esto lo hace presente a V. A. para que resuelva lo que tuviere por más conveniente», Madrid, 10 de septiembre de 1787.

El texto que acabamos de analizar suscita unos breves comentarios. Ya hemos señalado el tono de comprensión y firmeza en que está redactado. Los cuatro Consejeros conservan intacta su fe en las Sociedades Económicas y abogan en su favor. Por eso, sin duda, han descartado la menor alusión a posibles desavenencias o partidos. Tampoco hablan de la «tibieza»

73. En realidad, se trata del esparto, planta muy distinta del cáfinmo. 
que se ha apoderado de muchos Cuerpos ni de las insuficiencias humanas que entorpecen a veces la marcha de aquellas corporaciones. Resaltan únicamente los aspectos positivos: servicio a la patria, eficacia, abnegación. Y para completar el cuadro, hacen hincapié en el desaliento muy legítimo de los socios que se juzgan despreciados a pesar de todos los sacrificios consentidos en pro de la nación. Así piensan disponer favorablemente los ánimos de los jueces que estatuirán sin apelación.

Otra particularidad llama la atención. Los Consejeros no recogen el argumento de la excesiva proliferación de las Sociedades como factor de decadencia y no emiten opinión a ese respecto. El hecho no deja de sorprende: cuando salta a la vista que tan desenfrenada, irracional y casi incontrolada diseminación de Sociedades, iba a debilitar considerablemente todo el sistema y provocar su desmoronamiento.

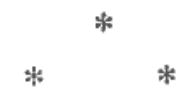

Casi un año tardaron los Fiscales del Consejo en extender el dictamen que tenían que presentar al alto Tribunal. El documento, bastante enrevesado y confuso, Ileva la fecha de 16 de agosto de 1788.

Los Fiscales ${ }^{74}$ se adhieren totalmente al parecer de la Junta de Recopilación a la cual citan en ocasiones. Confirman las dos causas de decadencia principales: la falta de fondos y el poco aprecio que se hace de los Cuerpos Pafrióticos. Se ve que han estudiado a su vez el abultado expediente en toda su extensión, ya que señalan como más constructivas las contestaciones de SANTIAGO, GRAN CANARIA, ZARAGOZA y por supuesto MADRID. Aprueban lo que dijeron Santiago y Gran Canaria acerca de la remuneración del celo y trabajo de los socios y observan que la Junta de Recopilación en sus comentarios adoptó muchas sugerencias de Santiago.

La única novedad de su informe es que recoge una idea que la Junta había dejado de lado: la reducción del número de Sociedades Económicas. Creen los Fiscales que la providencia resultaría provechosa: «Los gastos podrían ser menos sin comparación, si sólo hubiese una Sociedad en cada ciudad Capital de provincia, o en las de Partido considerable, cuando

74 En los años $1786-1788$ en que se airea este asunto de las Sociedades, servían la fiscalia del Tribunal D. Jacinto Moreno Montalvo, D. Antonio Cano Manuel y D. Manuel Sisternes Feliú. 
ésta fuese muy dilatada, reduciéndose las demás Sociedades de pueblos cortos a unas Juntas de caridad o comisión con dependencia de la Sociedad de la capital de provincia. De este modo se excusarían muchos gastos y economizarían otros, teniendo en aquel pie las Sociedades subalternas o Juntas de caridad individuos bastantes que hiciesen sus respectivos empleos, y no se tocarían los inconvenientes de que habla con bastante conocimiento la Real Sociedad de Zaragoza. Y así se ve que no pueden prosperar por defecto de conocimientos y proporciones para adquirirlos las que hay en el reino de Sevilla, separadas de la Capital y lo mismo en el de Granada, advirtiéndose alguna $u$ otra en el reino con empleo de los principales en blanco, sin duda por no haber sujeto proporcionado que los desempeñe».

Para dar pronto curso a las solicitudes de las Sociedades, opinan los Fiscales que deberá el Consejo dedicar un día por semana al examen de asuntos y estudiar cada informe por separado. Rinden homenaje a la laboriosidad, desinterés y generosidad de la matritense. "Consta al Consejo la multitud de informes que ha despachado y se la han pedido sobre arreglo de ordenanzas de todas las Sociedades del Reino. El celo y actividad con que ésta ha seguido y continúa desde su creación mlerece que se la distinga y excluya del concepto de decadencia que en el Real ánimo de S. M. tienen todas las demás del Reino, según indica en la Real orden... y así conviene se le haga presente para satisfacción de este Cuerpo, que tanto se esmera en los adelantamientos de su instituto».

Concluyen los Fiscales su algo verbosa exposición indicando el curso que ha de darse al asunto: "Que se ponga todo en noticia de S. M., que se separen estos expedientes y se pase cada uno al Fiscal del respectivo departamento... para su pronto despacho y concurrir a los medios que propone cada Sociedad para su restablecimiento"s.

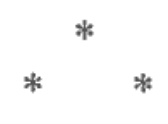

Este "pronto despacho" que al parecer deseaban tanto los Fiscales para acudir en auxilio de las Sociedades, no tuvo lugar. La encuesta sobre la decadencia llevada a tambor batiente no surtió ningún efecto. Una vez más, se verificaba lo que habían denunciado los oficiales en sus informes y seguían temiendo: cuando llegaban sus representaciones a la Corte, se traspapelaban en las covachuelas, o se perdían en la antecámara del Consejo y ya no se oía hablar de ellas. Este no fue sino un caso más. El lector 
se preguntará si no cabe otra explicación que el excesivo trabajo o la negligencia del Consejo. Es muy posible en efecto.

E1 dictamen de los Fiscales es de agosto de $1788^{15}$. Cuatro meses más tarde muere el Rey, sucediéndole Carlos IV a principios de 1789. Es lógico que estos acontecimientos hayan provocado cierta indecisión, incluso cierto paro en los grandes cuerpos del Estado. En 1789, se divisan las primeras señales de la Revolución en el país vecino. Puede que unas corporaciones como las Sociedades que se gloriaban de hablar con «aquella libertad y franqueza nacidas de la filosofía), hayan inspirado algo de recelo al Rey y a sus ministros. Bien pronto, como es sabido, se instalará un verdadero cordón sanitario a lo largo de la frontera pirenaica y en los principales puertos de la península para impedir la entrada en España de una prensa cada vez más filosófica, liberal y luego revolucionaria. Las justicias y los Tribunales dan caza en todo el país a los libelos y panfletos. Pero las cosas van de mal en peor. En 1792, se declara la guerra a la Convención regicida y el conflicto que agota, no sólo al real Erario, sino también los recursos de la nación, moviliza la atención de todos, gobernantes y súbditos.

Las Sociedades Económicas, muchas de las cuales han dejado de celebrar juntas durante esos aciagos años, quedan marginadas y completamente olvidadas. Y si se piensa en ellas, tal vez no sea para bien, pues en algunos medios se critica la actitud de los Caballeros de Aizcoitia. Firmada la paz de Basilea, España restaña sus heridas y vuelve despacio a la vida normal. La creación del Semanario de Agricultura en 1797, cuyo primer número encabeza una carta de Godoy, muestra que las preocupaciones económicas sustituyen a las militares en el espíritu del Rey y de su valido. Las Sociedades reanudan sus actividades casi paralizadas, o por lo menos muy apagadas durante largo tiempo. Se acuerdan entonces de la encuesta gubernamental realizada doce años antes y que no ha dejado rastro. En 1798, santiago refresca la memoria del Consejo, pidiendo aclaraciones sobre el particular en una carta que dirige al Secretario de Estado, D. Francisco Saavedra. Este consulta al Consejo: "La Sociedad Económica de Santiago ha hecho presente al Rey que en 14 de julio de 1786 recibió una circular del Consejo para que informase acerca de las causas de su decadencia... y dice que su contestación y las demás de las Sociedades pasaron a

75 Esta pieza está incluida en el expediente del A. H. N., leg. 3658/11 de la sección de Consejos. 
la Junta de Código ${ }^{76}$ en donde se han estancado, sin que haya resultado providencia alguna. S. M. quiere saber lo que resulta de estos informes y que sobre ello consulte el Consejo lo que se le ofreciere... ${ }^{7}$.

Desgraciadamente, no se le ofreció gran cosa al Consejo. Quizá porciue los acontecimientos, una vez más, se interpusieron entre el deseo del Rey y su realización. En Agosto cayeron destituidos Jovellanos y Saavedra, Iuego estalló la guerra con Portugal, Caballero ocupó la Secretaría de Estado... Sólo a raíz del año calamitoso de 1804 en que las Sociedades existentes y las juntas de caridad hicieron milagros para salvar a miles y miles de indigentes o de artesanos y menestrales desprovistos de todo, se acordó el Gobierno de los Cuerpos Patrióticos y mandó al Consejo que tratase de dar curso al expediente arrinconado. Los Fiscales cavilaron cierto tiempo sobre él, pero su dictamen, dado en 14 de agosto de 1805 , o sea siete años después del recuerdo del Secretario de Estado Saavedra, no fue nada alentador:

«No dudándose que el medio más efectivo de fomentar el establecimiento de las Sociedades Económicas sobre que trata este expediente por encargo de S. M., es facilitar a esos Cuerpos fondos con que atiendan al desempeño de su instituto, en lo que convienen todos los informes, no es fácil ni aun posible en el día, mediante el estado que tienen los caudales públicos de los pueblos, que es lo que se propone, por las notorias y graves urgencias y necesidades que han sufrido y continúarl al presenten.

«El otro medio en que convienen los informes se reduce a facilitar la estimación de estos Cuerpos y dispensar algunas gracias y distinciones a los individuos que se esmeran por su celo. Esto último es propio de la disposición de S. M. y en cuanto a lo primero, no hallan reparo los Fiscales en que se haga encargo a los Tribunales Provinciales sobre que en los negocios que ocurran análogos al instituto de las Sociedades, procedan en

76 En los últimos años del siglo XVIII, empezó a darse a la hasta entonces llamada Junta de Recopilación el nombre de Junta de Código, por influencia de Francia. Como el expediente volvió a surgir del olvido en 1795, es fácil que los socios gallegos o más probablemente el secretario de Estado D. Francisco Saavedra haya empleado por equivocación el nombre de Junta de Código en vez de junta de Recopilación. (Información que agradecemos a nuestro amigo D. José Antonio Martínez Bara, vice-director del A. H. N.).

77 Nota del Secretario de Estado, D. Francisco Saavedra, Aranjuez, 17 de junio de 1798, A. H. N., Consejos, leg. 3658/11. 
ellos tomando informes de ellas, a imitación de lo que ejecuta el Consejo con la de esta Corte” ${ }^{78}$.

Después de conceder esta pobre satisfacción a las Sociedades, citan expresamente los Fiscales los casos de las Sociedades de vera y medrna de Rioseco, evocados por la Junta de Recopilación en 1787, como necesitando el más pronto despacho. Pensando que la primera, con una perseverancia en que veinte años o casi no hubieran hecho mella, sigue pidiendo una prórroga para el reintegro de los 30.000 reales adelantados por el Rey sobre los Propios, los Fiscales contestan con toda seriedad: "Las razones que expone son fundadas, pero sin embargo, convendrá que la Junta de Propios y el Ayuntamiento informen el estado que tiene este punto y la disposición en que se halla, así el caudal de Propios como los fondos de la Sociedad». ¡Triunfo del papeleo! Llevar el expediente a un punto muerto, dejar que coja moho, olvidarlo por completo, volver a sacarlo al cabo de 19 años para otra vez empezar a cero, ponerlo todo en tela de juicio, y eso siguiendo las normas de la más imperturbable formalidad administrativa!

Más pintoresco y divertido aún es el caso de medina de rioseco. Recuerdan los venerables togados que esa Sociedad solicitaba en 1787 la aplicación del impuesto de cuatro maravedíes por cántaro de vino de su cosecha, que se había concedido a favor de Valladolid. El comentario de los Fiscales es de antología: «Se presenta deferible esta pretensión, pero a fin de asegurar el acierto, convendría que la Sociedad de Valladolid informe con remisión de la orden en que se le concede este impuesto, exponiendo cuanto se le ofreciere y pareciere». No se les ocurrió a los dignos ministros preguntarse "para asegurar el acierto» en qué situación se encontraba en 1805 la Sociedad de Medina de Rioseco. Ahora bien, hacia quince años, en aquella fecha, que había dejado de existir.

Hermoso ejemplo éste, de tozudez y estupidez administrativa, en que la noria seguía dando vueltas con las reglas y ritmo de siempre, pero nadie se había dado cuenta de que los cangilones subían vacíos!

Triste epílogo también para los Cuerpos Patrióticos que vieron por enésima vez sus justas pretensiones rechazadas. Había sonado para ellos el toque de agonía. Ya desde 1787, el silencio de mal agüero del Gobierno los había condenado a morir de consunción.

78 El dictamen de 1805 de los Fiscales se encuentra en el expediente de A. H. N., leg. $3658 / 11$, antes citado. 


\section{CONCLUSION}

Al final de esta detallada exposición, ya podemos discernir dos razones esenciales, sacadas de la argumentación de los mismos socios, que explican el lento e ineluctable ocaso de las Sociedades Económicas. En primer lugar, todos los defectos y anomalías de que adolecian en sus estructuras; en segundo lugar, la negativa del Gobierno de enmendar aquellos Cuerpos y prestarles el auxilio que necesitaban.

Cuando, entusiasmados por los comienzos alentadores y sobre todo las extraordinarias posibilidades que ofrecía la SOCIEDAD BASCONGADA erigida gracias al celo del conde de Peñaflorida, Campomanes y el Rey proyectan favorecer la implantación de corporaciones similares en todo el país, piensan haber encontrado algo como la panacea universal, el medio de salvar a la nación de los males que venía padeciendo desde hacía dos siglos y se iban agudizando año tras año. La ociosidad, la mendiguez, la rutina e ignorancia, el marasmo y el retraso económico, todas estas plagas que afligían a la península, desaparecerían poco a poco y saldría una nueva España, de cara limpia y sana, dotada de nuevo vigor y resueltamente abierta al progreso. El pueblo, debidamente instruído y capacitado bajo la vigilancia de las Sociedades, sería el protagonista de aquel resurgimiento. Entonces, Campomanes plasma estos nuevos conceptos ideológicos en dos libros notables; el Discurso sobre el fomento de la industria popular, Madrid, 1774, y el Discurso sobre la educación popular de los artesanos y su fomento, Madrid, 1775-1777, que van a ser el código y la Biblia de los Amigos de! País.

En el sistema planeado, todo se haría como por milagro. Apenas tendría que intervenir el Estado. Mientras la máquina gubernamental, armatoste antiguo y venerable, tal vez imposible de remozar y hacer evolucionar, se guiría ronroneando con su ritmo tradicional, iría cambiando paulatinamente el país, se enriquecería, se imbuiría en las luces, sólo con el capirotazo inicial de una Real Orden. Los que supieren, enseñarían a los demás a salir de su incultura y ociosidad, a leer y escribir, a hilar, coser, cultivar racionalmente los campos, a perfeccionar artes y oficios, a ponerse a nivel de los pueblos más adelantados de Europa. Serían las Sociedades Económicas unas escuelas permanentes del saber en las que hombres, mujeres, ióvenes y niños, en cada momento, podrían adquirir nuevos conocimientos. Muy rápidamente, en todas las capas populares, se extendería como mancha de aceite la instrucción, base imprescindible para la edificación de una sociedad moderna y progresista. Enseñado a trabajar y a ganarse la vida, 
el pueblo viviría mejor y sería más feliz. Huelga recalcar los beneficios que resultarían al país «si tantas manos indebidamente ociosas, se ocupasen con utilidad propia y del Estado» ${ }^{79}$.

Esta milagrosa y pacífica revolución de las costumbres y de la sociedad, se haria -cosa notable- fuera de las instituciones rectoras de la monarquía. La salvación vendría de la iniciativa privada, como en el caso de LA BASCONGADA, de un amplio movimiento de buenas voluntades. Los nuevos Cuerpos Patrióticos disfrutarían de gran latitud de acción; estarían sólo vinculados al Gobierno a través de la persona del Rey, su protector nato, y de su brazo ejecutivo, el Consejo de Castilla. Estarían pues a salvo de todas las pejigueras y engorros administrativos, ya que el monarca había recomendado a todas las autoridades allanasen el camino a las Sociedades y no se interpusiesen para estorbar sus operaciones.

Otro hecho no menos admirable: funcionarian y trabajarían las Sociedades de forma absolutamente gratuita, «sin gravar el Erario», se recalca una y otra vez en los documentos relativos a aquellas corporaciones. Cambiar la mentalidad de un país, modificar diametralmente su economía, comunicarle las luces del siglo, hacerlo feliz, sin que gaste el Estado una blanca, he aquí otra hazaña, otro milagro, y no el menor. Hoy, tales disposiciones nos parecen, más que utópicas, disparatadas y hemos visto por las relaciones de los socios, que lo fueron también en su tiempo.

Pero los gobernantes confiaban en que darían las Sociedades los resultados esperados, porque creían poder contar indefectiblemente con una palanca poderosa, irresistible: el patriotismo. Los Amigos del País eran, por antonomasia, unos patriotas. Colocaban a la patria muy por encima de sus mezquinos intereses. Voluntaria y espontáneamente, en un gran arranque de generosidad $y$ de idealismo, se alistaron numerosos en las filas de los Cuerpos recién creados. Pero el altruismo entraña siempre algún sacrificio, alguna renuneia, y construir toda una vida sobre estos incómodos fundamentos es el hecho de héroes o de santos. Los Amigos del País eran unos excelentes patricios, de corazón noble y abnegado, pero su heroicidad o santidad tenía sus límites, y a la larga, decepcionados, amargados al verse relegados, despreciados, menos útiles de lo que habian soñado, dejaron amortiguarse en ellos la primitiva llama ardiente y purificadora del patriotismo. Del erisol apagado, subieron los humos de las pasiones y flaquezas humanas redivivas. Uno de los errores psicológicos más patentes

79 Real Cédula de 18 de Noviembre de 1774, A. H. N., Cédula 393. 
que cometió el Estado fue pensar que se podía erigir toda una construcción humana duradera sobre el patriotismo y exclusivamente sobre él. Como lo recordaron muchos de los informantes de 1786, el interés y el honor son los dos polos entre los que se mueve el hombre. Pese a unas vagas promesas del Rey, no se hizo nada o casi nada para estimular aquellos resortes de la actividad humana. Al cabo de varios años, el motor milagroso, el patriotismo que animaba toda la máquina de las Sociedades, falto de aliciente o de combustible, dio señales de cansancio, tuvo fallos y, en ciertos casos, paró por completo.

Tampoco pudo funcionar la máquina sin lo que se suele llamar «el nervio de la guerra», sin dinero. Agotados los veneros de los donativos, ya insuficientes $\mathrm{y}$ con mucho! para atender a todas las necesidades del instituto, se redujeron los ingresos a las contribuciones de los socios, ellas mismas aleatorias. Perdida la fe, entibiado el entusiasmo, faltas de subsidios, las Sociedades fueron a menos en la mayoría de los casos.

Desde un principio, pues, carecieron de estructuras las Sociedades. Edificadas sobre esa premisa de un milagro continuado - cuando el milagro es por esencia, como el rayo, momentáneo--, no pudieron sostenerse. Se ha dicho y repetido hasta la saciedad que los Amigos del País fueron unos utopistas, desprovistos de toda clarividencia, unos como ilusionistas que se movían sin son ni ton entre las nieblas de sus ensueños. Tal enfoque, constituye, a nuestro modo de ver, un error de perspectiva notable, y para convencerse de esta falacia, si fuera necesario, basta el examen del expediente que hemos manejado. El utopista fue sin duda el creador de ese ambicioso proyecto, quien no supo acompañarlo con todas las garantías que hubieran asegurado su éxito, o no pudo imponer estas garantías. De la teoría a la práctica, media un abismo y los Amigos del Pais hicieron la dolorosa experiencia de esta cruel verdad. Lanzados de buena fe a aquella aventura, prontamente se dieron cuenta de todas las deficiencias del sistema. El severo y riguroso análisis que hacen de las causas de su decadencia las Sociedades, es objetivo, penetrante y coherente. No es de utopistas. La gran preocupación de eficacia que movía a los socios estribaba forzosamente en una visión realista de la situación. Y realistas lo son en todas sus empresas. Nada inútil, nada superfluo, nada que no sea concreto y no responda a una necesidad (;pero son tantas!) en su programa de acción. Discuten, cavilan, raciocinan, elaboran planes, pero siempre con miras a una aplicación directa de sus principios. Cuando no llevan a cabo sus proyectos, es que unos obstáculos imposibles de remover con sus solas fuerzas se yerguen en su camino. 
De ser aceptada por el Gobierno la gama variadísima y muy completa de reformas y mejoras que preconizaban las Sociedades, hubiera cambiado la fisonomía de aquellos Cuerpos y a través de ello tal vez, algo de da fisonomia general del país. Pero ya sabemos que el Consejo, no haciendo ningún caso de las conclusiones de aquel análisis alarmante, menospreció soberanamente a todas las reivindicaciones de las Sociedades, fuesen satisfacciones morales o financieras. Manifestó el Consejo una muy lamentable desidia en la etapa final de los trámites del expediente, e, incluso, parece que no comunicó a Carlos III el resultado de la averiguación realizada, ni tampoco los dictámenes favorables de la Junta de Recopilación y de los Fîscales ${ }^{80}$. No se lució mucho, por cierto, en este asunto, y tenemos fuertes motivos para creer que echó tierra al expediente, ahogando así todos los gritos de ansiedad que contenía.

¿Por qué? Nuevamente, hay que interrogarse para intentar aclarar este hecho inaudito. En efecto, laj actitud del Gobierno no deja de constituir una gran paradoja. Fomenta primero, con gran interés, la implantación de Sociedades en todo el territorio, y transcurridos algunos años, les va escatimando cada vez más su apoyo, condenándolas a la impotencia. Y cuando, aprovechándose de la ocasión inesperada que se les ofrece, éstas claman su indigencia, su abandono, su desaliento, se encierra el Consejo en un mutismo absoluto, no acude en su auxilio, en una palabra, parece traicionarlas. Actitud más inexplicable aún cuando se sabe que el conde de Campomanes, promotor de aquellos Cuerpos Patrióticos y socio de varios de ellos (MADRid - VAlencia - SEVILla - OVIEDo - ALAEJOS - SANLÚCAR DE BARRA* MEDA - VÉLEZ MÁLAGA y probablemente algunos más) pertenecía al Real Tribunal en aquellas fechas. Si recordamos que en 1774, todavía Fiscal del Consejo de Castilla y gozando de enorme prestigio, obtuvo del Rey que su Discurso sobre el Fomento de la Industria Popular se publicase en 30,000 ejemplares y se difundiese por todo el pais j,ómo entender que en aquellas circunstancias particularmente inquietantes y de gran malestar, no influyese personalmente para que el Tribunal examinase con preferencia el asunto de las Sociedades? Lógicamente, tenía que abogar en su favor. La encuesta había sido un éxito. De las 42 Sociedades consultadas, 35

80 Recordemos los términos en que está redactada la nota del Secretario de Estado, D. Francisco Saavedra, en 1798 (véase pág. 175). Ni el Rey ni la Secretaría de Estado están al tanto del asunto. No obra en el expediente 3658/11 del A. H. N. minuta alguna de la consulta que el Consejo debía hacer a S. M. y tal idocumento no llegó nunca al parecer a extenderse. Por lo visto, todo se quedó estancado en el Consejo, como lo pretendía Santiago. 
en total habian contestado, es decir las cinco sextas partes, cifra que demostraba el interés que había despertado la circular del Consejo y el deseo de todas de aumentar su eficacia. Las respuestas eran sensatas, inteligentes, constructivas y revelaban que, en palabras de GRAN CANARIA, "se podía fiar de las Sociedades»). Y por fin, tanto la Junta de Recopilación como los Fiscales reconocían la legitimidad de sus quejas y peticiones, resaltando al mismo tiempo la utilidad de sus trabajos.

En vista de estas conclusiones alentadoras, Campomanes debía, valiéndose de su posición, obtener la aquiescencia definitiva del Consejo y la ratificación real. ¿Por qué las cosas no siguieron más adelante? ¿Se desinteresaría entonces Campomanes de sus creaciones? Parece inverosímil. ¿No estaría en condiciones de hacerlo? ¿Se enfrentaría con una fuerte oposición a sus teorías y política en el seno del Tribunal? ¿Había perdido el favor del Rey y el prestigio de que gozaba ante sus colegas? Nada de eso. No se había empañado ni ofuscado su estrella. Al contrario. En aquellas fechas de 1786-1788, después de servir durante tres años (1783-1786) interinamente la plaza de Gobernador o Presidente del Consejo, ocupaba aquel cargo preeminente en propiedad y lo conservaría hasta su dimisión en 1791 . ¿Cómo, entonces, investido de tales poderes, condenó a la asfixia, ar la muerte lenta - porque en este particular no podía engañarse- aquellos Cuerpos deseosos de cooperar con el Gobierno? Hay aquí un enigma, un punto incomprensible. El mismo misterio y la curiosidad incitan a edificar hipótesis:

Quizás prefiriese Campomanes arrinconar el expediente y permanecer callado porque los documentos reunidos constituian unas pruebas de semifracaso de sus teorías y no podría menos el Rey de percatarse de las deficiencias del sistema. Tal descubrimiento hubiera hecho posiblemente incurrir a Campomanes en la desgracia real en el momento en que, Ilegado al pináculo de los honores, entendía no arriesgar su posición. Aplazaría pues hábilmente la tramitación final del expediente y se borró de la memoria del Rey el asunto. Poco después, la muerte del Soberano iba a marcar un hiato propicio y los nuevos asuntos originados por la intronización de su sucesor acapararian la atención del Consejo.

Otra explicación posible: El conjunto de los informes, no era sólo un apretado haz de quejas, recriminaciones y reivindicaciones. Constituía un verdadero proceso de intención al Consejo. EI tono de las protestas no dejaba de ser en ocasiones atrevido y hasta irreverente. La libertad con que hablaban los socios cobraba a veces visos de enérgica acusación. Las Sociedades sentaban al Consejo en el banquillo. Era él, el verdadero reo, cul- 
pable de dejar periclitar los Cuerpos Patrióticos. Se subrayaba cruel y reiteradamente su morosidad administrativa, su inmovilismo, su falta de política general, sus miras discordantes de las de los Amigos del País, su actitud reacia frente a las «novedades». Abrumaba a las Sociedades de trabajo - en especial a LA MATRITENSE- pidiéndole a cada instante informes de toda clase, y ellas sacaban escaso fruto de tantos desvelos. Además, la visión que daban las Sociedades de provincias de las capitales o pueblos donde residían, era poco halagadora. En muchas partes, había señales, no sólo de miseria, sino también en las autoridades locales, de desobediencia, de autoritarismo, de abusos y atropellos y no siempre el Consejo bastaba para restablecer el equilibrio e imponer la ley. En tales condiciones, hubiera sido insensato presentar al Rey testimonios tan manifiestos de cierta incuria e indolencia del Consejo, y Campomanes, prudentemente, se abstuvo. Prefirió dejar que las cosas siguiesen su curso fatídico.

Estas dos hipótesis, desde luego, no se pueden, de momento, respaldar por ningún documento; pero no son inverosímiles. Es muy conocida la habilidad maniobrera y según lo que afirman unos el oportunismo político de Campomanes. Recuérdese lo que contestó a Jovellanos en 1790, cuando éste acudía a Madrid en auxilio de su amigo Cabarrús: «Vm. quiere ser heroico; yo no puedo serlo».

El hecho es que no se llevaron a la práctica ninguna de las mejoras solicitadas por las Sociedades. ¿Resultarían demasiado onerosas? No. El $3 \%$ sobre los Propios aprobado por los Ministros de la Junta de Recopilación era una exigencia muy razonable en aquellos años. $Y$ las Sociedades estaban dispuestas a conformarse con un $2 \%$. ¿Seria que las condecoraciones y honores pedidos por los socios fuesen desproporcionados a sus méritos? Tampoco nos parece que lo fueran. Pero, admitiendo por un momento esta interpretación, ¿por qué entonces no se aplicaron algunas reformas fundadas en razón, como por ejemplo, la reducción del número de Sociedades, solicitada por las más sesudas de ellas como paliativo inmediato de una situación crítica y anárquica y como medio de revigorizar las restantes? ¿Para no herir susceptibilidades? Este argumento no tiene fuerza, ya que se podía presentar la aplicación de esta disposición como la consecuencia natural y lógica de las informaciones recogidas. La concesión de unas cuantas condecoraciones o recompensas hubiera hecho pasar lo amargo de la providencia. Pero no se hizo ni intentó nada en este sentido. Por el contrario. En los años inmediatos precisamente, y sin ningún plan de conjunto aparente, se multiplicaron las creaciones de Sociedades, muchas de ellas en villas o lugares de reducida importancia y de corta po- 
blación. Así en 1787 y 1788, aprobó el Consejo los Estatutos y por lo tanto la erección de Cuerpos Patrióticos en Ávila, Motril, agullar DE LA Frontera, CONSTANTINA, MEdina DEL CAMPo, tordesillas, Trujiddo, yébenes, herRera de río Pisuerga, pUerto de santa maría, baena, alCalá de los gazules, vejer de la frontera, o sea en trece ciudades o villas en las que, haciendo una salvedad para Avila, no llegó nunca a cuajar ningún Cuerpo Patriótico duradero. Observación que ilustra una vez más y corrobora lo que habían pronosticado las Sociedades en sus informes. Todo pasó como si el Consejo se desentendiese de todo e incluso como si optase por la política de lo peor.

Esta reacción del Consejo nos lleva a formular otras posibles explicaciones. Sabía mejor que nadie el Consejo que sin su apoyo incondicional estaban condenadas las Sociedades a un papel modesto, aunque útil. E1 que se les asignaba en pocas palabras en la Real Cédula de fundación de 18 de noviembre de 1774, quedaba impreciso. En ella se alababa el Discurso sobre la Industria popular cuya doctrina consistía en erradicar la ociosidad y fomentar las manufacturas de la nación. Las Sociedades no tendrían otro objeto esencial: "promover la felicidad pública, desterrando la ociosidad y subrogando en su lugar la industria general de la Nación, a fin de que por virtud de ella, florezcan las buenas costumbres, el recogimiento de las familias, la verdadera caridad y amor de los próximos desvalidos». El plan de urgencia preveía el establecimiento de escuelas y hospicios en todos los sitios, pero la redacción de la Real Cédula conservaba una imprecisión general que permitía muchas interpretaciones.

Ahora bien: si las Sociedades nunca se desentendieron de aquella misión de difusión de las luces y de rescate del pueblo amorfo e inculto que mencionaba la Real Cédula, pronto rebasaron el rígido marco inicial que se les había señalado. Llevadas a analizar desde cerca las condiciones de vida de la sociedad que les rodeaba, desarrollaron su espíritu crítico y descubrieron muchos fallos del régimen, no ya de la administración loeal, sino del Gobierno central; repararon en los mecanismos constitucionales anticuados o caducados, en injusticias, errores, abusos, obstáculos de toda índole que comprometían la marcha del País hacia el progreso. Preocupados por la eficacia de su acción, denunciaron a menudo todos aquellos estorbos y hasta propusieron enmiendas y reformas. LA matritense, en particular, consultada muchísimas veces por el Consejo, hizo de organismo asesor de la Superioridad, sugiriéndole a menudo, después de madura reflexión y estudio detenido, cambios y medidas a adoptar. Otros Cuerpos Patrióticos, entre los más prestigiosos, ambicionarían un papel parecido 
para su provincia y se encontrarían tambiến ante la necesidad de señalar no pocas rectificaciones que operar en la legislación vigente. En una pala* bra, la tendencia natural de las Sociedades era ingerirse en los asuntos gubernativos ${ }^{81}$. Anhelaban tal vez desempeñar el cometido de la Junta de Mejoras concebida por Ward. Su postura resueltamente crítica, denunciadora de las debilidades y arcaísmos del régimen, su afán reformador, su amor a la filosofía y a la razón, sus aspiraciones políticas, entrañaban ciertamente algún peligro para una mente conservadora. Las Sociedades eran dificiles de amordazar y las novedades que pretendían instaurar no eran del agrado de todos. Por su naturaleza democrática, su espíritu de independencia y de libertad, podían hacer vacilar sobre sus bases la vieja sociedad jerarquizada, con sus estamentos rigidos, sus fueros e intereses creados.

Pero, privadas de protección efectiva, aunque siempre teóricamente respaldadas por el Gobierno y el monarea, quedarian inofensivas. Pronto se calmarian sus impaciencias, pronto se apagarian sus brios y sus energias terminarian por agotarse en luchas estériles, en intentos fallidos. El Consejo sería el escollo en el que vendrian a romperse sus peligrosas embestidas al antiguo régimen. Quizá logró Campomanes convencer privadamente a Carlos III de aquella amenaza y de acuerdo con él, decidió dar carpetazo al asunto.

El silencio de Campomanes puede encontrar una explicación en este tipo de preocupaciones y recelos. Creyendo vislumbrar en los Cuerpos Eco-

8) No oculta la Matriteme qun desen establecer un sislema y una doetrina coherente y unifome. La Gase de Agricultura arremate contra mlos leyes que hacian jnevitables los abusosw. $y$ se propone sarrancar de rais unos males envejecidos quo tenian su origen en la contlitución nisma, que fortificaban las leyes y que el tiempo habia locho habitunles e incurables\%. La acción de la Clase de Industria se ejeree tamlyén en al eampo do la legislación. Propugna el arregle de las ordenatoas gremiales nutieuadas, la supresión del estanco y monopolio. La Clase de Artes y Oficios ha beupado 8 años (1777-1785) preparando toda una serie de mofornies de ordenanzas de varias entidades y corpornciones. Proyecta la disolución todal de los fromios y otraf medidas tan radicaleg.

Esta palpable ingereneis de la Matritenso en asuntos quo son de la ineunabencia del Gobierno ticne imitadoros on otras Seciedndes: Oviedo, por cjomb̨lo, que sugiere la crea. ción en los Cuerpos Patrióticos de unos oficinls llamados Promotores, tienc miras diéntiens. Los promotores en efecto sorian unos agentes de las Sociedades encariados do de. numbiar los abusos prowocatos por los leyes, los privilegios, las osrruptelas y costumbres reprensibtes y do señalar los puntus dignos de reformad. Esti realidad, esta creación que. ria sistematizar una tendencia ya percemtitale, en mayor o menor grada, en todas las Sociedades. 
nómicos unos gérmenes o focos eventuales de disidencia, perjudiciales al equilibrio establecido, no permitió que levantasen el vuelo; prefirió cortarles las alas nacientes para quitarles toda nocividad. Y no será ocioso recordar que en aquellas fechas de 1786-1788, no había estallado todavía la Revolución francesa. A partir de 1790, como era de prever, irían creciendo las suspicacias hacia los Cuerpos Patrióticos. La multiplicación de Sociedades, que, a modo de respuesta, se verificó a raíz y en contra del dictamen de los Fiscales, obedecería, en esta óptica, al deseo de no variar nada de lo ideado en un principio. Desparramando un sin fin de Sociedades por todo el territorio, se impediría el aumento de poder y de fuerzas que resultaría de la concentración de las mismas en las capitales de provincias.

La reacción de Campomanes fue una reacción de prudencia y de miedo ante el peligro que representa el progreso, porque, a la corta o a la larga, el progreso origina forzosamente una revolución de la sociedad. Campomanes se portó, en cierto modo, como el aprendiz de brujo que se atemoriza al ver la obra salida de sus manos. Se puede también interpretar su silencio como una advertencia y amonestación para las Sociedades. Les da asi a entender que no han de intentar salir de sus estrictas atribuciones, delimitadas en la Real Cédula de 1774 en cuanto a área de acción y móviles. Cerrándose a todo diálogo, borró Campomanes las ilusiones y aspiraciones de las Sociedades y deliberadamente las volvió a acantonar en el papel que había definido la cédula de su creación ${ }^{82}$.

En resumidas cuentas, la experiencia de las Sociedades Económicas de Amigos del País fue una experiencia frustrada y truncada. No pudo vivirse realmente, plenamente, tal como lo deseaban y ambicionaban sus indivi-

82 Para la Matritense, sin embargo, algo se hizo. Primero sabemos que los Fiscales reconocieron oficialmente en 1788 sus numerosos méritos o servicios, proclamando que por su incesante y fecunda actividad debía lavarse por completo de la nota de decadente. Obtuvo pues la Matritense esta apreciable satisfacción moral. Pero además, se vio aliviada de sus abrumadoras tareas por la constitución, en octubre de 1787, de una Junta de Damas, unida a la Real Sociedad, que asumió todos los problemas relativos, a la promoción de la mujer del pueblo, cargó con las Escuelas Patrióticas y se anexionó más tarde amplios sectores de la beneficencia madrileña, como la Inclusa y la Casa de los Desamparados. Campomanes había sido siempre partidario de la inclusión de las mujeres en la Sociedad Matritense, y había defendido su postura en un discurso que pronunció en la Junta de 18 de noviembre de 1775. Otros oradores, como es sabido, se habían mostrado favorables a la incorporación de señoras a lo largo de años sucesivos, pero hubieron de transcurrir doce antes de conseguirse la victoria. No es imposible que Campomanes haya influido en este feliz desenlace. 
duos, porque no se les otorgaron las estructuras y los auxilios que necesitaban y que hubieran garantizado su eficacia. El Gobierno no puso las Sociedades en condiciones de dar todo lo que de ellas se podía lógica y legítimamente esperar. Ya en 1765, el conde de Peñaflorida, en el discurso preliminar que pronunció en vergara, tenía aguda conciencia de la dependencia estrecha, factor de éxito o de fracaso, en que estarian respecto del Consejo. “No harán estos Cuerpos grandes progresos en la práctica, si no se hallan sostenidos por un Gobierno iluminado, cuyo supremo poder las haga triunfar de todos los obstáculos que se oponen a su ejecución». Y por su parte, haciéndose eco de estas palabras proféticas, avisaba el Censor de LA MATRITENSE, once años después, en su informe a la Sociedad: «Si las providencias del Gobierno no corresponden a lo que generalmente representa la Sociedad, no dudo en pronosticar su ruina, porque su existencia será tan lánguida, tan poco concurridas las juntas, tan sin actividad los trabajos, que pueden considerarse como no existentes».

No se suprimieron ni desaparecieron en el acto las Sociedades Económicas. Siguieron toleradas, pero vigiladas. No lograron cambiar radicalmen* te la faz de España. Pocas de sus ideas reformistas fueron recogidas y en este punto, pues, fracasaron. No logrando que las miras del Gobierno coincidiesen con las suyas, se resignaron a trabajar en los sectores de relativa envergadura que señalaba la Real Cédula de 1774. Realizaron en aquellos terrenos una labor fecunda, hasta admirable, pero estrictamente limitada al ámbito de su jurisdicción. Sus ambiciones de trabajar a nivel nacional, o por lo menos, a nivel provincial, quedaron en ciernes y se vieron definitivamente segadas por la actitud negativa del Gobierno en 1788 .

En este contexto, resulta fácil establecer una primera línea divisoria en la historia de las Sociedades Económicas. De 1775 a 1786, ponen a prueba el sistema ideado por Campomanes, se dan cuenta de sus imperfecciones, chocan con diversos obstáculos que retrasan su acción y hasta la paralizan en muchas ocasiones. Deseosas de más eficacia, aprovechan la encuesta de 1786 para expresar sus quejas y pretensiones, proponiendo una serie de reformas susceptibles de darles nuevo impulso. Todavía en aquellas fechas esperan ver satisfechas algunas de sus reivindicaciones y mejorada su situación. Confían en que el Gobierno corresponderá a su anhelo de utilidad con una mayor confianza. El silencio del Consejo en 1788 arruina sus aspiraciones y reduce el campo de sus actividades. Desde entonces, seguirán trabajando sin ilusiones, y sabemos que los acontecimientos políticos posteriores no depararán a las Sociedades ninguia nueva oportunidad 
de poner por obra el amplio y generoso programa de renovación, de prosperidad nacional y felicidad pública con que habían soñado para su patria.

Jorge Demerson

Paula de Demerson

A P E N D I C E

\section{LISTA DE LOS FIRMANTES DE LOS INFORMES CITADOS EN ESTE TRABAJO}
Alaejos
D. Atanasio León Ballesteros, Director.
D. Manuel Méndez Prado, Secretario.
D. Pedro Guerrero.
D. Manuel Pérez Sandonis, Comisionado.
Baeza
D. Antonio Ponce de León y Galeote, Director.
D. Antonio de Quadros, ex-Director.
D. Andrés de la Fontecilla, Consiliario.
D. Vicente Pablo de Olid, Consiliario.
D. Fernando de Viedma, Consiliario.
El marqués de San Miguel de la Vega, Secretario.
Baza D. Pedro Pablo de Castro, Director.
D. Antonio Josef Navarro, Secretario.
Gran Canaria Doctor D. Luis de la Encina, Vice-Director.
Doctor D. Jerónimo De Roo y Fonte, Censor.
D. Pedro Russell, Secretario.
Ciudad Rodrigo D. Antonio Corbalán y Castro, Director.
D. Nicolás Martín Grande, Vice-Director.
Cuenca D. Juan Nicolás Alvarez de Toledo, Vice-Director.
D. Pascual Alvarez de Toledo, Secretario.
Granada D. Antonio Pérez de Herrasti, Sub-Director.
D. Gutierre Vaca de Guzmán, Censor.
D. Florentín del Pulgar, Secretario.
Conde de Villa Amena, Contador.
D. Juan Mariño.

Jerez de la Frontera Marqués de Villapanés, Director. 


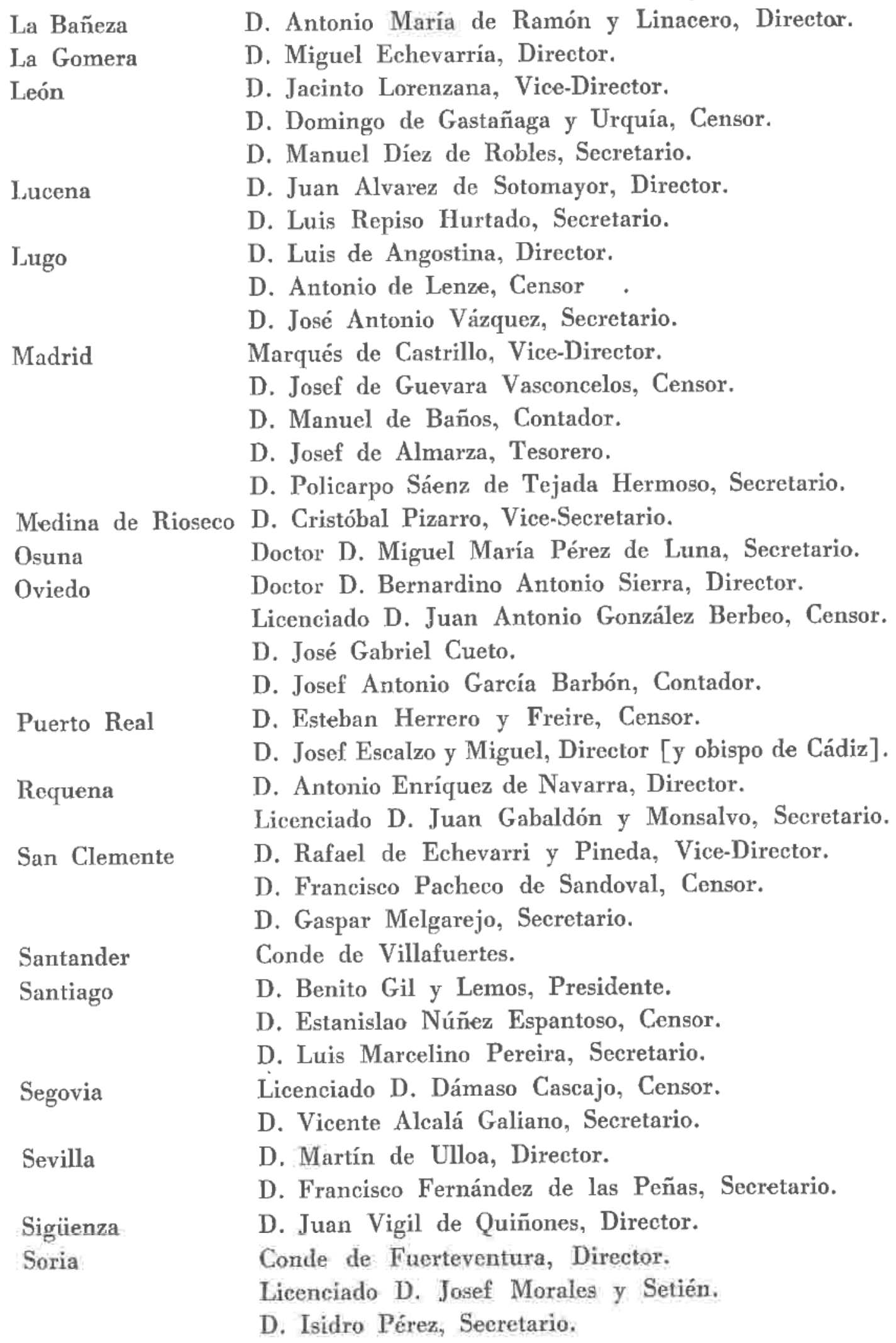


Toledo

D. Josef Lorenzana, Director.

D. Hilario de Peñalver, Vice-Director.

D. Pedro Vélez Salcedo Palomeque, Secretario.

Tudela

D. Felipe González de Castejón, Director.

Valladolid

Marqués de San Adrián, Secretario.

Valladolid

D. Germán de Salcedo, Director.

Vélez Málaga

D. Juan de Dios de Nuevas, Secretario.

D. Francisco Larrachea, Vice-Director.

D. Julián Coronado, Censor.

D. Antonio Pérez Dávila, Secretario.

Vera D. Diego Antonio Carbonell del Rosal, Director.

D. Francisco de Casa Leiz, Secretario.

Vergara

Marqués de Montehermoso, Director.

Yepes

D. Juan Bautista Porcel, Vice-Secretario.

Zamora

D. Josef Hernando de Soto, Director.

D. Marcos Antonio de Villafañe, Director.

D. Vicente de Guadalfexara, Secretario.

Zaragoza

D. Arias Antonio Mon y Velarde, Director.

D. Diego de Torres, Secretario. 